\title{
Radial Deconsolidation and Leach-Burn-Leach of AGR-3/4 Compacts 8-4 and 7-4
}

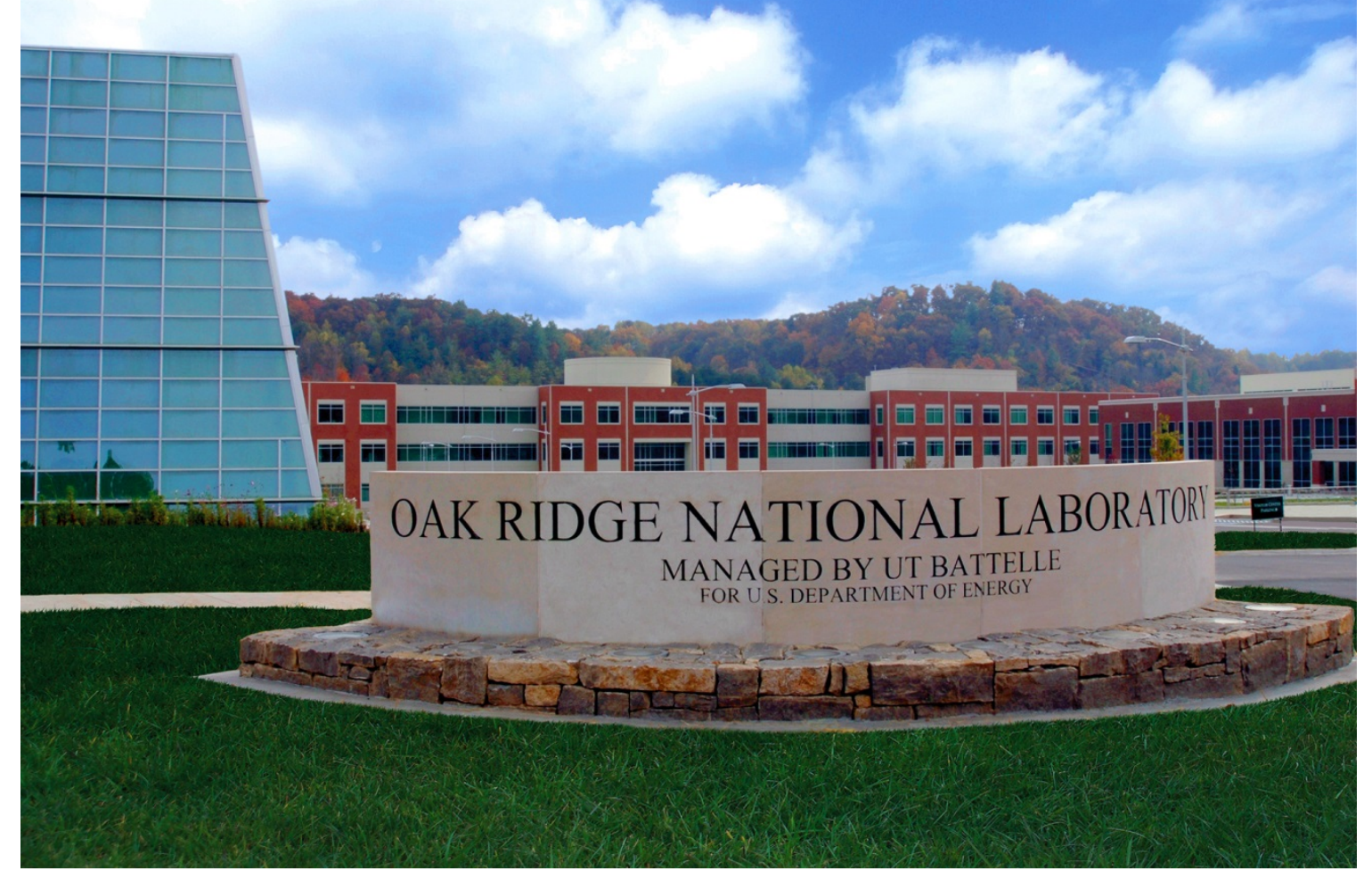

Grant W. Helmreich John D. Hunn Fred C. Montgomery Darren J. Skitt

September 2021 


\title{
DOCUMENT AVAILABILITY
}

Reports produced after January 1, 1996, are generally available free via US Department of Energy (DOE) SciTech Connect.

Website www.osti.gov

Reports produced before January 1, 1996, may be purchased by members of the public from the following source:

\author{
National Technical Information Service \\ 5285 Port Royal Road \\ Springfield, VA 22161 \\ Telephone 703-605-6000 (1-800-553-6847) \\ TDD 703-487-4639 \\ Fax 703-605-6900 \\ E-mail info@ntis.gov \\ Website http://classic.ntis.gov/
}

Reports are available to DOE employees, DOE contractors, Energy Technology Data Exchange representatives, and International Nuclear Information System representatives from the following source:

Office of Scientific and Technical Information

PO Box 62

Oak Ridge, TN 37831

Telephone 865-576-8401

Fax 865-576-5728

E-mail reports@osti.gov

Website https://www.osti.gov/

This report was prepared as an account of work sponsored by an agency of the United States Government. Neither the United States Government nor any agency thereof, nor any of their employees, makes any warranty, express or implied, or assumes any legal liability or responsibility for the accuracy, completeness, or usefulness of any information, apparatus, product, or process disclosed, or represents that its use would not infringe privately owned rights. Reference herein to any specific commercial product, process, or service by trade name, trademark, manufacturer, or otherwise, does not necessarily constitute or imply its endorsement, recommendation, or favoring by the United States Government or any agency thereof. The views and opinions of authors expressed herein do not necessarily state or reflect those of the United States Government or any agency thereof. 
Nuclear Energy and Fuel Cycle Division

\title{
RADIAL DECONSOLIDATION AND LEACH-BURN-LEACH OF AGR-3/4 COMPACTS 8-4 AND 7-4
}

\author{
Grant W. Helmreich \\ John D. Hunn \\ Fred C. Montgomery \\ Darren J. Skitt
}

September 2021

\begin{abstract}
Work sponsored by US DEPARTMENT OF ENERGY

Office of Nuclear Energy-Advanced Reactor Technologies under the
\end{abstract}

Advanced Gas Reactor Fuel Development and Qualification Program

Prepared by

OAK RIDGE NATIONAL LABORATORY

Oak Ridge, TN 37831-6283

managed by

UT-BATTELLE LLC

for the

US DEPARTMENT OF ENERGY

under contract DE-AC05-00OR22725 



\section{CONTENTS}

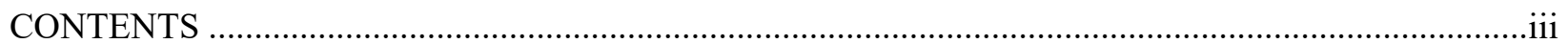

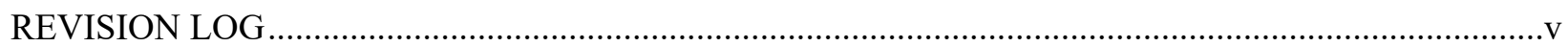

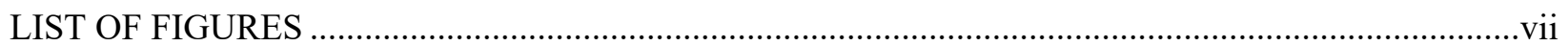

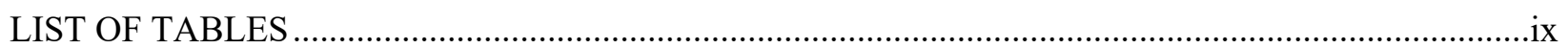

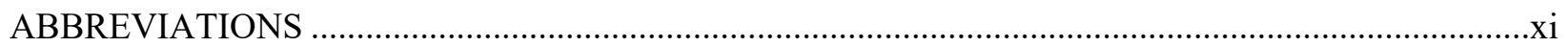

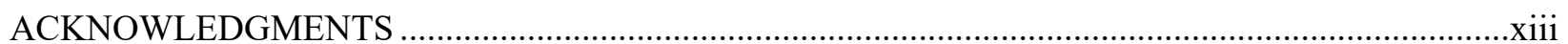

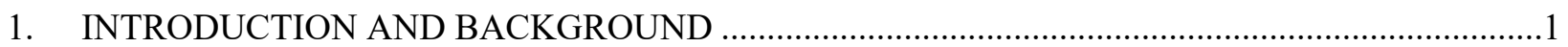

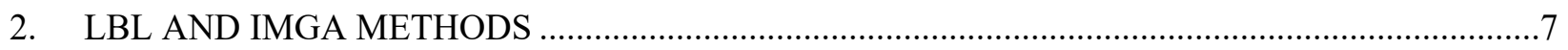

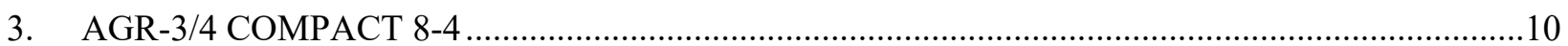

3.1 Radial Deconsolidation and Dimensional Analysis of Compact 8-4

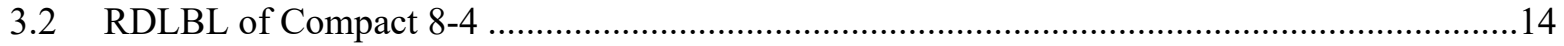

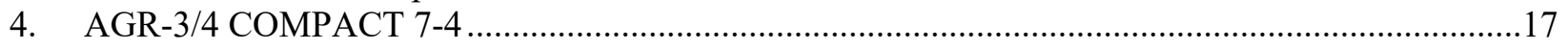

4.1 Radial Deconsolidation and Dimensional Analysis of Compact 7-4 ....................................17

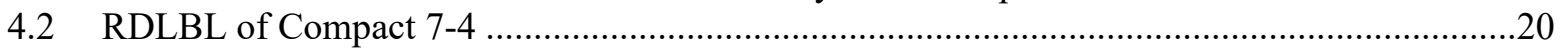

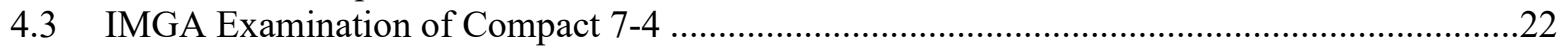

5. DISCUSSION OF RESULTS FOR AGR-3/4 COMPACTS 1-4, 7-4, AND 8-4 ..........................24

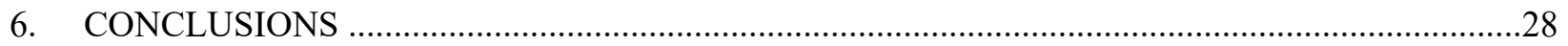

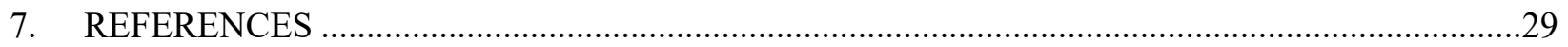

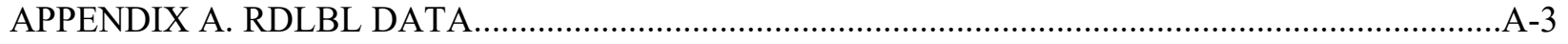

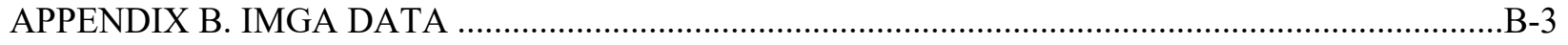

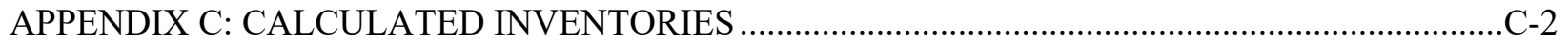

APPENDIX D: SPECIAL DECONSOLIDATION APPARATUS …….............................................. 



\section{REVISION LOG}

\begin{tabular}{cccc}
\hline Revision & Date & Affected pages & Revision description \\
\hline 0 & All & Initial issue & \\
& & \\
& & \\
& & \\
\hline
\end{tabular}





\section{LIST OF FIGURES}

Figure 1-1. X-ray radiographs of $2.5 \mathrm{~mm}$ sections from four AGR-3/4 compacts; DTF particles

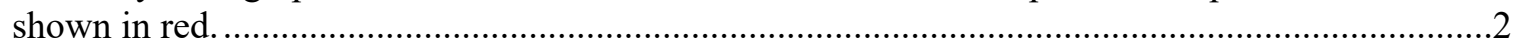

Figure 1-2. Radial deconsolidation rig in raised position for imaging and beaker exchange........................

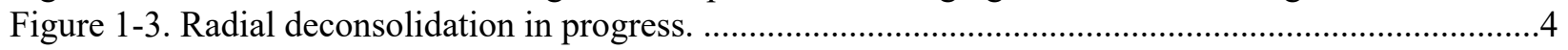

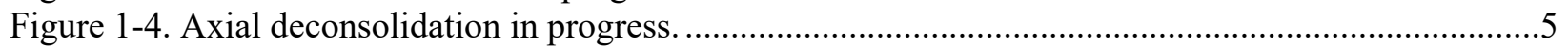

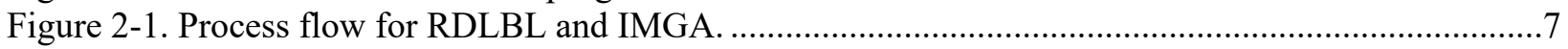

Figure 3-1. Compact 8-4 at each stage of radial deconsolidation........................................................11

Figure 3-2. Compact 8-4 before radial deconsolidation with calibration block. ........................................12

Figure 3-3. Examples of Compact 8-4 automated photo analysis at each stage of radial

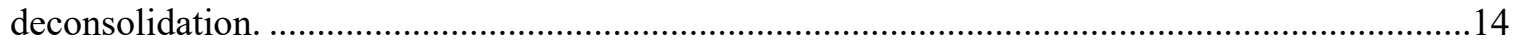

Figure 3-4. Distribution of ${ }^{144}$ Ce from DTF particles in Compact 8-4 ..................................................16

Figure 4-1. Compact 7-4 at each stage of radial deconsolidation.....................................................18

Figure 4-2. Examples of Compact 7-4 automated photo analysis at each stage of radial

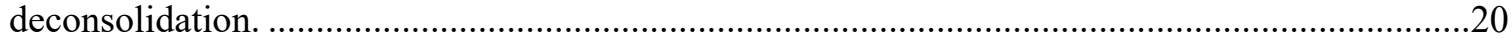

Figure 4-3. Distribution of ${ }^{144} \mathrm{Ce}$ from DTF particles in Compact 7-4 ..............................................22

Figure 4-7. Measured vs. calculated ${ }^{137} \mathrm{Cs}$ activity in 1,829 particles from AGR-3/4 Compact 7-4..........23

Figure 5-1. Comparison of ${ }^{144} \mathrm{Ce},{ }^{235} \mathrm{U}$, and ${ }^{239} \mathrm{Pu}$ diffusion from DTF particles in Compact 8-4.............25

Figure 5-2. Comparison of ${ }^{144} \mathrm{Ce},{ }^{137} \mathrm{Cs},{ }^{154} \mathrm{Eu}$, and ${ }^{90} \mathrm{Sr}$ diffusion from DTF particles in

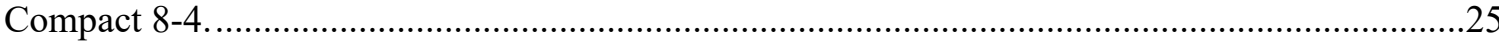

Figure 5-3. Comparison of ${ }^{144} \mathrm{Ce},{ }^{235} \mathrm{U}$, and ${ }^{239} \mathrm{Pu}$ diffusion from DTF particles in Compact 7-4.............26

Figure 5-4. Comparison of ${ }^{144} \mathrm{Ce},{ }^{137} \mathrm{Cs},{ }^{154} \mathrm{Eu}$, and ${ }^{90} \mathrm{Sr}$ diffusion from DTF particles in Compact 7-4.

Figure 5-5. Comparison of ${ }^{144} \mathrm{Ce},{ }^{137} \mathrm{Cs}$, and ${ }^{154} \mathrm{Eu}$ diffusion from DTF particles in Compact 1-4. Reproduced from (Hunn et al. 2020).

Figure 5-6. Comparison of ${ }^{144} \mathrm{Ce},{ }^{235} \mathrm{U}$, and ${ }^{239} \mathrm{Pu}$ diffusion from DTF particles in Compact 1-4. Reproduced from (Hunn et al. 2020). 



\section{LIST OF TABLES}

Table 1-1. Irradiation and safety test parameters for AGR-3/4 compacts analyzed in this study................6

Table 3-1. Equal volume segment plan for Compact 8-4 …............................................................10

Table 3-2. Segment results for Compact 8-4 measured with automated photo analysis ............................10

Table 3-3. Raw and adjusted calibration values in pixels $/ \mathrm{mm}$ used for Compact 8-4 image

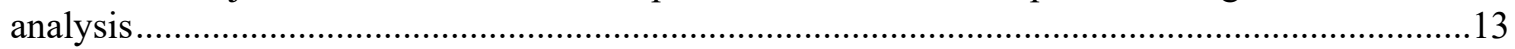

Table 3-4. Comparison of particle-equivalents of select nuclides in Compact 8-4 segments ......................15

Table 3-5. Particle-equivalents of ${ }^{144} \mathrm{Ce}$ detected in Compact 8-4 RDLBL solutions ................................15

Table 4-1. Equal volume segment plan for Compact 7-4 …..................................................................17

Table 4-2. Segment results for Compact 7-4 measured with automated photo analysis ...........................17

Table 4-3. Raw and adjusted calibration values in pixels $/ \mathrm{mm}$ used for Compact 7-4 image

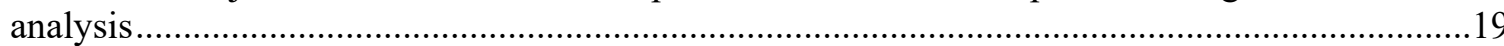

Table 4-4. Comparison of particle-equivalents of select nuclides in Compact 7-4 segments ....................21

Table 4-5. Particle-equivalents of ${ }^{144} \mathrm{Ce}$ detected in Compact 7-4 RDLBL solutions ................................21

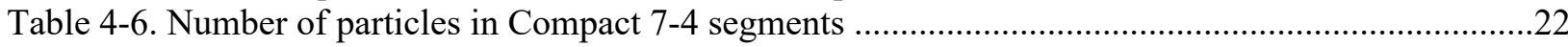

Table 4-7. Statistical summary of Compact 7-4 driver fuel particle activities ........................................23 



\begin{tabular}{ll} 
& \multicolumn{1}{c}{ ABBREVIATIONS } \\
AGR & Advanced Gas Reactor (Fuel Development and Qualification Program) \\
AGR-1 & first AGR program irradiation experiment \\
AGR-2 & second AGR program irradiation experiment \\
AGR-3/4 & third and fourth AGR program irradiation experiments \\
RDLBL & radial deconsolidation and leach-burn-leach \\
DTF & designed-to-fail (fuel particle) \\
EOL & end of life \\
FB-CVD & fluidized-bed chemical vapor deposition (coating system) \\
FIMA & fissions per initial metal atom \\
ID & identification \\
INL & Idaho National Laboratory \\
IMGA & Irradiated Microsphere Gamma Analyzer \\
LBL & leach-burn-leach \\
JMOCUP & Jim's MCNP-ORIGEN2 Coupled Utility Program \\
M/A & measured vs. average \\
M/AA & measured vs. adjusted average measured \\
M/C & measured vs. calculated \\
MCNP & Monte Carlo N-Particle Transport code \\
ORIGEN & Oak Ridge Isotope Generation and Depletion code \\
ORNL & Oak Ridge National Laboratory \\
PIE & post-irradiation examination \\
RS & randomly selected (particles) \\
SD & standard deviation \\
SiC & silicon carbide (TRISO layer) \\
SP & special particle (abnormal particles typically identified with IMGA) \\
TA max $_{\text {TA }}$ & time-average maximum (temperature) \\
TAVA & time-average minimum (temperature) \\
TRISO & time-average, volume-average (temperature) \\
UCO & tristructural-isotropic (coated particles) \\
& uranium carbide and uranium oxide (fuel kernels) \\
&
\end{tabular}





\section{ACKNOWLEDGMENTS}

This work was sponsored by the US Department of Energy Office of Nuclear Energy Advanced Reactor Technologies as part of the Advanced Gas Reactor Fuel Development and Qualification Program. Analysis of leach solutions was conducted by the Oak Ridge National Laboratory (ORNL) Radioactive Materials Analytical Laboratory, including Tamara Keever, Charles Watson, Marc Chattin, and Haley Wightman. Hot cell activities were supported by ORNL Irradiated Fuels Examination Laboratory staff, including Caleb Dryman, John Hinds, and Scott Thurman. 


\section{INTRODUCTION AND BACKGROUND ${ }^{1}$}

The Advanced Gas Reactor (AGR) Fuel Development and Qualification Program's third and fourth irradiation experiments (AGR-3/4), originally planned as separate tests, were combined into one test train for irradiation in the Advanced Test Reactor at Idaho National Laboratory (INL). The irradiation test began on December 14, 2011, and ended on April 12, 2014 (Collin 2016). The originally planned AGR-3 and AGR-4 irradiation experiments were both to be focused on obtaining fission product transport data to support improvements in modeling. The AGR-3 experimental plan was focused on gaseous and metallic fission product release from the kernels and diffusion in the coatings during irradiation and postirradiation safety testing. The AGR-4 experimental plan was focused on diffusivities and sorptivities in the compact matrix and reactor graphite (Petti et al. 2005). These goals were combined in the AGR-3/4 irradiation experiment, which consisted of twelve independently monitored capsules that each contained four AGR-3/4 compacts in a single stack surrounded by an inner ring of matrix or graphite and an outer ring of graphite. There were two capsule types: a standard capsule and a fuel body, in which the outer graphite ring included a floor and cap to fully enclose the fuel (Stempien et al. 2018a). The fuel body design supported post-irradiation safety testing of the intact fuel and ring assembly to obtain data on fission product transport and release from matrix and graphite at accident temperatures (Demkowicz 2017).

The key feature of the AGR-3/4 compacts was the inclusion of 20 designed-to-fail (DTF) fuel particles distributed along the centerline of each compact. A summary of the AGR-3/4 irradiation test compact fabrication campaign has been published by Hunn et al. (2012). The DTF fuel particles and surrounding driver fuel particles were fabricated at Oak Ridge National Laboratory (ORNL) using a lab-scale fluidized-bed chemical vapor deposition (FB-CVD) coating system with a chamber inner diameter of $50 \mathrm{~mm}$. Kernels came from a single composite (G73V-20-69303) manufactured by BWX Technologies, which was upgraded by manual sorting to remove debris and irregularly shaped kernels. This composite was renamed $L E U 03$. The kernels contained both uranium carbide and uranium oxide phases (UCO) with an enrichment of $19.7 \%$, and they were similar to those used in the first AGR program irradiation experiment (AGR-1). Kernel diameter was nominally $350 \mu \mathrm{m}$, with a measured average value of $357.3 \mu \mathrm{m}$ and a standard deviation of $1.6 \mu \mathrm{m}$ (Kercher and Hunn 2006). The AGR-3/4 driver fuel particles were standard tristructural-isotropic (TRISO)-coated particles like those used in the AGR-1 experiment (Lowden 2006). Four coater batches were upgraded and combined into one composite (LEU03-09T). The TRISO particle batches and composite were thoroughly characterized, and they passed all specifications (Hunn and Lowden 2007). The DTF particles were produced in a single batch (LEU0307DTF) after an extensive development effort to ensure that the $20 \mu \mathrm{m}$ pyrolytic carbon coating met the specified properties. These properties were defined as a coating that is expected to fail during irradiation without failing prematurely during compact heat treatment up to $1,800^{\circ} \mathrm{C}$ (Kercher et al. 2011). The AGR-3/4 DTF and driver fuel particles were overcoated and pressed into the final cylindrical compact fuel form (nominally one-half inch in both diameter and length) using methods similar to those developed for fabrication of compacts made for the second AGR program irradiation experiment (AGR-2). However, new techniques were used for overcoating and distributing the DTF particles along the center line of the AGR-3/4 fuel compact. Overcoated DTF particles were imaged with x-ray radiography to verify that each overcoated particle contained exactly one DTF particle, and the overcoated particles were hand counted to ensure that each compact held exactly twenty DTF particles. Radiographs of $2.5 \mathrm{~mm}$ sections cut from the center of four AGR-3/4 compacts are shown in Figure 1-1. As shown in the figure, the compacts were sectioned so the radiography would show the DTF particles. The DTF particles were evenly distributed in the bottom three-quarters of the compact and within $\sim 1.3 \mathrm{~mm}$ of the compact

\footnotetext{
${ }^{1}$ This introduction section is a revised version of a similar section in a previous AGR-3/4 PIE report (Hunn and Montgomery, 2020) and is included herein with minor edits for contextual information and definition of terminology used throughout this report.
} 
centerline. The partial collapse of the linear stack of overcoated DTF particles was likely caused when the tube (used to hold the overcoated DTF in place while overcoated driver fuel particles are added) was removed. Thorough characterization of AGR-3/4 fuel compact composite determined that it conformed to all specifications (Hunn, Trammell, and Montgomery 2011). In addition to 20 DTF particles, each AGR-3/4 compact held an average of 1,898 driver fuel particles, based on a count of the particles deconsolidated from 18 randomly selected (RS) compacts.
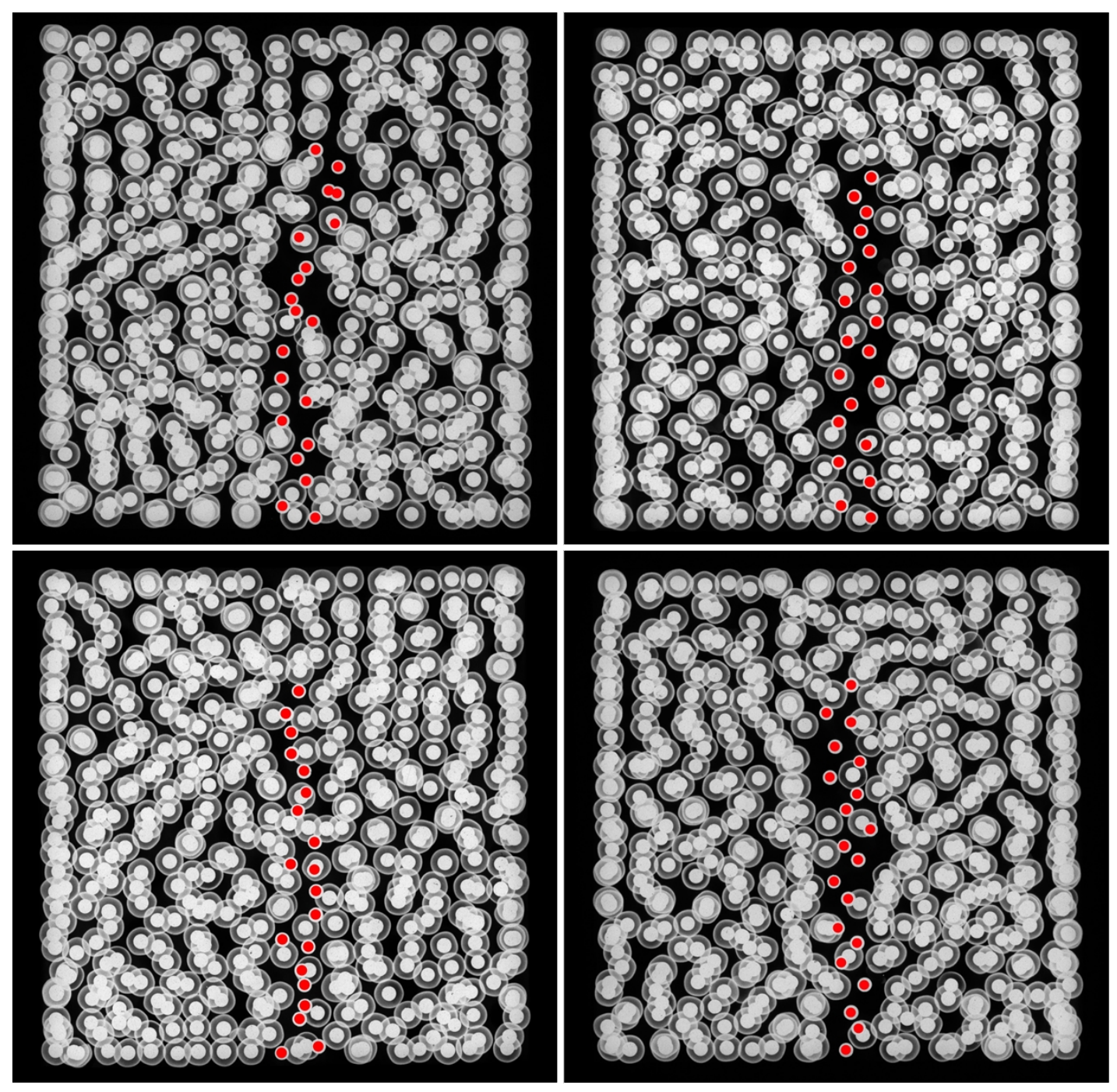

Figure 1-1. X-ray radiographs of $2.5 \mathrm{~mm}$ sections from four AGR-3/4 compacts; DTF particles shown in red.

Ongoing post-irradiation examination (PIE) of the AGR-3/4 compacts includes radial deconsolidation of individual compacts. This is done to segment the compacts into separate collections of particles and matrix debris from concentric cylindrical volumes. Each separate collection can be subjected to leachburn-leach (LBL) analysis to quantify the presence of actinides and fission products released by the driver fuel and DTF particles. Typically, three cylindrical rings of driver fuel particles and matrix are removed, leaving a cylindrical core encompassing the DTF particles. The core section is then axially deconsolidated. Initial development and testing of the radial deconsolidation process were accomplished using unirradiated AGR-3/4 compacts (Helmreich, Montgomery, and Hunn 2015), and then the concept was modified for deconsolidation of irradiated AGR-3/4 compacts in the INL hot cells (Stempien 2017). Detailed information on the process and equipment can be obtained from the referenced reports. 
Radial deconsolidation of irradiated AGR-3/4 compacts began at ORNL in 2020. Excess equipment from the development of the INL hot cell rig was shipped to ORNL and assembled for use at ORNL with minor modifications (Figure 1-2-Figure 1-4). Notably, a 20 mil shim $(0.5 \mathrm{~mm})$ was inserted between the sample holder and drive support bracket to reduce wobble of the compact and rod during rotation, and a slot was cut in the beaker opposite the spout so the required level of the nitric acid was lower, which made it easier to pick up the beaker without spilling acid. Deconsolidation was performed using $6 \mathrm{~mol} / \mathrm{L}$ nitric acid, and current was controlled at $0.8 \mathrm{~A}$ for the radial deconsolidation or $0.35 \mathrm{~A}$ for the axial deconsolidation (direct current voltage was typically around $5 \mathrm{~V}$ ).

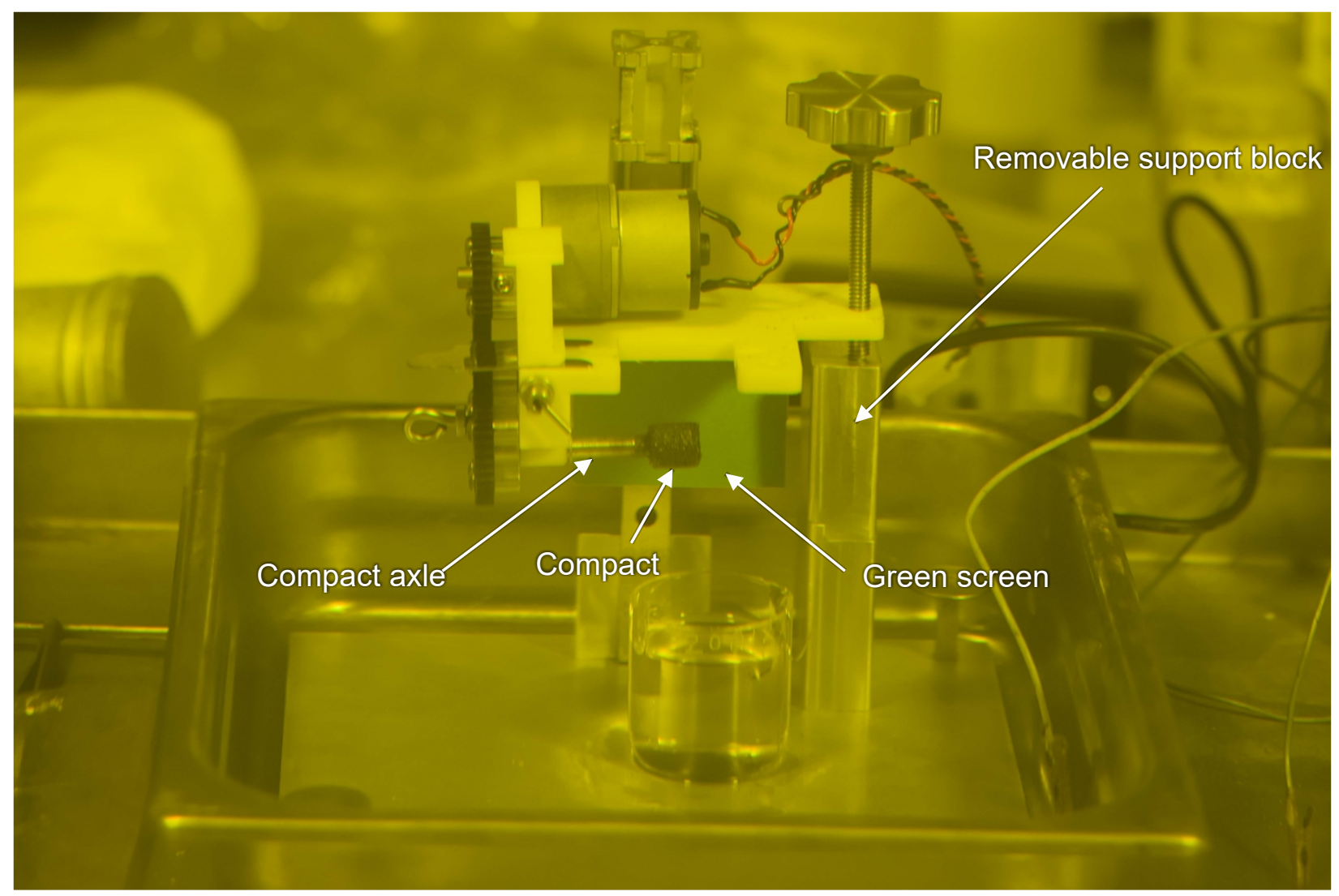

Figure 1-2. Radial deconsolidation rig in raised position for imaging and beaker exchange. 


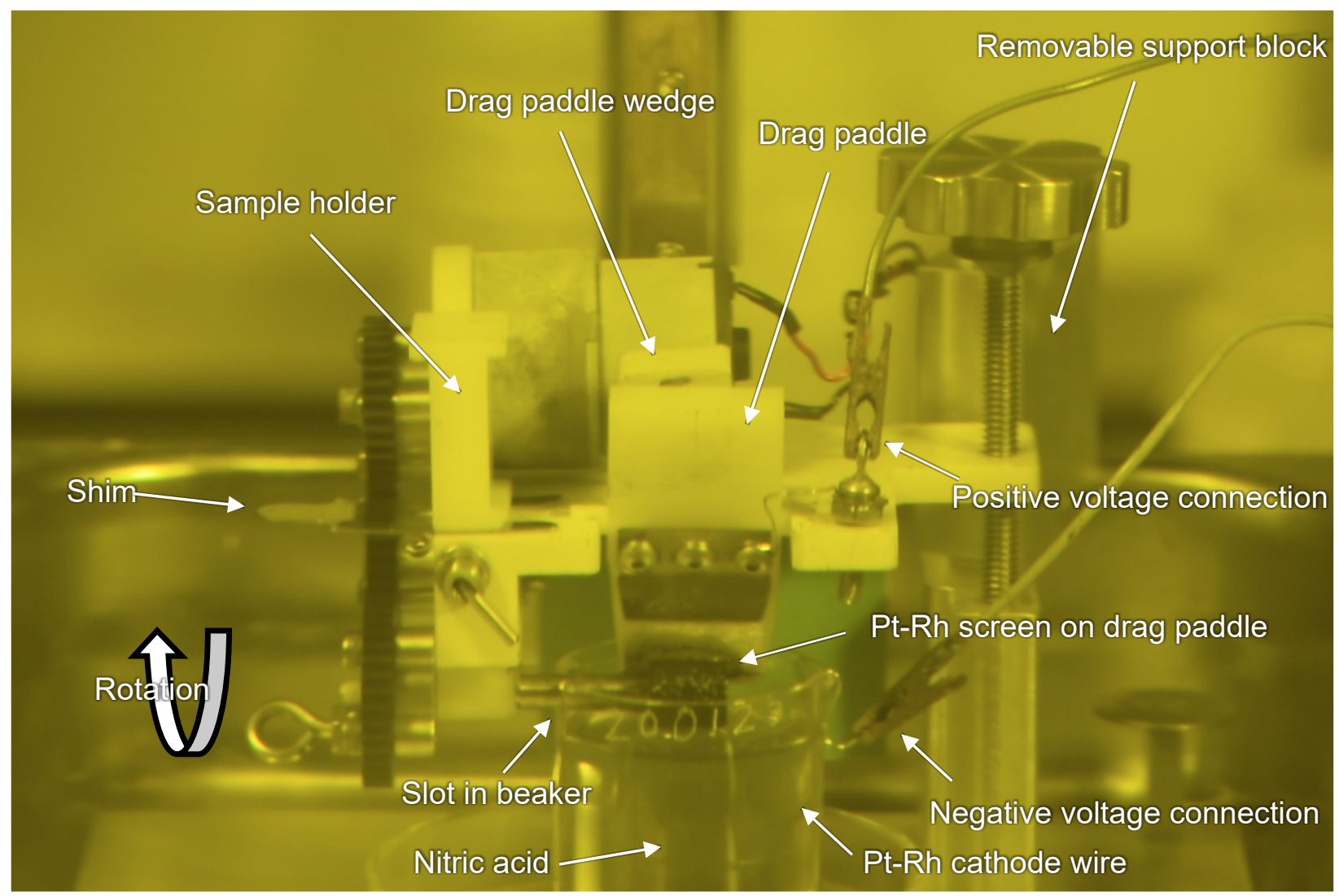

Figure 1-3. Radial deconsolidation in progress. 


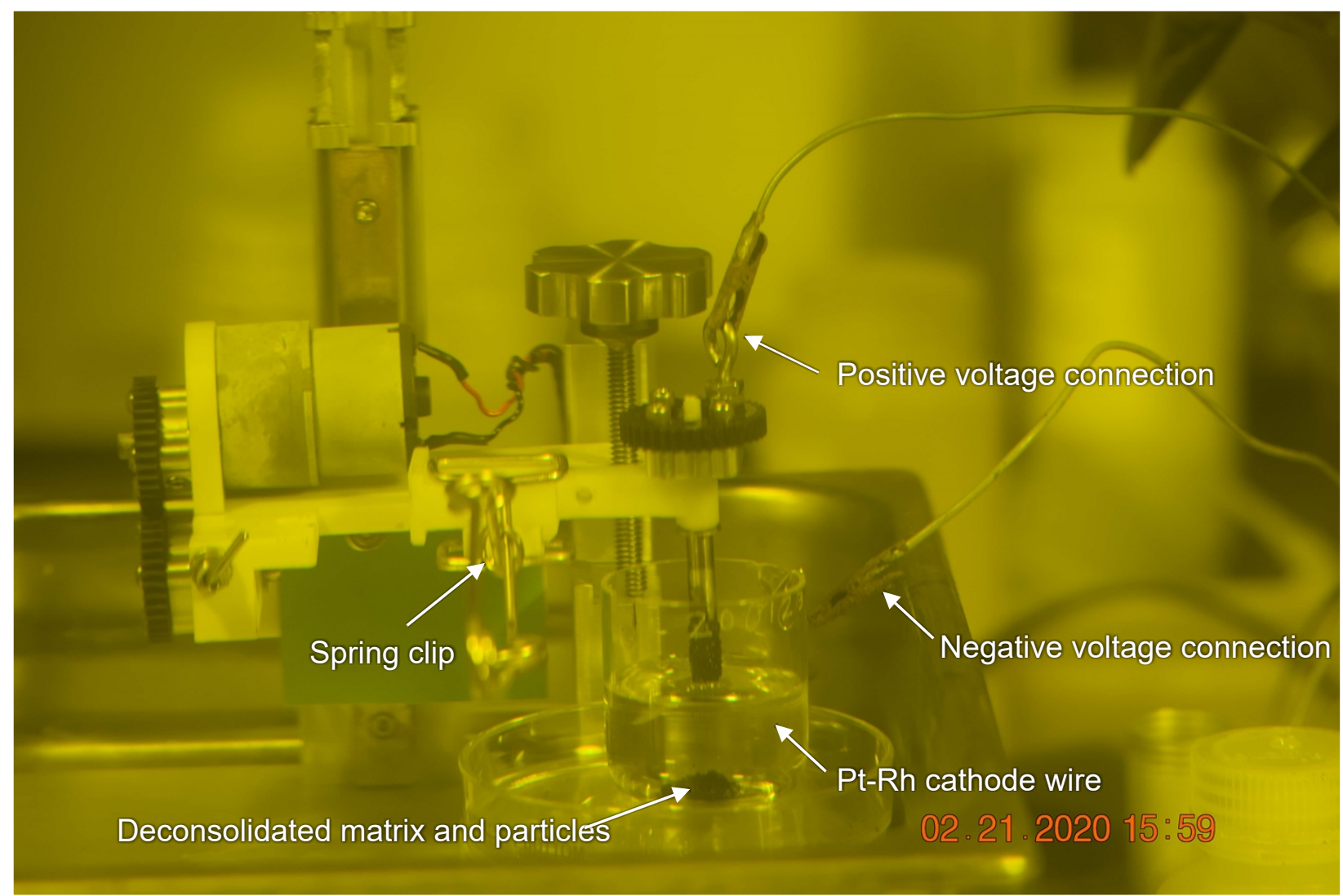

Figure 1-4. Axial deconsolidation in progress.

The AGR-3/4 compacts were irradiated to average calculated burnups of 4.85-15.27\% fissions per initial metal atom (FIMA), and the average calculated fluences of fast neutrons with energies $\mathrm{E}_{\mathrm{n}}>0.18 \mathrm{MeV}$ were 1.19-5.32 $\times 10^{25} \mathrm{n} / \mathrm{m}^{2}$ (Sterbentz 2015). The calculated time-average, volume-average (TAVA) compact temperatures ranged between $832-1,376^{\circ} \mathrm{C}$ (Hawkes 2014). Table 1-1 shows the calculated irradiation conditions for two compacts that were subjected to radial deconsolidation and LBL (RDLBL) at ORNL. Both compacts were irradiated in standard (not fuel body) capsules. Compact 8-4 experienced burnup and temperatures near the upper end of the ranges for compacts in the AGR-3/4 irradiation test. Compact 7-4 experienced irradiation burnup and temperatures at the top of the ranges for compacts in the AGR-3/4 irradiation test (Stempien et al. 2018b). 
Table 1-1. Irradiation and safety test parameters for AGR-3/4 compacts analyzed in this study

\begin{tabular}{|c|c|c|c|c|c|c|c|}
\hline \multirow{2}{*}{ Compact ID $^{a}$} & \multirow{2}{*}{$\begin{array}{l}\text { Fabrication } \\
\text { ID number }{ }^{b}\end{array}$} & \multirow{2}{*}{$\begin{array}{c}\text { Safety test } \\
\left({ }^{\circ} \mathbf{C}\right)\end{array}$} & \multirow{2}{*}{$\begin{array}{c}\text { Burnup }^{c} \\
\text { (\% FIMA) }\end{array}$} & \multirow{2}{*}{$\begin{array}{l}\text { Fast fluence }{ }^{c} \\
\qquad\left(\mathbf{n} / \mathbf{m}^{2}\right)\end{array}$} & \multicolumn{3}{|c|}{ Temperature $^{d}\left({ }^{\circ} \mathrm{C}\right)$} \\
\hline & & & & & TAVA & $\mathbf{T} \mathbf{A}_{\min }$ & $\mathbf{T} \mathbf{A}_{\max }$ \\
\hline AGR-3/4 Compact 8-4 & $\mathrm{Z} 120$ & none & 14.43 & $5.02 \times 10^{25}$ & 1169 & 1068 & 1242 \\
\hline AGR-3/4 Compact 7-4 & Z111 & none & 14.90 & $5.24 \times 10^{25}$ & 1319 & 1206 & 1397 \\
\hline
\end{tabular}

${ }^{a}$ The compact identification (ID) denotes the compact's location in the irradiation test train: capsule-level (Collin 2015).

${ }^{b}$ Each compact in the fabrication lot (LEU03-10T-OP2/LEU03-07DTF-OP1)-Z had a unique compact ID number ranging from 001-175, and physical properties data are available and referenced by compact ID number (Hunn, Trammell, and Montgomery, 2011).

${ }^{c}$ Compact average burnups and fast neutron fluences $\left(\mathrm{E}_{\mathrm{n}}>0.18 \mathrm{MeV}\right)$ are based on daily depletion calculations (Sterbentz 2015).

${ }^{d}$ Compact TAVA, time-average minimum $\left(\mathrm{TA}_{\min }\right)$ and time-average maximum $\left(\mathrm{TA}_{\max }\right)$ temperatures are based on thermal calculations (Hawkes 2016). 


\section{LBL AND IMGA METHODS²}

After radial deconsolidation, LBL and gamma scanning of individual particles were performed using the same methods that were developed for destructive PIE of as-irradiated AGR-1 compacts, and the details of the equipment and methods have been previously reported (Hunn et al. 2013). Figure 2-1 is a flow diagram of the typical process for compact RDLBL integrated with gamma survey of the particle inventory using the ORNL Irradiated Microsphere Gamma Analyzer (IMGA). Deconsolidation and leach solutions were analyzed by gamma and mass spectrometry, which provided information about actinides and fission products that were not sealed inside retentive SiC layers. Results are expected to be dominated by actinides and fission products from the 20 DTF particles in each AGR-3/4 compact. However, actinides and fission products leached in the deconsolidation acid, preburn Soxhlet extractions of the particles and matrix, pot boil of the particles and matrix, and postburn pot leaches of the matrix may have also come from (1) uranium outside the $\mathrm{SiC}$ in the as-fabricated compacts, (2) diffusion through the driver fuel $\mathrm{SiC}$ layers during irradiation or safety testing, and/or (3) exposed kernels in driver fuel particles with failed TRISO. In addition, actinides and fission products leached in the postburn Soxhlet extractions of the particles may have come from (1) exposed kernels in driver fuel particles with failed $\mathrm{SiC}$ and/or (2) diffusively released actinides and fission products that were not leached prior to the burn because they were previously sequestered in a pyrolytic carbon layer or in an insoluble chemical form.

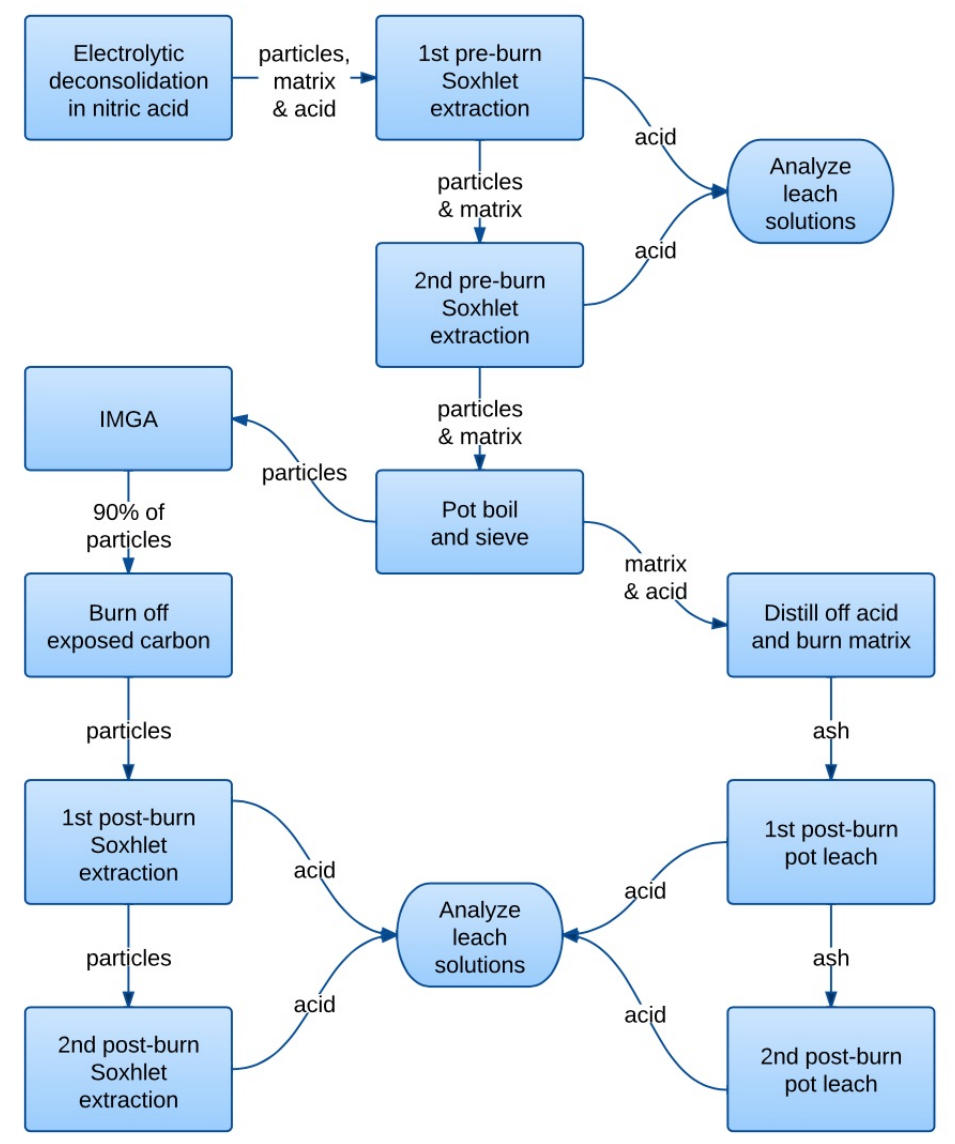

Figure 2-1. Process flow for RDLBL and IMGA.

\footnotetext{
${ }^{2}$ This experimental methods section is a revised version of a similar section in a previous AGR-2 PIE report (Hunn et al. 2020), and is included herein with minor edits for contextual information and definition of terminology used throughout this report.
} 
Actinide and fission product measurements were converted to fractions of the total compact inventory, or compact fraction, using the standard ORNL AGR PIE approach (Hunn et al. 2013), which involved dividing by the calculated inventory. The calculated total inventory of each nuclide was estimated using physics calculations (Sterbentz 2015) and reported at three specific times after the end of the irradiation, also called the end of life (EOL): namely, one day after EOL, one year after EOL, and two years after EOL. Radionuclide quantities measured by gamma spectrometry (e.g., ${ }^{106} \mathrm{Ru},{ }^{110 \mathrm{~m}} \mathrm{Ag},{ }^{125} \mathrm{Sb},{ }^{134} \mathrm{Cs},{ }^{137} \mathrm{Cs}$, ${ }^{144} \mathrm{Ce},{ }^{154} \mathrm{Eu}$, and ${ }^{155} \mathrm{Eu}$ ) — or chemical separation and beta spectrometry in the special case of ${ }^{90} \mathrm{Sr}$ - were decay-corrected to one day after EOL and divided by the calculated total inventory at that time to determine the compact fraction. For stable nuclides and actinides (e.g., ${ }^{235} \mathrm{U},{ }^{236} \mathrm{U},{ }^{238} \mathrm{U},{ }^{239} \mathrm{Pu}$, and ${ }^{240} \mathrm{Pu}$ ), the measured quantity was divided by the calculated total inventory at one year after EOL. This was done because radionuclide decay generated additional actinide and stable nuclides over the first year after the compacts were removed from the reactor, whereas any further increase in the calculated total inventories after one year was typically negligible. The mass spectrometry analysis was almost always performed after one year based on the time required for the test train to cool down and be disassembled. Results were also calculated, and are typically presented, in terms of the equivalent particle inventory or the number of particle-equivalents, which is defined as the compact fraction multiplied by the average number of particles per compact: 1,918 for AGR-3/4 compacts (Hunn, Trammell, and Montgomery 2011).

The IMGA data are reported herein as activities in Bq/particle that were decay-corrected to one day after EOL or to various unitless ratios that communicate the retained fraction of each nuclide. The simplest ratio was the measured activity of a particle, $A_{i}$, normalized to the average measured activity for all particles in a sample of $n$ particles, reported herein as the measured vs. average (M/A) value. For example,

$$
\frac{\mathrm{A}_{\mathrm{i}}\left({ }^{144} \mathrm{Ce}\right)}{\sum_{\mathrm{i}=1}^{\mathrm{n}}\left(\frac{1}{\mathrm{n}}\right) \mathrm{A}_{\mathrm{i}}\left({ }^{144} \mathrm{Ce}\right)}
$$

is the ${ }^{144} \mathrm{Ce} \mathrm{M} / \mathrm{A}$ value for Particle $i$ (i.e., the measured ${ }^{144} \mathrm{Ce}$ activity of Particle $i$, normalized to the average ${ }^{144} \mathrm{Ce}$ activity). The ratio form in Eq. $(0.1)$ was used to generate ${ }^{137} \mathrm{Cs},{ }^{144} \mathrm{Ce}$, and ${ }^{106} \mathrm{Ru}$ histograms of the IMGA survey results, which were centered on unity and had a distribution that resulted from measurement uncertainty and real particle-to-particle variation in isotopic content. For particles with negligible radionuclide release, this real particle-to-particle variation was related to variation in fissionable material and burnup, which might occur because of variation in kernel size and local neutron fluence.

A calculated value for the expected activity of a given radionuclide in each particle was estimated from the average calculated activity for that nuclide, $A_{\text {calc }}$, predicted by physics simulations (Sterbentz 2015), and multiplied by the normalized activity of a different and preferably well-retained radionuclide to adjust for particle-to-particle variation in fissionable material and burnup. For instance,

$$
\mathrm{A}_{\text {calc }}\left({ }^{137} \mathrm{Cs}\right) \frac{\mathrm{A}_{\mathrm{i}}\left({ }^{144} \mathrm{Ce}\right)}{\sum_{\mathrm{i}=1}^{\mathrm{n}}\left(\frac{1}{\mathrm{n}}\right) \mathrm{A}_{\mathrm{i}}\left({ }^{144} \mathrm{Ce}\right)}
$$

is the calculated ${ }^{137} \mathrm{Cs}$ activity of Particle $i$ after adjusting for particle-to-particle variation in fissionable material and burnup using the normalized ${ }^{144} \mathrm{Ce}$ activity of Particle $i$. The normalized ${ }^{144} \mathrm{Ce}$ activity was typically used for making the adjustment to the average calculated ${ }^{137} \mathrm{Cs}$ activity to account for the variation in fissionable material and burnup in each particle. However, the normalized ${ }^{106} \mathrm{Ru}$ activity was used if it could be measured with greater accuracy, which was the case for later PIE because of the shorter ${ }^{144} \mathrm{Ce}$ half-life and lower energy of the ${ }^{144} \mathrm{Ce}$ gamma emission. 
The ratio of the measured activity in Particle $i$ vs. the calculated activity of Particle $i$ is reported herein as the measured vs. calculated $(\mathrm{M} / \mathrm{C})$ value. For example,

$$
\frac{\mathrm{A}_{\mathrm{i}}\left({ }^{137} \mathrm{Cs}\right)}{\mathrm{A}_{\text {calc }}\left({ }^{137} \mathrm{Cs}\right) \frac{\mathrm{A}_{\mathrm{i}}\left({ }^{144} \mathrm{Ce}\right)}{\sum_{\mathrm{i}=1}^{\mathrm{n}}\left(\frac{1}{n}\right) \mathrm{A}_{\mathrm{i}}\left({ }^{144} \mathrm{Ce}\right)}}
$$

is the ${ }^{137} \mathrm{Cs} \mathrm{M} / \mathrm{C}$ value for Particle $i$, adjusted for particle-to-particle variation in fissionable material and burnup using the normalized ${ }^{144} \mathrm{Ce}$ activity of Particle $i$. The ratio form in Eq. (0.3) was used to generate a ${ }^{137} \mathrm{Cs} \mathrm{M} / \mathrm{C}$ histogram from the IMGA survey data that illustrated the cesium retention in each particle, in which particles with low cesium retention could be identified as discrete values below the main distribution. These low cesium particles were sorted out during the IMGA survey and labeled as special particles (SPs) using the compact number, segment number, and a sequential ID (e.g., Particle 104-S1-SP01, Particle 104-S1-SP02). The SPs were retained for possible future examination.

After IMGA survey, SPs and a randomly riffled subsample of about $45 \mathrm{RS}$ particles were subjected to longer gamma counting to obtain better counting statistics. The $\mathrm{M} / \mathrm{C}$ values were calculated from the long-count IMGA data for radionuclides other than ${ }^{137} \mathrm{Cs}$ using the ratio form in Eq. (0.3), but rather than ${ }^{144} \mathrm{Ce}$, the normalized ${ }^{137} \mathrm{Cs}$ activity was used to make the adjustment to the average calculated radionuclide activities. For example,

$$
\frac{\mathrm{A}_{\mathrm{i}}\left({ }^{154} \mathrm{Eu}\right)}{\mathrm{A}_{\text {calc }}\left({ }^{154} \mathrm{Eu}\right) \frac{\mathrm{A}_{\mathrm{i}}\left({ }^{137} \mathrm{Cs}\right)}{\sum_{\mathrm{i}=1}^{\mathrm{n}}\left(\frac{1}{n}\right) \mathrm{A}_{\mathrm{i}}\left({ }^{137} \mathrm{Cs}\right)}}
$$

is the ${ }^{154} \mathrm{Eu} \mathrm{M} / \mathrm{C}$ value for Particle $i$, adjusted for particle-to-particle variation in fissionable material and burnup using the normalized ${ }^{137} \mathrm{Cs}$ activity of Particle $i$. The ${ }^{137} \mathrm{Cs}$ radionuclide was chosen for the adjustment over ${ }^{144} \mathrm{Ce}$ based on comparisons showing that ${ }^{137} \mathrm{Cs}$ was a better choice for the inventory adjustment (Hunn et al. 2012). In the absence of $\mathrm{SiC}$ failure, cesium was retained well by the $\mathrm{SiC}$ coating, sometimes better than cerium. Furthermore, the buildup of ${ }^{137} \mathrm{Cs}$ was much more linear than ${ }^{144} \mathrm{Ce}$ as a function of burnup throughout the course of the AGR program irradiations because the irradiation tests extended over several ${ }^{144} \mathrm{Ce}$ half-lives. The average $\mathrm{M} / \mathrm{C}$ for well-retained radionuclides was not always close to unity, because error in the calculated inventory sometimes resulted in an offset which could be significant. The offset was substantial for the radionuclides of europium and antimony as a result of large errors in the calculated values.

Another calculated ratio, reported herein as the measured vs. adjusted average (M/AA) value, was determined in a manner similar to that used to determine $\mathrm{M} / \mathrm{C}$, except the offset in the calculated activity was mostly removed by replacing the average calculated activity, $A_{\text {calc }}$, predicted by physics simulations and used in Eqs. (0.3) and (0.4) with the average measured activity. For instance,

$$
\frac{\mathrm{A}_{\mathrm{i}}\left({ }^{154} \mathrm{Eu}\right)}{\sum_{\mathrm{i}=1}^{\mathrm{n}}\left(\frac{1}{\mathrm{n}}\right) \mathrm{A}_{\mathrm{i}}\left({ }^{154} \mathrm{Eu}\right) \frac{\mathrm{A}_{\mathrm{i}}(137 \mathrm{CS})}{\sum_{\mathrm{i}=1}^{\mathrm{n}}\left(\frac{1}{\mathrm{n}}\right) \mathrm{A}_{\mathrm{i}}\left({ }^{137} \mathrm{CS}\right)}}
$$

is the ${ }^{154} \mathrm{Eu} \mathrm{M} / \mathrm{AA}$ value for Particle $i$, adjusted for particle-to-particle variation in fissionable material and burnup using the normalized ${ }^{137} \mathrm{Cs}$ activity of Particle $i$. This ratio form is useful for identifying particles with average retention. 


\section{AGR-3/4 COMPACT 8-4}

\subsection{RADIAL DECONSOLIDATION AND DIMENSIONAL ANALYSIS OF COMPACT 8-4}

Three annular rings of driver fuel particles and matrix were removed from Compact 8-4 by radially deconsolidating the compact in three stages. The remaining cylindrical core encompassing the DTF particles was then axially deconsolidated. A segment plan to generate four segments of equal volume is shown in Table 4-1. Radial deconsolidation was paused several times during each deconsolidation stage to obtain a photo, which was manually examined to evaluate progress toward the target diameter for the segment (Table 3-1). At the end of each radial deconsolidation, the compact was raised to the imaging position (Figure 1-2), loose debris on the screen and compact were gently rinsed off into the deconsolidation beaker, the drag paddle was removed, and images of the compact were acquired to measure the residual diameter. At least 50 photos of the rotating compact were obtained after each segment based on previous results which found this number was sufficient to ensure a well-distributed sampling of compact rotations (Hunn et al. 2020). Table 4-2 shows the actual segment dimensions and volumes as determined by automated image analysis of the photos (discussed below); the time that deconsolidation was active (power applied) for each radially deconsolidated segment is also shown.

Table 3-1. Equal volume segment plan for Compact 8-4

\begin{tabular}{lcccc}
\hline Quantity & Segment 1 & Segment 2 & Segment 3 & Segment 4 \\
\hline Initial diameter $(\mathrm{mm})$ & 12.126 & 10.501 & 8.574 & 6.063 \\
Target diameter $(\mathrm{mm})$ & 10.501 & 8.574 & 6.063 & 0 \\
Segment thickness $(\mathrm{mm})$ & 0.812 & 0.964 & 1.256 & solid \\
Segment volume $\left(\mathrm{cm}^{3}\right)$ & 0.361 & 0.361 & 0.361 & 0.361 \\
\hline
\end{tabular}

Note: Average diameter of the irradiated compact was $12.126 \mathrm{~mm}$ with a standard deviation of $0.017 \mathrm{~mm}$, and length from a single measurement was $12.510 \mathrm{~mm}$ (Stempien et al. 2016).

Table 3-2. Segment results for Compact 8-4 measured with automated photo analysis

\begin{tabular}{lcccc}
\hline Quantity & Segment 1 & Segment 2 & Segment 3 & Segment 4 \\
\hline Initial diameter (mm) & 12.126 & 10.858 & 9.186 & 6.798 \\
Residual diameter (mm) & 10.858 & 9.186 & 6.798 & 0 \\
Segment thickness (mm) & 0.634 & 0.836 & 1.194 & solid \\
Segment volume (cm $\left.{ }^{3}\right)$ & 0.286 & 0.329 & 0.375 & 0.454 \\
Deconsolidation time (min) & 28 & 23 & 25 & \\
\hline
\end{tabular}

As shown in the compact images from each stage of deconsolidation in Figure 3-1, the removal of material was generally uniform, resulting in an approximately cylindrical remainder after each segment. This was as expected based on prior development of the radial deconsolidation process, which found that applying the required electrolytic current to the compact through a Pt-Rh screen resulted in a gentle shear force, mechanically removing particles and matrix debris loosened by intercalation of the graphite matrix by nitrate anions (Helmreich, Montgomery, and Hunn 2015). The nylon threaded rod shown in Figure 3-1 was inserted into the hollow axle tube as part of the mounting process. To bond the compact to the rod, conducting epoxy was packed into half the axle, and the nylon threaded rod was inserted until it was in contact with the epoxy. A nylon nut on the rod prevented it from pressing on the epoxy. The axle was loaded into the hot cell, and the sample holder (axle, gear, and bracket) was assembled (Figure 1-3). The compact and axle were loaded into a mounting jig developed at INL to align the axle to the center of the compact (Stempien 2017). The axle was placed in contact with the compact to provide electrical connection during axial deconsolidation (Figure 1-4), and then the nylon nut was backed off about one 
turn and pressed into the axle. This ejected an easily metered small volume of epoxy, which squeezed through slots in the end of the axle and formed a small, tapered bead at the joining (Figure 3-1).

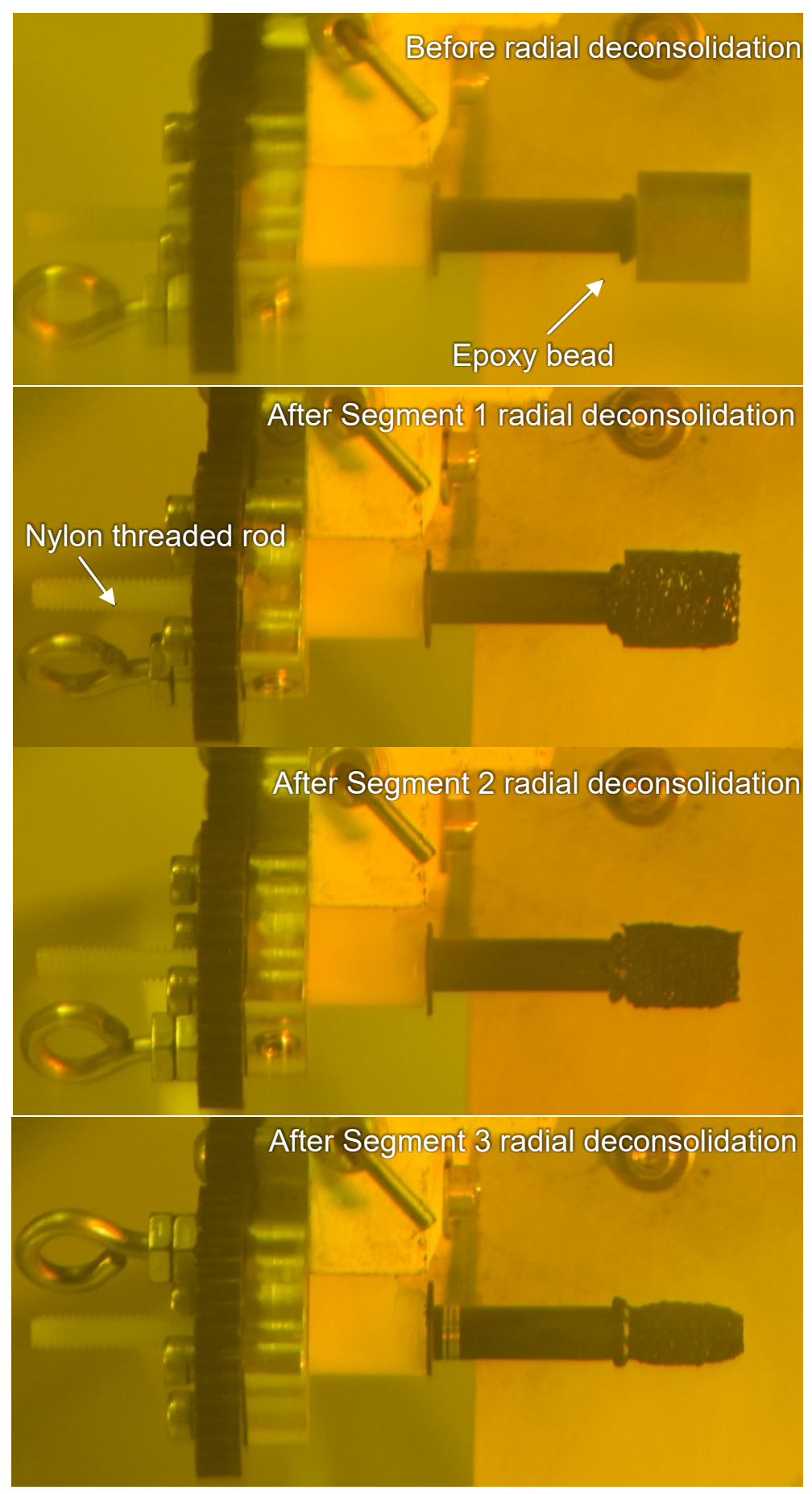

Figure 3-1. Compact 8-4 at each stage of radial deconsolidation.

The residual diameter of the compact after the radial deconsolidation of Segment 3 was close to the outer diameter of the stainless-steel tube that was used as a drive axle for compact rotation. The axle diameter of $6 \mathrm{~mm}$ presented a practical limit to the outer diameter of the solid core segment. This diameter was 
more than sufficient to ensure that any residuals of the DTF particles that remained in their original location $(<1.5 \mathrm{~mm}$ from the compact axis) were located within the core (Figure 1-1).

Analysis of compact images was performed using a custom MATLAB script which automatically segmented the compact and the mounting axle from the "green screen" background. This approach worked very well in laboratory testing (Helmreich, Montgomery, and Hunn 2015), but faced some challenges in the hot cell environment due to insufficient lighting and the yellow tint of the hot cell windows. Modifications to the code and the introduction of secondary lighting helped to resolve these issues. While the compact segmentation was used for determination of the average compact diameter, the axle segmentation was used to apply a rotational correction to account for wobble or precession; however, careful camera alignment and shimming of the deconsolidation apparatus to remove wobble resulted in only minor deviation of the axle and compact angle relative to the horizontal image axis.

Images were calibrated using a white block in the same plane as the compact with two lines separated by a known distance, as shown in Figure 3-2. The inner corners where the horizontal and vertical lines met on the calibration block were found in each image using an automated algorithm. These corners were used to calculate the pixel size of the image. This method had a significant advantage over calibration using the known diameter of the mounting axle, because the width of the calibration block was much greater than the diameter of the mounting axle, thus reducing the impact of edge selection on the final calibration value.

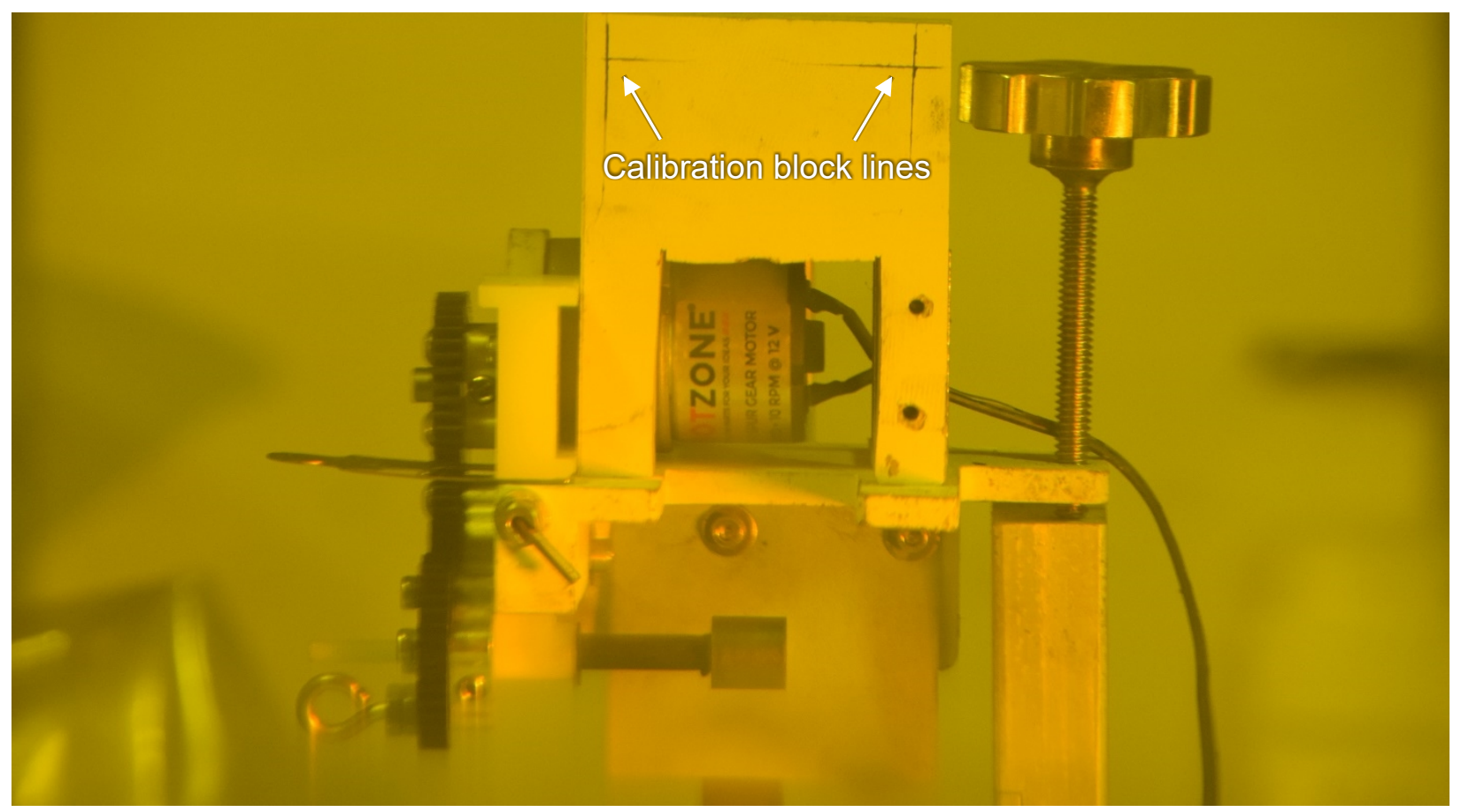

Figure 3-2. Compact 8-4 before radial deconsolidation with calibration block.

As shown in Table 3-3, the image calibration values from the calibration block were highly consistent within each segment image set, as reflected by low standard deviations. Greater variation was observed between image sets, likely caused by minor changes in camera positioning. Comparison of the average compact diameter before deconsolidation as measured by image analysis to the known irradiated compact diameter showed a difference of $1.02 \%$. This difference may have been caused by a minor difference between the distance from the camera to the compact and the distance from the camera to the calibration block or a persistent bias in identification of the calibration line edges. As such, it was assumed that this 
difference would be consistent in each image set, so an adjustment of $1.02 \%$ was applied to the measured calibration value for each segment.

Table 3-3. Raw and adjusted calibration values in pixels/mm used for Compact 8-4 image analysis

\begin{tabular}{lcc}
\hline Segment & $\begin{array}{c}\text { Raw calibration } \\
\text { (pix/mm) }\end{array}$ & $\begin{array}{c}\text { Adjusted calibration } \\
\text { (pix/mm) }\end{array}$ \\
\hline Segment 0 & $25.413 \pm 0.004$ & $25.157 \pm 0.004$ \\
Segment 1 & $25.309 \pm 0.006$ & $25.054 \pm 0.006$ \\
Segment 2 & $24.280 \pm 0.005$ & $24.036 \pm 0.005$ \\
Segment 3 & $25.372 \pm 0.009$ & $25.116 \pm 0.009$ \\
\hline
\end{tabular}

Examples of the automated image segmentation of the compact (blue) and the axle (red) for photos from each stage of radial deconsolidation are given in Figure 3-3. The left edge of the compact is truncated based on a user-defined search area to avoid accidental inclusion of the epoxy. Image analysis results were manually inspected to confirm accuracy.

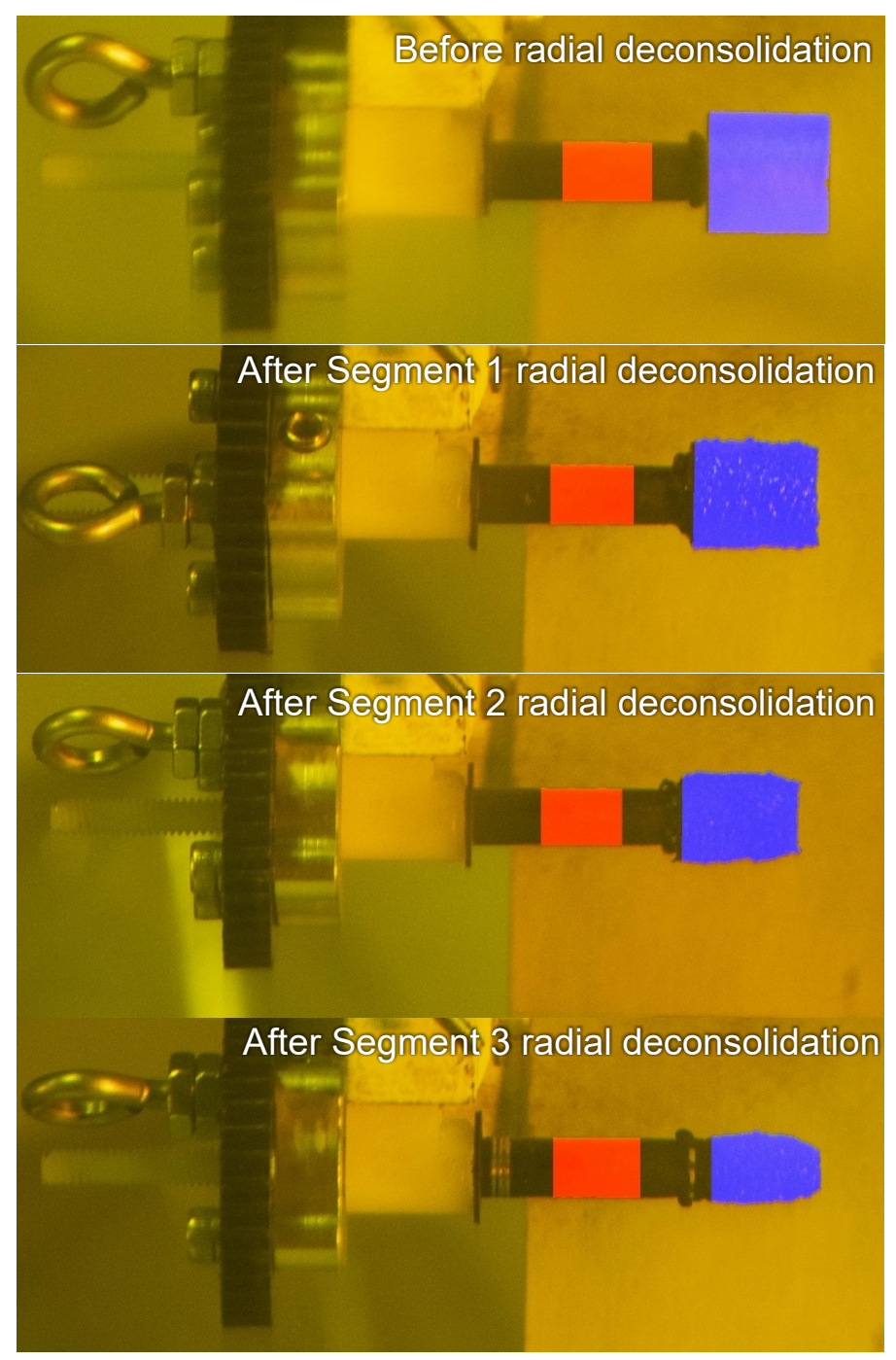

Figure 3-3. Examples of Compact 8-4 automated photo analysis at each stage of radial deconsolidation. 


\subsection{RDLBL OF COMPACT 8-4}

Once the target diameter for each segment of Compact 8-4 was reached, radial deconsolidation was stopped for collection of particles, matrix debris, and acid into labeled storage vials. To ensure complete transfer, the beaker was rinsed several times and the rinse was collected in the same storage vial as the other material from that segment. The deconsolidated material and acid from each segment were analyzed using a slightly modified version of the process shown in Figure 2-1. The $6 \mathrm{~mol} / \mathrm{L}$ nitric acid used for deconsolidation was filtered through the porous disk in the Soxhlet thimble for separate analysis, and concentrated $(15.8 \mathrm{~mol} / \mathrm{L})$ nitric acid was used for the extractions and pot leaches. After the first two preburn Soxhlet extractions, the particles and matrix were not digested and sieved as shown in Figure 2-1. Instead, the particles and matrix were left in the Soxhlet thimble and were rinsed with water to remove any nitric acid. They were then burned at $750^{\circ} \mathrm{C}$ for about 72 hours. The particles and matrix ash were then leached twice. The details of the equipment and methods for LBL using a Soxhlet extractor have been previously reported (Hunn et al. 2013; Hunn and Montgomery 2020). The RDLBL data for select isotopes of actinides and fission products from each LBL step are provided in APPENDIX A and a summary is given in Table 3-4. Discussion of these results is provided in Section 5.

Table 3-4. Comparison of particle-equivalents of select nuclides in Compact 8-4 segments

\begin{tabular}{lccccc}
\hline Nuclide & Segment 1 & Segment 2 & Segment 3 & Segment 4 & \multicolumn{1}{c}{ Total } \\
\hline${ }^{235} \mathrm{U}$ & $(0.416)$ & $(1.048)$ & $(0.955)$ & $(14.938)$ & $(17.357)$ \\
${ }^{239} \mathrm{Pu}$ & $(0.401)$ & $(0.603)$ & $(0.671)$ & $(14.618)$ & $(16.293)$ \\
${ }^{144} \mathrm{Ce}$ & $(0.184)$ & $(0.217)$ & $(0.344)$ & $(17.724)$ & $(18.469)$ \\
${ }^{137} \mathrm{Cs}$ & $(0.090)$ & $(0.190)$ & $(0.132)$ & $(2.162)$ & $(2.574)$ \\
${ }^{90} \mathrm{Sr}$ & $(5.030)$ & $(5.974)$ & $(8.948)$ & $(12.384)$ & $(32.336)$ \\
${ }^{154} \mathrm{Eu}{ }^{a}$ & $(6.274)$ & $(6.738)$ & $(10.617)$ & $(15.290)$ & $(38.919)$ \\
\hline
\end{tabular}

${ }^{a}$ Values for ${ }^{154} \mathrm{Eu}$ were adjusted for offset in calculated inventory by dividing by the average measured $\mathrm{M} / \mathrm{C}$ ratio (0.89) for particles from Compacts 1-4, 10-4, and 7-4 which were gamma counted using IMGA.

Table 3-5 shows the particle-equivalents of ${ }^{144} \mathrm{Ce}$ detected in each RDLBL solution. The total ${ }^{144} \mathrm{Ce}$ detected was 18.5 particle-equivalents, which was consistent with the presence of 20 DTF particles. The data are insufficient to conclude whether the "missing" 1.5 particle-equivalents of ${ }^{144} \mathrm{Ce}$ were caused by measurement uncertainty (exacerbated by the large number of measurements), diffusion out of the compact, smaller-than-average DTF kernels, offset in calculated inventory, or some combination thereof. For comparison, the total ${ }^{235} \mathrm{U}$ detected was 17.4 particle-equivalents, which is similarly close to the nominal 20 DTF particles, but slightly low. The similarity in the apparent error for these two isotopes may indicate a shared cause outside of measurement uncertainty, but there is not enough evidence to determine that conclusively.

Table 3-5. Particle-equivalents of ${ }^{144} \mathrm{Ce}$ detected in Compact 8-4 RDLBL solutions

\begin{tabular}{lccccc}
\hline RDLBL Step & Segment 1 & Segment 2 & Segment 3 & Segment 4 & Total \\
\hline Deconsolidation acid & $(0.046)$ & $(0.109)$ & $(0.070)$ & $(6.097)$ & $(6.322)$ \\
Preburn leach 1 & $<(0.0047)$ & $(0.012)$ & $(0.020)$ & $(2.249)$ & $(2.282)$ \\
Preburn leach 2 & $<(0.010)$ & $<(0.008)$ & $<(0.015)$ & $(0.333)$ & $(0.333)$ \\
Postburn leach 1 & $(0.137)$ & $(0.096)$ & $(0.244)$ & $(9.003)$ & $(9.481)$ \\
Postburn leach 2 & $<(0.0084)$ & $<(0.0054)$ & $(0.0093)$ & $(0.042)$ & $(0.051)$ \\
\hline Total & $(0.184)$ & $(0.217)$ & $(0.344)$ & $(17.724)$ & $(18.469)$ \\
\hline
\end{tabular}

The total amount of ${ }^{144} \mathrm{Ce}$ detected in each concentric cylindrical segment progressively decreased with 
each segment from the DTF-containing core outwards. This progression is shown graphically in Figure 3-4 in terms of the number of DTF particle-equivalents detected in each segment.

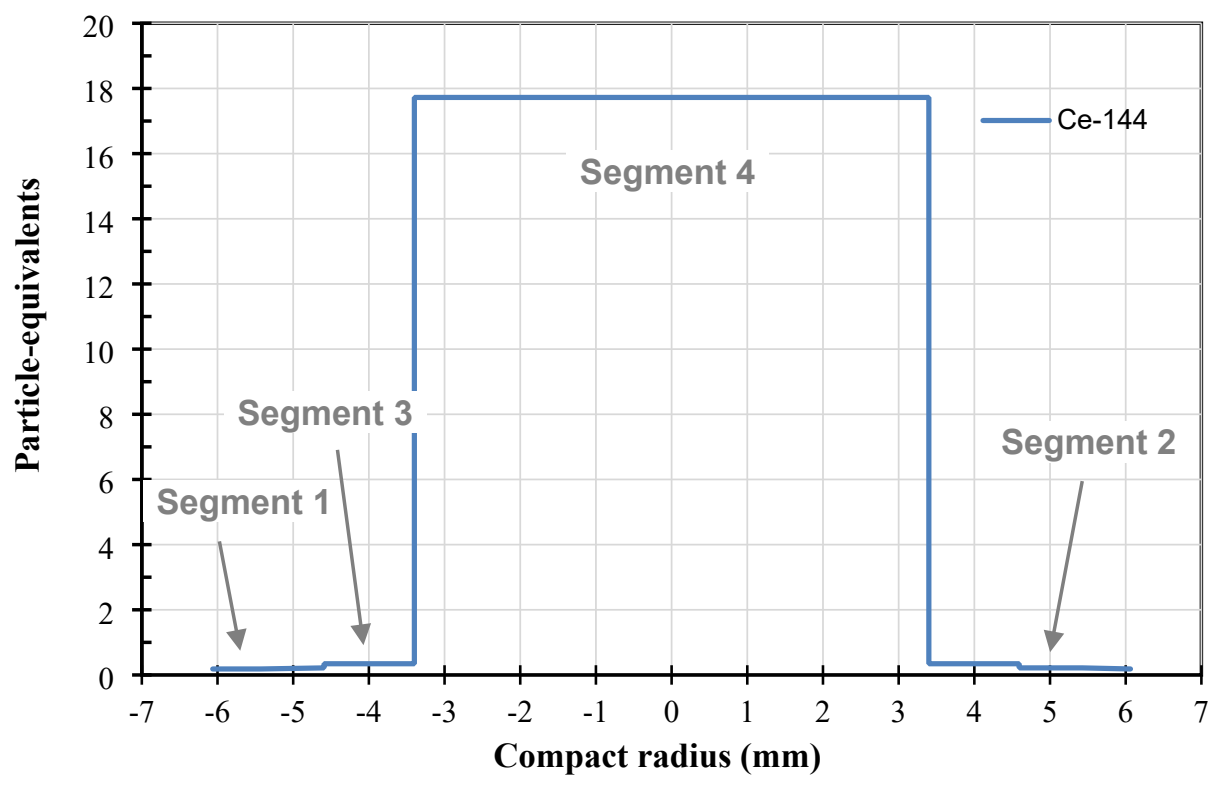

Figure 3-4. Distribution of ${ }^{144} \mathrm{Ce}$ from DTF particles in Compact 8-4. 


\section{AGR-3/4 COMPACT 7-4}

\subsection{RADIAL DECONSOLIDATION AND DIMENSIONAL ANALYSIS OF COMPACT 7-4}

Three annular rings of driver fuel particles and matrix were removed from Compact 7-4 by radially deconsolidating the compact in three stages. The remaining cylindrical core encompassing the DTF particles was then axially deconsolidated. The original plan was to generate four segments of equal volume, as shown in Table 4-1. However, near the beginning of the third deconsolidation, the compact broke away from the axle and fell into the collection beaker, rendering further radial deconsolidation impossible. At that point, image analysis showed that only about $9.2 \%$ of the total compact volume had been deconsolidated into the third segment. It was decided that this volume was too small to be analyzed on its own and the uncertainties in the volumes of what had been radially deconsolidated and what remained were too high, so the particles, matrix debris, and acid from the third radial deconsolidation were combined with those from the final deconsolidation of the remaining solid compact. This final deconsolidation step required the use of a special deconsolidation rig to hold the residual compact partially submerged in nitric acid while completing the electrolytic circuit. A sketch of this apparatus is included in APPENDIX D. As described for Compact 8-4 in Section 3.1, the radial deconsolidation process was paused several times during each stage to obtain photos for manual examination and evaluation of progress toward the segment target diameter. Once the target diameter was reached, a set of 50 photos was acquired at random rotations of the residual compact for dimensional measurement. Table 4-2 shows the segment dimensions and volumes as determined by analysis of these images as well as the time that deconsolidation was active (power applied) for each segment.

Table 4-1. Equal volume segment plan for Compact 7-4

\begin{tabular}{lcccc}
\hline Quantity & Segment 1 & Segment 2 & Segment 3 & Segment 4 \\
\hline Initial diameter $(\mathrm{mm})$ & 12.09 & 10.47 & 8.55 & 6.05 \\
Target diameter $(\mathrm{mm})$ & 10.47 & 8.55 & 6.05 & 0 \\
Segment thickness $(\mathrm{mm})$ & 0.81 & 0.94 & 1.25 & Solid \\
Segment volume $\left(\mathrm{cm}^{3}\right)$ & 0.36 & 0.36 & 0.36 & 0.36 \\
\hline Note: Average diameter of the irradiated compact was $12.094 \mathrm{~mm}$, with a standard deviation of \\
0.009 mm; length from a single measurement was $12.5095 \mathrm{~mm}$ (Stempien et al. 2016).
\end{tabular}

Table 4-2. Segment results for Compact 7-4 measured with automated photo analysis

\begin{tabular}{lccc}
\hline Quantity & Segment 1 & Segment 2 & Segment 3 \\
\hline Initial diameter $(\mathrm{mm})$ & 12.09 & 10.61 & 9.10 \\
Residual diameter $(\mathrm{mm})$ & 10.61 & 9.10 & 0 \\
Segment thickness $(\mathrm{mm})$ & 0.74 & 0.76 & Solid \\
Segment volume $\left(\mathrm{cm}^{3}\right)$ & 0.33 & 0.29 & 0.81 \\
Deconsolidation time $(\mathrm{min})$ & 44 & 20 & 54 \\
\hline
\end{tabular}

As shown in the compact images from each stage of deconsolidation in Figure 4-1, the removal of material was generally uniform, resulting in an approximately cylindrical remainder after each segment. The final image in Figure 4-1 shows the residual compact after it was detached from the axle during the third radial deconsolidation segment. Because the usual method of rotating the compact while acquiring at least 50 photographs at random rotational angles was not possible for the remainder, two orthogonal images were acquired to estimate the remaining compact diameter. Based on this estimate, it was determined that an insufficient volume of material had been removed in the aborted third deconsolidation, resulting in combining the gathered material from the third segment and the deconsolidated residual 
compact which was deconsolidated using a special rig. The inability to precisely measure the residual compact volume after the aborted third radial deconsolidation was not an issue, as the small amount of material removed in the third radial deconsolidation segment was combined with the residual core.

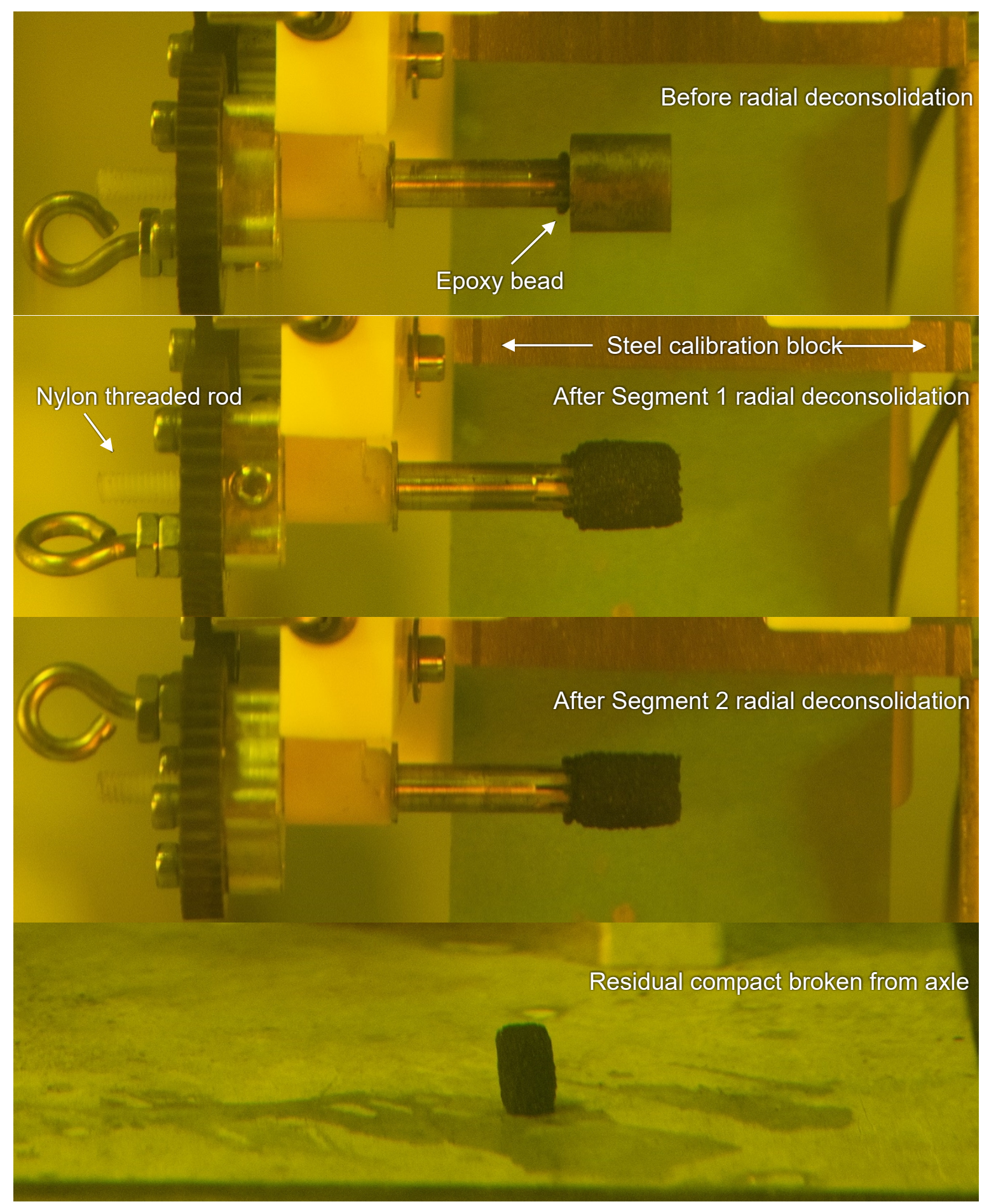

Figure 4-1. Compact 7-4 at each stage of radial deconsolidation. 
Automated image analysis was accomplished using a custom MATLAB script as described in Section 3.1. Instead of calibrating each image for Compact 7-4 using the axle diameter, a larger calibration block was included in each image. As shown in Figure 4-1, a new steel calibration block was made to replace the one used for Compact 8-4. This new calibration block was designed to sit closer to the compact. This was accomplished by sliding the block into the mounting bracket for the paddle (which was removed for measurement photographs). This positioning improved the quality and consistency of the calibration by reducing the effects of camera angle on the relative magnification of the compact and the calibration block and by ensuring that the face of the block was in the imaging plane of the compact as long as it was snugly pressed into the bracket. Both the inner and the outer widths between the lines on the calibration block were known, so both were measured in the images, and the average of the two widths was used for calibration.

Table 4-3 shows the average and standard deviation of the calibration factors used for the analysis. As with Compact 8-4, the known diameter of the compact as measured with a micrometer (Stempien et al. 2016) was used as a correction factor and applied to the calibration values of each image set. For Compact $7-4$, the initial diameter as measured by image analysis was $2.82 \%$ lower than the known compact diameter, so calibration values for each image set were adjusted downward by that percentage. Compared to Compact 8-4, the standard deviations of the calibration factors for each segment were slightly larger, but the variation in the calibration factors between segments was much lower. The increase in standard deviation was attributed to the greater difficulty in consistently segmenting the measurement marks on the steel calibration block, and the increased consistency between image sets was attributed to the improved positioning of the block.

Table 4-3. Raw and adjusted calibration values in pixels/mm used for Compact 7-4 image analysis

\begin{tabular}{lcc}
\hline Segment & $\begin{array}{c}\text { Raw calibration } \\
\text { (pix/mm) }\end{array}$ & $\begin{array}{c}\text { Adjusted calibration } \\
\text { (pix/mm) }\end{array}$ \\
\hline Segment 0 & $26.164 \pm 0.027$ & $25.446 \pm 0.027$ \\
Segment 1 & $26.226 \pm 0.012$ & $25.507 \pm 0.012$ \\
Segment 2 & $26.237 \pm 0.016$ & $25.617 \pm 0.016$
\end{tabular}

Examples of the automated image segmentation of the compact (blue) and the axle (red) for photos from each stage of radial deconsolidation are given in Figure 4-2. The left edge of the compact is truncated based on a user-defined search area to avoid accidental inclusion of the epoxy. Analysis results were manually inspected to confirm accuracy. The poor lighting in the hot cells caused automated segmentation of the axle from the background to fail regularly, as shown by the red overlay in Figure 4-2. This was not an issue, as the calibration block was used for image calibration, and the compact was very close to horizontal in each image, so image rotation based on axle angle was not necessary. 


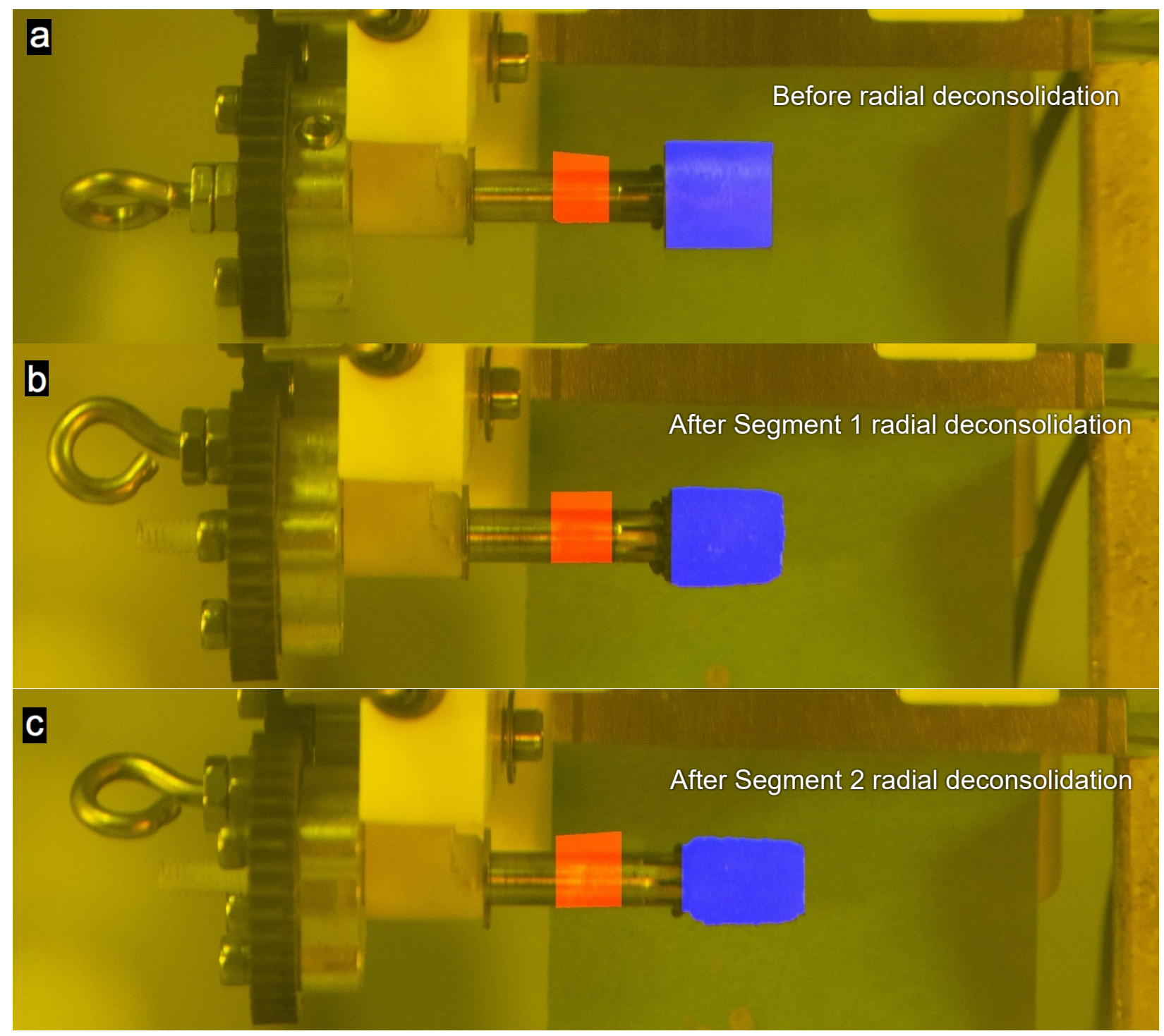

Figure 4-2. Examples of Compact 7-4 automated photo analysis at each stage of radial deconsolidation.

\subsection{RDLBL OF COMPACT 7-4}

After completion of the radial deconsolidation of each Compact 7-4 segment, the particles and matrix debris were subjected to the RDLBL process shown in Figure 2-1. The RDLBL data for select actinides and fission products (both radionuclides and stable nuclides) are provided for each primary leach solution in APPENDIX A and a summary is given in Table 4-4. Discussion of these results in provided in Section 5 . 
Table 4-4. Comparison of particle-equivalents of select nuclides in Compact 7-4 segments

\begin{tabular}{lcccc}
\hline Nuclide & Segment 1 & Segment 2 & Segment 3 & Total \\
\hline${ }^{235} \mathrm{U}$ & $(1.220)$ & $(0.232)$ & $(14.666)$ & $(16.118)$ \\
${ }^{239} \mathrm{Pu}$ & $(1.980)$ & $(0.494)$ & $(14.257)$ & $(16.731)$ \\
${ }^{144} \mathrm{Ce}$ & $(1.298)$ & $(0.277)$ & $(17.089)$ & $(18.664)$ \\
${ }^{137} \mathrm{Cs}$ & $(1.046)$ & $(0.249)$ & $(4.741)$ & $(6.036)$ \\
${ }^{90} \mathrm{Sr}$ & $(10.190)$ & $(8.909)$ & $(22.138)$ & $(41.237)$ \\
${ }^{154} \mathrm{Eu}^{a}$ & $(13.710)$ & $(11.960)$ & $(26.458)$ & $(52.128)$ \\
\hline${ }^{a}$ Values for ${ }^{154} \mathrm{Eu}$ were adjusted for offset in calculated inventory by dividing by the measured \\
average M/C ratio $(0.92)$ from the 45 particles that were gamma counted with IMGA
\end{tabular}

Table 4-5 shows the particle-equivalents of ${ }^{144} \mathrm{Ce}$ detected in each RDLBL solution. The total ${ }^{144} \mathrm{Ce}$ detected in the RDLBL was 18.7 particle-equivalents. This was somewhat lower than expected based on 20 DTF particles, particularly given that one particle-equivalent appears to have come from a driver fuel particle broken during radial deconsolidation as discussed below. As with Compact 8-4, the total ${ }^{235} \mathrm{U}$ detected was again slightly lower than expected for the nominal 20 particle-equivalents from DTF particles, even more so after accounting for the particle-equivalent from the broken driver fuel particle. As described in Section 3.2, this may be due to measurement uncertainty (exacerbated by the large number of measurements), diffusion out of the compact, smaller-than-average DTF kernels, offset in the calculated inventory, or some combination thereof.

Table 4-5. Particle-equivalents of ${ }^{144}$ Ce detected in Compact 7-4 RDLBL solutions

\begin{tabular}{lcccr}
\hline RDLBL Step & Segment 1 & Segment 2 & Segment 3 & Total \\
\hline Deconsolidation acid & $(1.025)$ & $(0.083)$ & $(4.397)$ & $(5.505)$ \\
Preburn leach 1 & $<(0.056)$ & $<(0.018)$ & $(2.304)$ & $(2.304)$ \\
Preburn leach 2 & $<(0.014)$ & $<(0.0097)$ & $(0.360)$ & $(0.360)$ \\
Postburn matrix leach 1 & $<(0.035)$ & $(0.046)$ & $(3.801)$ & $(3.847)$ \\
Postburn matrix leach 2 & $<(0.012)$ & $<(0.0078)$ & $(0.036)$ & $(0.036)$ \\
Postburn particle leach 1 & $(0.258)$ & $(0.142)$ & $(5.951)$ & $(6.352)$ \\
Postburn particle leach 2 & $(0.014)$ & $(0.0065)$ & $(0.239)$ & $(0.260)$ \\
\hline Preburn subtotal & $(1.025)$ & $(0.128)$ & $(10.899)$ & $(12.052)$ \\
Postburn particle subtotal & $(0.273)$ & $(0.149)$ & $(6.190)$ & $(6.612)$ \\
Total & $(1.298)$ & $(0.277)$ & $(17.089)$ & $(18.664)$ \\
\hline
\end{tabular}

As shown in Figure 4-3, the quantity of ${ }^{144}$ Ce detected in each segment did not follow the expected trend of progressive decrease moving away from the core segment due to an increase in concentration in the outermost segment. This increase is matched in the uranium and plutonium isotopes detected for Segment 1, all of which are near one particle-equivalent. This indicates that these isotopes came from a broken driver fuel particle rather than diffusion from a DTF particle in the core. Approximately half a particle-equivalent inventory of ${ }^{137} \mathrm{Cs}$ and ${ }^{134} \mathrm{Cs}$ were present in Segment 1, which was significantly higher than the inventory of those isotopes in Segment 2. These levels for Cs isotopes indicate that the failed driver fuel particle likely broke during radial deconsolidation, not during irradiation. 


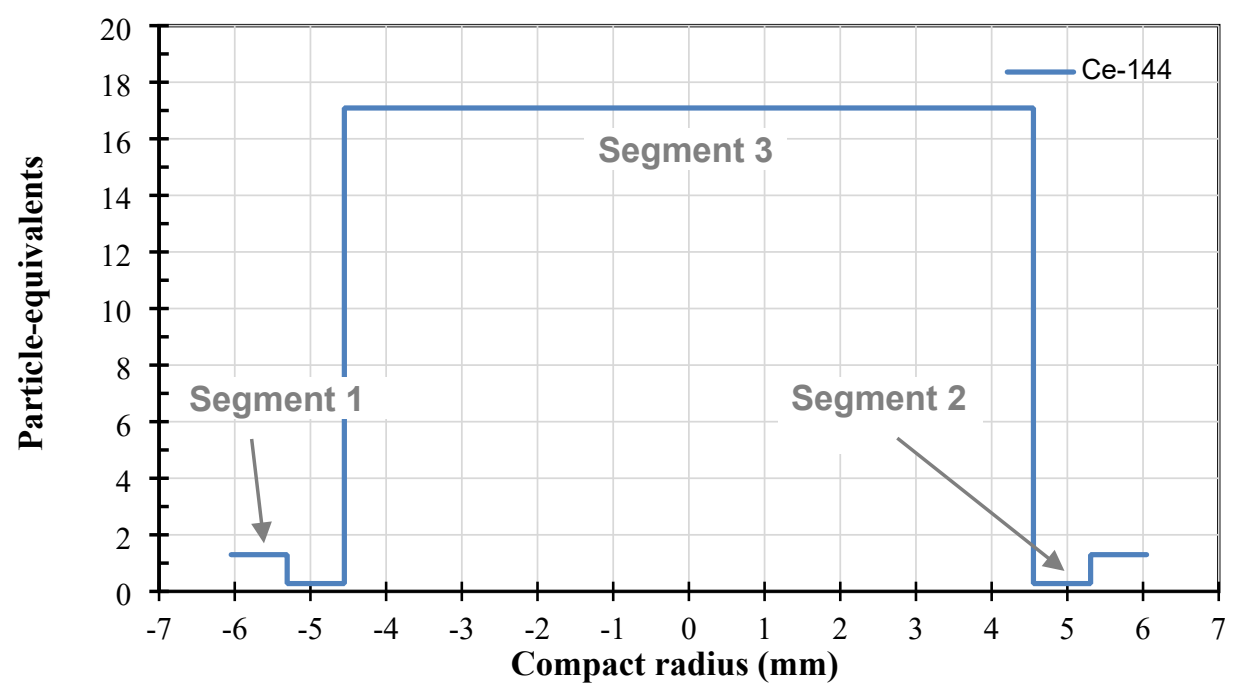

Figure 4-3. Distribution of ${ }^{144}$ Ce from DTF particles in Compact 7-4.

\subsection{IMGA EXAMINATION OF COMPACT 7-4}

Compact 7-4 driver fuel particles were separated from the matrix debris, inspected under a stereoscope, imaged, and counted. Table 4-6 compares the number of particles recovered from each segment with a calculated number based on the segment volume and the total number of particles in the compact. As previously observed in radial deconsolidation of AGR compacts (Hunn et al. 2020), the first segment included a greater number of particles than that which an even distribution based on segment volume would suggest. This was caused by the tight packing of particles near the surface of the compact, as shown in Figure 1-1.

Table 4-6. Number of particles in Compact 7-4 segments

\begin{tabular}{lccc}
\hline Quantity & Segment 1 & Segment 2 & Segment 3 \\
\hline Segment thickness $(\mathrm{mm})$ & 1.48 & 1.51 & Solid \\
Segment volume $\left(\mathrm{cm}^{3}\right)$ measured with automated photo analysis & 0.330 & 0.293 & 0.814 \\
Calculated number of particles assuming an even distribution & 425 & 377 & 1,047 \\
Actual number of particles recovered from each segment & 610 & 353 & $886^{\mathrm{a}}$ \\
\hline
\end{tabular}

${ }^{a}$ The 20 DTF particles were added to the counted number of driver fuel particles recovered from the core segment

Figure 4-4 shows the results of the individual IMGA surveys of particles from each segment combined into a single histogram. Two particles in Segment 3 (Particles 074-S3-SP02 and 074-S3-SP03) were culled out in accordance with the IMGA particle sorting algorithms. Longer counting of Particle 074-S3-SP02 showed that the initial counting irregularity was caused by a smaller-than-average kernel and random variation in the short counting process. Particle 074-S3-SP03 was mounted and imaged using x-ray computed tomography. These images showed that the particle was a cracked shell with approximately one third of the coating layers missing and no kernel remaining. The particle may have been cracked during handling or radial deconsolidation, after which the kernel may have leached out during the initial leaching step before IMGA counting. While this particle was recovered intact, allowing for microstructural examination, it is not unusual for broken particles to separate into small, unrecoverable fragments. This is likely what happened to the Segment 1 driver fuel particle damaged during radial deconsolidation. 


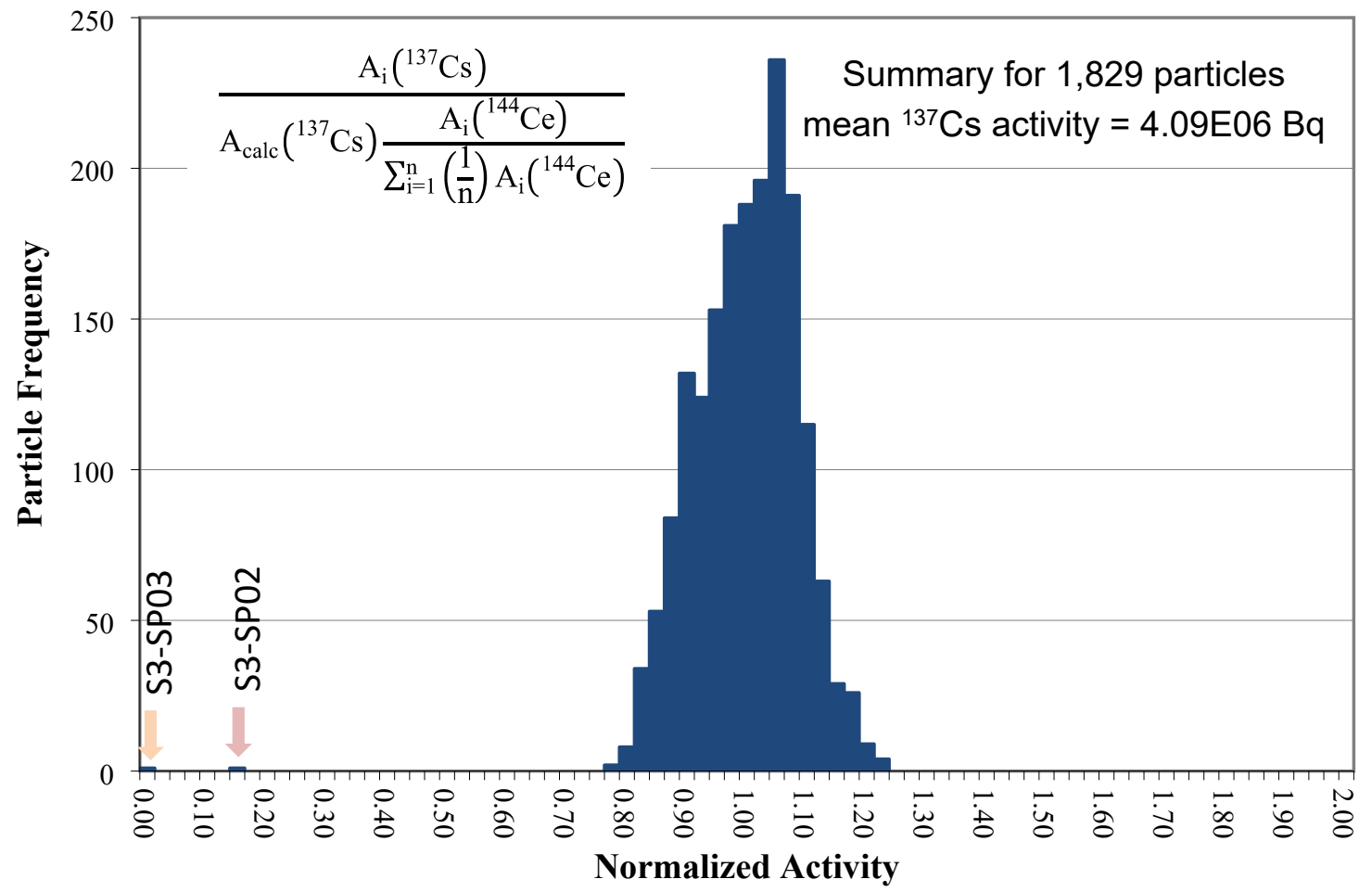

Figure 4-4. Measured vs. calculated ${ }^{137}$ Cs activity in 1,829 particles from AGR-3/4 Compact 7-4.

After the initial IMGA survey, 15 particles were selected randomly from each segment population for extended gamma counting of $4 \mathrm{~h}$ each. Table 4-7 shows the means and standard deviations of the combined sample of 45 RS particles ( 15 from each segment), and full results are provided in APPENDIX B. No outliers were identified within these 45 particles, and mean values were near unity (within the uncertainties in the analysis and calculated inventories) with the exception of ${ }^{125} \mathrm{Sb}$ and ${ }^{154} \mathrm{Eu}$, which had offsets relative to their calculated inventories as has been previously observed in all AGR tests.

Table 4-7. Statistical summary of Compact 7-4 driver fuel particle activities

\begin{tabular}{lccccccc}
\hline & Value & ${ }^{\mathbf{1 0 6}} \mathbf{R u}$ & ${ }^{\mathbf{1 2 5}} \mathbf{S b}$ & ${ }^{\mathbf{1 3 4}} \mathbf{C s}$ & ${ }^{\mathbf{1 3 7}} \mathbf{C s}$ & ${ }^{144} \mathbf{C e}$ & ${ }^{\mathbf{1 5 4}} \mathbf{E u}$ \\
\hline Mean & $\mathrm{Bq}$ & $1.53 \mathrm{E}+07$ & $2.10 \mathrm{E}+05$ & $5.03 \mathrm{E}+06$ & $4.07 \mathrm{E}+06$ & $5.79 \mathrm{E}+07$ & $1.46 \mathrm{E}+05$ \\
Mean & $\mathrm{M} / \mathrm{C}$ & 1.11 & 0.68 & 0.98 & 1.04 & 1.00 & 0.92 \\
$\mathrm{SD}$ & $\mathrm{Bq}$ & $9.2 \%$ & $9.2 \%$ & $8.1 \%$ & $8.0 \%$ & $8.3 \%$ & $8.0 \%$ \\
$\mathrm{SD}$ & $\mathrm{M} / \mathrm{C}$ & $4.2 \%$ & $4.0 \%$ & $1.7 \%$ & - & $3.4 \%$ & $6.0 \%$ \\
\hline
\end{tabular}




\section{DISCUSSION OF RESULTS FOR AGR-3/4 COMPACTS 1-4, 7-4, AND 8-4}

The concentration of select actinides and fission products in particle-equivalents per cubic centimeter were calculated for each segment of AGR-3/4 Compacts 8-4 and 7-4 based on the total quantities detected in Table 3-4 and Table 4-4 and the segment volumes in Table 3-2 and Table 4-2. These results are presented in Figure 5-1 through Figure 5-3 along with concentration profiles calculated in the same manner for AGR-3/4 Compact 1-4 reproduced from (Hunn et al. 2020). Comparison of the results between these compacts alludes to the influence of irradiation temperature on fission product transport as they span a range of irradiation TAVA temperatures of 929,1169 , and $1319^{\circ} \mathrm{C}$ for Compacts $1-4,8-4$, and 7-4 respectively. Note that one particle-equivalent of inventory for each isotope has been subtracted from the outermost segment of Compact 7-4 to account for the driver fuel particle which was broken during radial deconsolidation as discussed in Section 4.2.

A comparison of concentration profiles for ${ }^{144} \mathrm{Ce}$ and ${ }^{137} \mathrm{Cs}$ for all three compacts is given in Figure 5-1. The concentration profiles for ${ }^{144} \mathrm{Ce}$ and ${ }^{137} \mathrm{Cs}$ in all three compacts mostly followed the expected decreasing trend toward the outside of the compact due to diffusion from the source term of DTF particles in the compact cores. However, the total inventory of ${ }^{137} \mathrm{Cs}$ was significantly low in the two compacts irradiated at higher temperature. While Compact 1-4 (irradiation TAVA temperature of $929^{\circ} \mathrm{C}$ ) had a total ${ }^{137} \mathrm{Cs}$ inventory of 19.6 particle-equivalents, Compact 8-4 (irradiation TAVA temperature of $1169^{\circ} \mathrm{C}$ ) had a total ${ }^{137} \mathrm{Cs}$ inventory of only 2.6 particle-equivalents and Compact 7-4 (irradiation TAVA temperature of $1319^{\circ} \mathrm{C}$ ) had a total ${ }^{137} \mathrm{Cs}$ inventory of only 4.7 particle-equivalents. This depletion in the higher irradiation temperature compacts was likely due to diffusion of ${ }^{137} \mathrm{Cs}$ out of the compacts. The diffusive depletion of ${ }^{137} \mathrm{Cs}$ from Compacts 8-4 and 7-4 is supported by measurements of the inventory in the capsule rings and hardware for the capsules, which found 60 and 50 particle-equivalents of ${ }^{137} \mathrm{Cs}$ for Capsules 8 and 7 respectively, corresponding to 15 and 12.5 particle-equivalents on average per compact respectively (Stempien et al. 2018a). While less pronounced, the slightly lower ${ }^{144} \mathrm{Ce}$ inventory measured in Compact 7-4 (the hottest compact) also suggested more out-diffusion and release from the compact.

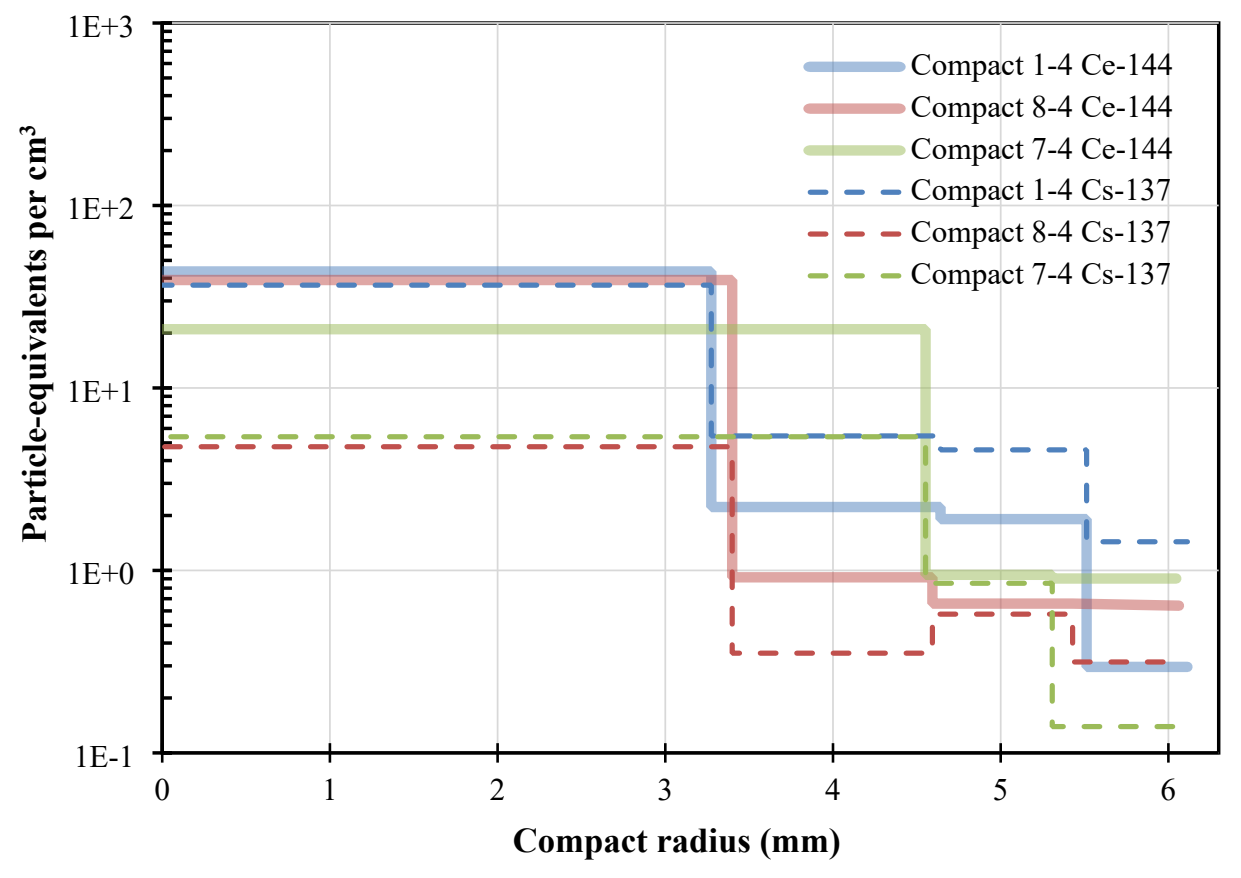

Figure 5-1. Concentration profiles of ${ }^{144} \mathrm{Ce}$ and ${ }^{137} \mathrm{Cs}$ in Compacts 1-4, 8-4, and 7-4. 
A comparison of the concentration profiles for ${ }^{154} \mathrm{Eu}$ and ${ }^{90} \mathrm{Sr}$ for all three compacts is given in Figure 5-2. While the concentration profiles for these isotopes in Compact 1-4 follow the expected progressively decreasing trend associated with diffusion from DTF particles in the compact core, the concentration profiles for Compacts 8-4 and 7-4 were nearly flat. These flat concentration profiles along with the higher total inventories of ${ }^{154} \mathrm{Eu}$ and ${ }^{90} \mathrm{Sr}$ found in the higher irradiation temperature compacts indicate significant temperature dependent release of these isotopes from the driver fuel particles. The total inventories of ${ }^{154} \mathrm{Eu}$ and ${ }^{90} \mathrm{Sr}$ measured in Compact 8-4 were 38.9 and 32.3 particle-equivalents respectively. An additional 11.1 particle-equivalents of ${ }^{154} \mathrm{Eu}$ were measured in the Capsule 8 rings and hardware (Stempien et al. 2018a), bringing the nominal total ${ }^{154} \mathrm{Eu}$ released from particles in Compact 8-4 up to $\sim 42$ particle-equivalents. The total inventories of ${ }^{154} \mathrm{Eu}$ and ${ }^{90} \mathrm{Sr}$ in Compact 7-4 were 52.1 and 41.2 particle-equivalents respectively. An additional 233 particle-equivalents of ${ }^{154} \mathrm{Eu}$ were measured in the Capsule 7 rings and hardware (Stempien et al. 2018a), bringing the nominal total ${ }^{154} \mathrm{Eu}$ released from particles in Compact 7-4 up to $\sim 110$ particle-equivalents. The amount of ${ }^{154} \mathrm{Eu}$ and ${ }^{90} \mathrm{Sr}$ released from driver fuel particles in Compacts 8-4 and 7-4 overwhelmed any diffusion concentration profiles from the 20 DTF particles in the compact cores. The fact that the ${ }^{154} \mathrm{Eu}$ and ${ }^{90} \mathrm{Sr}$ releases through intact $\mathrm{SiC}$ in the driver fuel particles followed similar temperature-dependent trends is consistent with observations from AGR-1 and AGR-2 PIE and safety testing, where releases of these elements tend to track together as a function of temperature (Demkowicz et al. 2015; Stempien et al. 2021). This has been related to the fact that these elements both form carbides in the UCO fuel system.

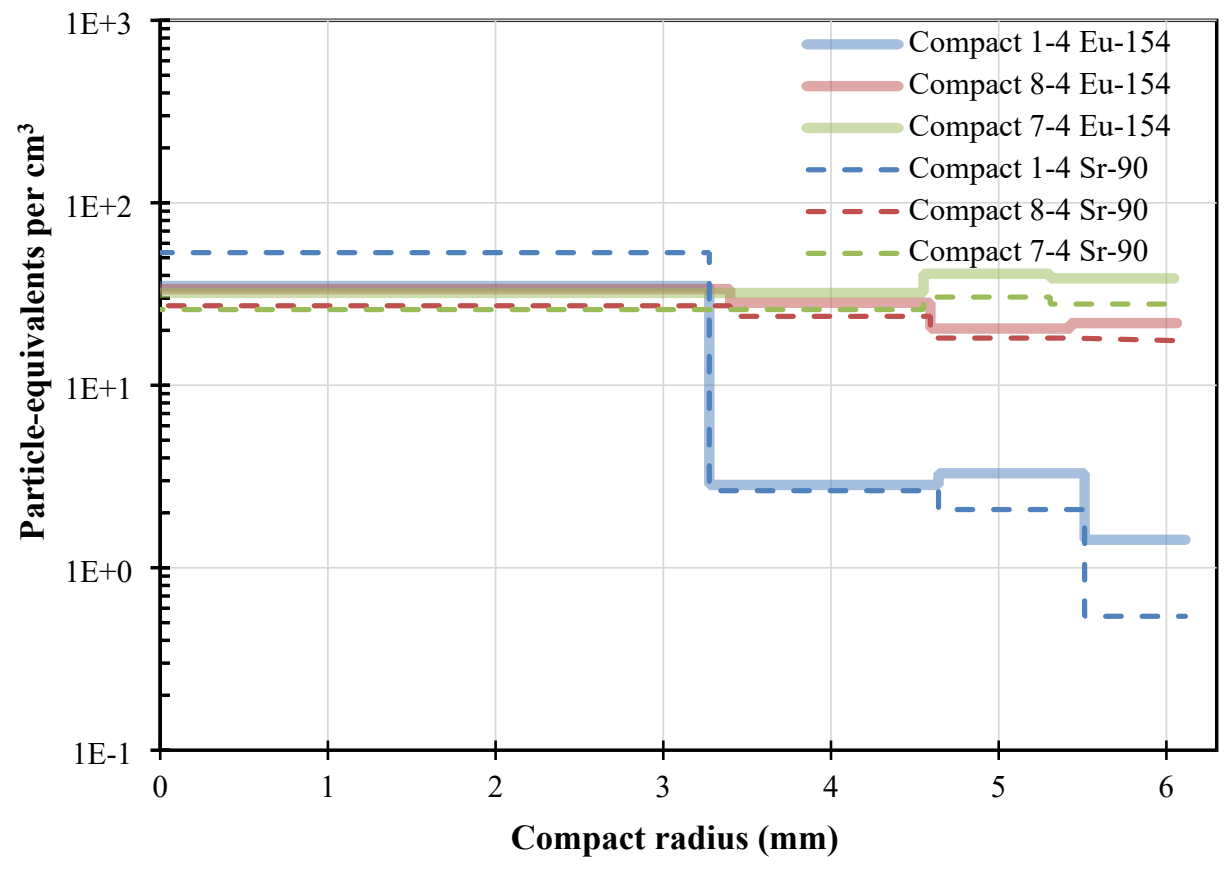

Figure 5-2. Concentration profiles of ${ }^{154} \mathrm{Eu}$ and ${ }^{90} \mathrm{Sr}$ in Compacts 1-4, 8-4, and 7-4.

A comparison of the concentration profiles for ${ }^{235} \mathrm{U}$ and ${ }^{239} \mathrm{Pu}$ for all three compacts is given in Figure 5-3. In Compact 1-4 the concentration profiles for ${ }^{235} \mathrm{U}$ and ${ }^{239} \mathrm{Pu}$ followed the expected decline with each segment moving out from the compact core, and the total inventory of both isotopes (20.1 and 18.7 particle-equivalents respectively) was near the nominal 20 particle-equivalents expected from the DTF particles. In contrast, the concentration profiles of ${ }^{235} \mathrm{U}$ and ${ }^{239} \mathrm{Pu}$ in Compacts 8-4 and 7-4 were relatively flat outside of the compact cores and the total compact inventories for these actinide isotopes were lower than expected. In Compact 8-4, only 17.4 particle-equivalents of ${ }^{235} \mathrm{U}$ and 16.3 particle-equivalents of ${ }^{239} \mathrm{Pu}$ were found, while in Compact 7-4, only 15.1 particle-equivalents of ${ }^{235} \mathrm{U}$ and 15.7 particle- 
equivalents of ${ }^{239} \mathrm{Pu}$ were found. These results suggest that while these actinides were mostly stable in the remnants of the failed DTF particles within the core segments, a temperature-dependent fraction was released from the DTF kernels and diffused out of the compacts. This behavior was similar to and somewhat more advanced compared to what was observed for ${ }^{144} \mathrm{Ce}$ in Compact 7-4.

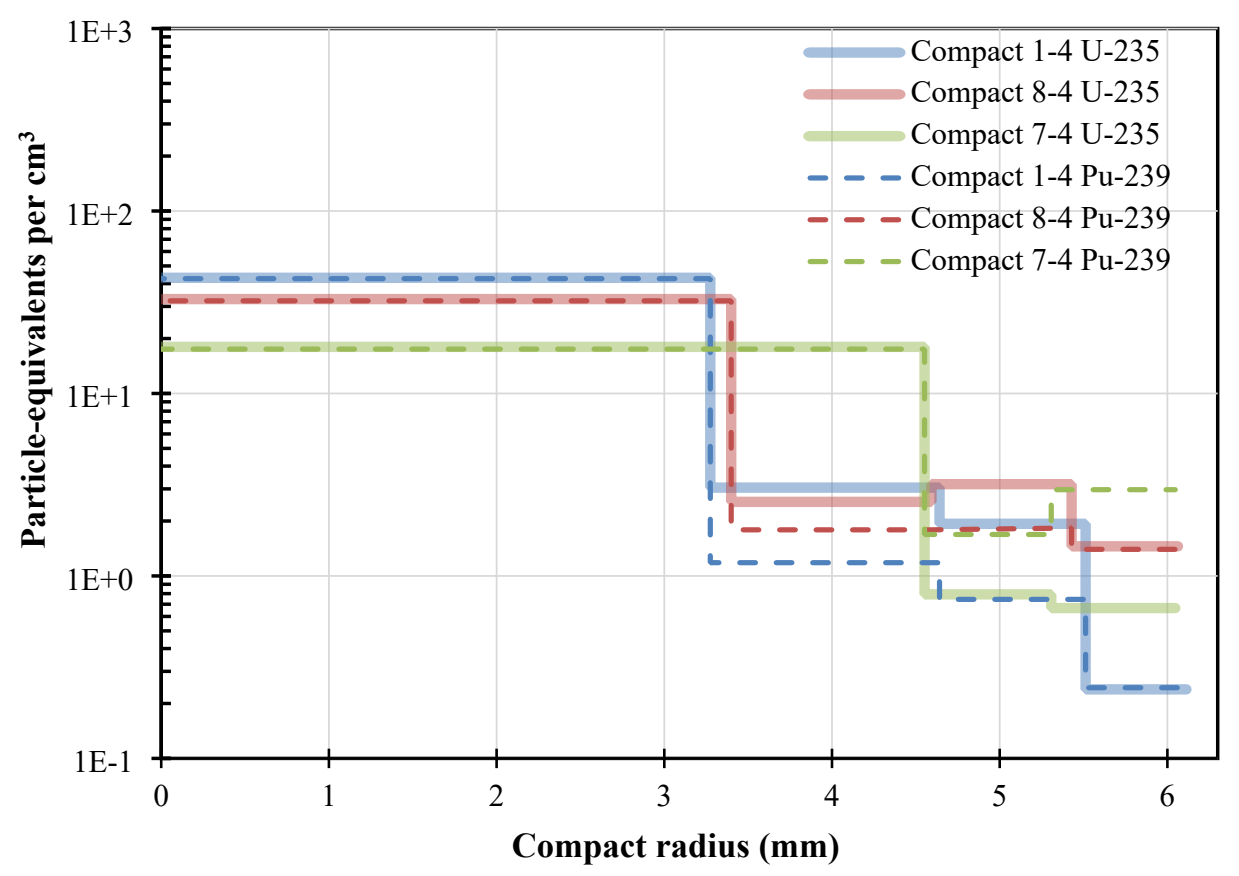

Figure 5-3. Concentration profiles of ${ }^{235} \mathrm{U}$ and ${ }^{239} \mathrm{Pu}$ in Compacts 1-4, 8-4, and 7-4. 


\section{CONCLUSIONS}

Radial deconsolidation and leach-burn-leach were completed on two compacts from the AGR-3/4 irradiation and particles from one of those compacts (Compact 7-4) were examined with the ORNL IMGA. The burnup and irradiation temperatures for both compacts were near the upper end for compacts in the AGR-3/4 irradiation test, with Compact 7-4 at the highest level for both.

Radial deconsolidation was successfully executed on both compacts, with some challenges for Compact 7-4 resulting from separation of the compact from the axle during the third segment. The broken core of Compact 7-4 was successfully deconsolidated using a new deconsolidation apparatus shown in APPENDIX D and the deconsolidated material from the core was combined with the material from the aborted third segment. Uniformity of deconsolidation across the compact was excellent for each segment of both compacts (Figure 3-1 and Figure 4-1). Automated image analysis was applied to randomly oriented photos of each compact after completion of each segment's radial deconsolidation. Two new calibration methods involving the inclusion of a block with a known marked width within the images of the compact were applied. These methods were successful in reducing measurement uncertainty by creating a much longer calibration distance so that minor variations in edge selection for the calibration lines would not significantly influence results. The final calibration method that was adopted utilized a steel block that was placed close to the compact and was thus constrained to the same imaging plane as the compact. This was accomplished by securing the block to the paddle mounting bracket just above the compact.

Leach-burn-leach analysis of material from the deconsolidated compacts was performed using the Soxhlet extraction method used previously for AGR PIE. The isotopic concentration profiles and inventory totals observed from RDLBL for Compacts 8-4 and 7-4 were substantially different from those observed for the lower irradiation temperature Compact 1-4 presented in a prior report. The concentration profile and total inventory of ${ }^{144} \mathrm{Ce}$ in each compact indicated retention of most of the 20 particle-equivalents expected from DTF particles within the compact, with expected diffusion profiles to the outer segments and some temperature dependence in the total amount retained in the compact when compared with Compact 1-4, which was irradiated at significantly lower temperature. Concentration profiles and total inventory of ${ }^{235} \mathrm{U}$ and ${ }^{239} \mathrm{Pu}$ indicated more evident temperature-dependent diffusive release of the actinides from both Compacts 8-4 and 7-4 compared with Compact 1-4, while the total inventory of ${ }^{137} \mathrm{Cs}$ in Compacts 8-4 and 7-4 indicated substantial diffusion out of the compact. Finally, concentration profiles and total inventory of ${ }^{154} \mathrm{Eu}$ and ${ }^{90} \mathrm{Sr}$ in Compacts 8-4 and 7-4 indicated substantial release of both isotopes from driver fuel particles equal to or greater than the nominal source of DTF particles. The release of ${ }^{154} \mathrm{Eu}$ and ${ }^{90} \mathrm{Sr}$ from driver fuel particles was temperature dependent, as the total inventory of both nuclides increased substantially from Compact $1-4\left(929^{\circ} \mathrm{C}\right)$, to Compact $8-4\left(1169^{\circ} \mathrm{C}\right)$, to Compact $7-4\left(1319^{\circ} \mathrm{C}\right)$. 


\section{REFERENCES}

Collin, Blaise P. 2015. AGR-3/4 Irradiation Experimental Plan. INL/PLN-3867, Revision 1. Idaho Falls: Idaho National Laboratory.

Collin, Blaise P. 2016. AGR-3/4 Irradiation Test Final As-Run Report. INL/EXT-15-35550, Revision 1. Idaho Falls: Idaho National Laboratory.

Croff, Allen G. 1983. "ORIGEN2: A Versatile Computer Code for Calculating the Nuclide Compositions and Characteristics of Nuclear Materials." Nucl. Tech. 62: 335-352.

Demkowicz, Paul A., John D. Hunn, Robert N. Morris, Isabella van Rooyen, Tyler J. Gerczak, Jason M. Harp, and Scott A. Ploger. 2015. AGR-1 Post-Irradiation Examination Final Report. INL/EXT-1536407, Idaho National Laboratory.

Demkowicz, Paul A., John D. Hunn, David A. Petti, and Robert N. Morris. 2016. "Key results from irradiation and post-irradiation examination of AGR-1 UCO TRISO fuel." Proc. 8th International Topical Meeting on High Temperature Reactor Technology (HTR-2016). Las Vegas, November 6-10, 2016. Also published in Nucl. Eng. Des. 329: 102-109.

Demkowicz, Paul A. 2017. AGR-3/4 Phase 2 Post-Irradiation Examination Plan. INL/PLN-5382, Revision 0. Idaho Falls: Idaho National Laboratory.

Hawkes, Grant L. 2016. AGR-3/4 Daily As-Run Thermal Analyses. INL/ECAR-2807, Revision 1. Idaho Falls: Idaho National Laboratory.

Helmreich, Grant W., Fred C. Montgomery, and John D. Hunn. 2015. Development of a Radial Deconsolidation Method. ORNL/TM-2015/699, Revision 0. Oak Ridge: Oak Ridge National Laboratory.

Helmreich, Grant W., John D. Hunn, Daniel R. Brown, and Brandon J. Blamer. 2018. "New Method for Analysis of X-ray Computed Tomography Scans of TRISO Fuel Forms." Proc. 9th International Topical Meeting on High Temperature Reactor Technology (HTR-2018). Warsaw, October 8-10, 2018. Also published in Nucl. Eng. Des. 357: 110418.

Hunn, John D., and Richard A. Lowden. 2007. Data Compilation for AGR-3/4 Driver Coated Particle Composite LEU03-09T. ORNL/TM-2007/019, Revision 0. Oak Ridge: Oak Ridge National Laboratory.

Hunn, John D., Michael P. Trammell, and Fred C. Montgomery. 2011. Data Compilation for AGR-3/4 Designed-to-Fail (DTF) Fuel Compact Lot (LEU03-10T-OP2/LEU03-07DTF-OP1)-Z. ORNL/TM2011/124, Revision 0. Oak Ridge: Oak Ridge National Laboratory.

Hunn, John D., Richard A. Lowden, James H. Miller, Brian C. Jolly, Michael P. Trammell, Andrew K. Kercher, Fred C. Montgomery, and Chinthaka M. Silva. 2012. "Fabrication and Characterization of Driver Fuel Particles, Designed-to-Fail Fuel Particles, and Fuel Compacts for the US AGR-3/4 Irradiation Test." Proc. 6th International Topical Meeting on High Temperature Reactor Technology (HTR-2012). Tokyo, October 28-November 1, 2012. Also published in Nucl. Eng. Des. 271: 123130.

Hunn, John D., Robert N. Morris, Charles A. Baldwin, Fred C. Montgomery, Chinthaka M. Silva, and Tyler J. Gerczak. 2012. AGR-1 Irradiated Compact 6-1-1 PIE Report: Evaluation of As-Irradiated Fuel Performance Using Leach Burn Leach, IMGA, Materialography, and X-ray Tomography. ORNL/TM-2012/233, Revision 0. Oak Ridge: Oak Ridge National Laboratory.

Hunn, John D., Robert N. Morris, Charles A. Baldwin, Fred C. Montgomery, Chinthaka M. Silva, and Tyler J. Gerczak. 2013. AGR-1 Irradiated Compact 4-4-2 PIE Report: Evaluation of As-Irradiated 
Fuel Performance with Leach Burn Leach, IMGA, Materialography, and X-ray Tomography. ORNL/TM-2013/236, Revision 0. Oak Ridge: Oak Ridge National Laboratory.

Hunn, John D., Robert N. Morris, Fred C. Montgomery, Tyler J. Gerczak, Darren J. Skitt, Charles A. Baldwin, John A. Dyer, Grant W. Helmreich, Brian D. Eckhart, Zachary M. Burns, Paul A. Demkowicz, and John D. Stempien. 2018. "Post-Irradiation Examination and Safety Testing of US AGR-2 Irradiation Test Compacts." Proc. 9th International Topical Meeting on High Temperature Reactor Technology (HTR-2018). Warsaw, October 8-10, 2018.

Hunn, John D., and Fred C. Montgomery. 2020. Data Acquisition Method: Leach-Burn-Leach Analysis of Irradiated Fuel Compacts Using a Soxhlet Extractor in the 3525 Hot Cell. AGR-CHAR-DAM-37, Revision 4. Oak Ridge: Oak Ridge National Laboratory.

Hunn, John D., Fred C. Montgomery, Darren J. Skitt, and Grant W. Helmreich. 2020. Radial Deconsolidation and Leach-Burn-Leach of AGR-3/4 Compacts 1-4 and 10-4. ORNL/TM-2020/1707, Revision 0. Oak Ridge: Oak Ridge National Laboratory.

Kercher, Andrew K., and John D. Hunn. 2006. Results from ORNL Characterization of Nominal $350 \mu \mathrm{m}$ LEUCO Kernels (LEU03) from the BWXT G73V-20-69303 Composite. ORNL/TM-2006/552, Revision 0. Oak Ridge: Oak Ridge National Laboratory.

Kercher, Andrew K., Brian C. Jolly, Fred C. Montgomery, Chinthaka M. Silva, and John D. Hunn. 2011. Data Compilation for AGR-3/4 Designed-to-Fail (DTF) Fuel Particle Batch LEU03-07DTF. ORNL/TM-2011/109, Revision 0. Oak Ridge: Oak Ridge National Laboratory.

Lowden, Richard A. 2006. Fabrication of Baseline and Variant Particle Fuel for AGR-1. ORNL/CF-2006/02, Revision 0. Oak Ridge: Oak Ridge National Laboratory.

Ludwig, Scott B., and Allen G. Croff. 2002. ORIGEN2.2-Isotope Generation and Depletion Code Matrix Exponential Method. Oak Ridge: Oak Ridge National Laboratory.

Petti, David A., Richard R. Hobbins, James M. Kendall, and John J. Saurwein. 2005. Technical Program Plan for the Advanced Gas Reactor Fuel Development and Qualification Program. INL/EXT-0500465, Revision 1. Idaho Falls: Idaho National Laboratory.

Stempien, John D., Francine J. Rice, Phil L. Winston, and Jason M. Harp. 2016. AGR-3/4 Irradiation Test Train Disassembly and Component Metrology First Look Report. INL/EXT-16-38005, Revision 1. Idaho Falls: Idaho National Laboratory.

Stempien, John D. 2017. Radial Deconsolidation and Leach-Burn-Leach of AGR-3/4 Compact 3-3, 12-1, and 12-3. INL/EXT-17-43182, Revision 0. Idaho Falls: Idaho National Laboratory.

Stempien, John D., Paul A. Demkowicz, Jason M. Harp, and Philip L. Watson. 2018a. AGR-3/4 Experiment Preliminary Mass Balance. INL/EXT-18-46049, Revision 0. Idaho Falls: Idaho National Laboratory.

Stempien, John D., Paul A. Demkowicz, Edward L. Reber, and Cad L. Christensen. 2018b. "Preliminary Results from the First Round of Post-Irradiation Heating Tests of Fuel Compacts from the AGR-3/4 Irradiation." Proc. 9th International Topical Meeting on High Temperature Reactor Technology (HTR-2018). Warsaw, October 8-10, 2018.

Stempien, John D., John D. Hunn, Robert N. Morris, and Paul A. Demkowicz. 2021. AGR-2 TRISO Fuel Post-Irradiation Examination Final Report. INL/EXT-21-64279, Revision 0. Idaho Falls: Idaho National Laboratory.

Sterbentz, James W. 2015. JMOCUP As-Run Daily Depletion Calculation for the AGR-3/4 TRISO Particle Experiment in ATR Northeast Flux Trap. ECAR-2753, Revision 1. Idaho Falls: Idaho National Laboratory. 
X-5 Monte Carlo Team. 2003. MCNP-A General Monte Carlo N-Particle Transport Code. Version 5, Volume I (LA-UR-03-1987) and Volume II (LA-CP-03-0245). Los Alamos: Los Alamos National Laboratory. 
APPENDIX A. RDLBL DATA 



\section{APPENDIX A. RDLBL DATA ${ }^{3}$}

The tables in this appendix document the RDLBL data for select actinides and fission products (both radionuclides and stable nuclides). Data are provided for each primary leach solution in terms of compact fraction and particle-equivalents, as described in Section 0.0 contains the calculated inventory data used to convert the measured values to compact fraction. Particle-equivalents were calculated from the compact fraction by multiplying by an average number of particles per compact of 1,918 .

In some cases, stable and radioactive isotopes of the same element were reported. The compact fraction data for ${ }^{133} \mathrm{Cs}$ and ${ }^{137} \mathrm{Cs}$ tended to agree closely, while ${ }^{134} \mathrm{Cs}$ was often lower. The ${ }^{140} \mathrm{Ce}$ compact fraction tended to track with but somewhat exceed that of ${ }^{144} \mathrm{Ce}$, and the same was true for ${ }^{153} \mathrm{Eu}$ compared with ${ }^{154} \mathrm{Eu}$ and ${ }^{155} \mathrm{Eu}$. It is possible that ${ }^{133} \mathrm{Cs}$ and ${ }^{153} \mathrm{Eu}$ data were elevated by isobaric interferences. The stable

${ }^{109} \mathrm{Ag}$ nuclide provided some indication of silver behavior in the absence of measurable ${ }^{110 \mathrm{~m}} \mathrm{Ag}$, which had gone through too many half-lives prior to analysis. However, previous comparisons have indicated a typically poor agreement between these two isotopes (Hunn et al. 2013).

Appendix Table A-1. Exposed U and Pu detected by RDLBL of AGR-3/4 Compact 8-4 Segment 1

\begin{tabular}{lccccc}
\hline RDLBL Step & ${ }^{235} \mathbf{U}$ & ${ }^{236} \mathbf{U}$ & ${ }^{238} \mathbf{U}$ & ${ }^{239} \mathbf{P u}$ & ${ }^{240} \mathbf{P u}$ \\
\hline \multirow{2}{*}{ Deconsolidation acid } & $1.96 \mathrm{E}-4$ & $1.89 \mathrm{E}-4$ & $2.09 \mathrm{E}-4$ & $7.89 \mathrm{E}-5$ & $5.64 \mathrm{E}-5$ \\
& $(0.375)$ & $(0.363)$ & $(0.401)$ & $(0.151)$ & $(0.108)$ \\
Preburn leach 1 & $3.07 \mathrm{E}-6$ & $4.08 \mathrm{E}-6$ & $1.49 \mathrm{E}-5$ & $1.10 \mathrm{E}-5$ & $1.49 \mathrm{E}-5$ \\
& $(0.0059)$ & $(0.0078)$ & $(0.029)$ & $(0.021)$ & $(0.029)$ \\
Preburn leach 2 & $6.69 \mathrm{E}-7$ & $7.87 \mathrm{E}-7$ & $3.33 \mathrm{E}-6$ & $3.62 \mathrm{E}-6$ & $5.65 \mathrm{E}-6$ \\
& $(0.0013)$ & $(0.0015)$ & $(0.0064)$ & $(0.0069)$ & $(0.011)$ \\
Postburn leach 1 & $1.69 \mathrm{E}-5$ & $1.77 \mathrm{E}-5$ & $2.36 \mathrm{E}-5$ & $1.09 \mathrm{E}-4$ & $1.81 \mathrm{E}-4$ \\
& $(0.032)$ & $(0.034)$ & $(0.045)$ & $(0.209)$ & $(0.347)$ \\
Postburn leach 2 & $9.10 \mathrm{E}-7$ & $1.08 \mathrm{E}-6$ & $5.26 \mathrm{E}-6$ & $6.42 \mathrm{E}-6$ & $9.55 \mathrm{E}-6$ \\
& $(0.0017)$ & $(0.0021)$ & $(0.010)$ & $(0.012)$ & $(0.018)$ \\
\hline \multirow{2}{*}{ Total } & $2.17 \mathrm{E}-4$ & $2.13 \mathrm{E}-4$ & $2.56 \mathrm{E}-4$ & $2.09 \mathrm{E}-4$ & $2.67 \mathrm{E}-4$ \\
& $(0.416)$ & $(0.408)$ & $(0.491)$ & $(0.401)$ & $(0.513)$ \\
\hline
\end{tabular}

Note: Values are reported as compact inventory fractions and particle-equivalents (in parentheses)

\footnotetext{
${ }^{3}$ This appendix is a revised version of a similar appendix in a previous AGR-3/4 PIE report (Hunn and Montgomery, 2020) and is duplicated herein to maintain a consistent format in documenting similar data.
} 
Appendix Table A-2. Exposed U and Pu detected by RDLBL of AGR-3/4 Compact 8-4 Segment 2

\begin{tabular}{lccccc}
\hline RDLBL Step & ${ }^{235} \mathbf{U}$ & ${ }^{\mathbf{2 3 6}} \mathbf{U}$ & ${ }^{238} \mathbf{U}$ & ${ }^{239} \mathbf{P u}$ & ${ }^{\mathbf{2 4 0}} \mathbf{P u}$ \\
\hline \multirow{2}{*}{ Deconsolidation acid } & $5.20 \mathrm{E}-4$ & $4.91 \mathrm{E}-4$ & $5.08 \mathrm{E}-4$ & $2.13 \mathrm{E}-4$ & $1.52 \mathrm{E}-4$ \\
& $(0.998)$ & $(0.942)$ & $(0.975)$ & $(0.409)$ & $(0.291)$ \\
Preburn leach 1 & $1.22 \mathrm{E}-5$ & $1.16 \mathrm{E}-5$ & $1.98 \mathrm{E}-5$ & $1.41 \mathrm{E}-5$ & $1.70 \mathrm{E}-5$ \\
& $(0.023)$ & $(0.022)$ & $(0.038)$ & $(0.027)$ & $(0.033)$ \\
Preburn leach 2 & $1.45 \mathrm{E}-6$ & $1.17 \mathrm{E}-6$ & $5.23 \mathrm{E}-6$ & $4.14 \mathrm{E}-6$ & $6.30 \mathrm{E}-6$ \\
& $(0.0028)$ & $(0.0022)$ & $(0.010)$ & $(0.0079)$ & $(0.012)$ \\
Postburn leach 1 & $1.16 \mathrm{E}-5$ & $1.23 \mathrm{E}-5$ & $2.15 \mathrm{E}-5$ & $7.75 \mathrm{E}-5$ & $1.22 \mathrm{E}-4$ \\
& $(0.022)$ & $(0.024)$ & $(0.041)$ & $(0.149)$ & $(0.235)$ \\
Postburn leach 2 & $9.22 \mathrm{E}-7$ & $1.50 \mathrm{E}-6$ & $9.12 \mathrm{E}-6$ & $5.43 \mathrm{E}-6$ & $8.24 \mathrm{E}-6$ \\
& $(0.0018)$ & $(0.0029)$ & $(0.017)$ & $(0.010)$ & $(0.016)$ \\
\hline \multirow{2}{*}{ Total } & $5.47 \mathrm{E}-4$ & $5.18 \mathrm{E}-4$ & $5.64 \mathrm{E}-4$ & $3.14 \mathrm{E}-4$ & $3.06 \mathrm{E}-4$ \\
& $(1.048)$ & $(0.993)$ & $(1.082)$ & $(0.603)$ & $(0.586)$ \\
\hline
\end{tabular}

Note: Values are reported as compact inventory fractions and particle-equivalents (in parentheses)

Appendix Table A-3. Exposed U and Pu detected by RDLBL of AGR-3/4 Compact 8-4 Segment 3

\begin{tabular}{lccccc}
\hline RDLBL Step & ${ }^{235} \mathbf{U}$ & ${ }^{236} \mathbf{U}$ & ${ }^{238} \mathbf{U}$ & ${ }^{239} \mathbf{P u}$ & ${ }^{\mathbf{2 4 0}} \mathbf{P u}$ \\
\hline \multirow{2}{*}{ Deconsolidation acid } & $4.69 \mathrm{E}-4$ & $4.27 \mathrm{E}-4$ & $4.95 \mathrm{E}-4$ & $1.99 \mathrm{E}-4$ & $1.35 \mathrm{E}-4$ \\
& $(0.900)$ & $(0.818)$ & $(0.950)$ & $(0.382)$ & $(0.259)$ \\
Preburn leach 1 & $8.77 \mathrm{E}-6$ & $8.62 \mathrm{E}-6$ & $1.18 \mathrm{E}-5$ & $1.22 \mathrm{E}-5$ & $1.26 \mathrm{E}-5$ \\
& $(0.017)$ & $(0.017)$ & $(0.023)$ & $(0.023)$ & $(0.024)$ \\
Preburn leach 2 & $7.31 \mathrm{E}-7$ & $8.35 \mathrm{E}-7$ & $3.63 \mathrm{E}-6$ & $3.14 \mathrm{E}-6$ & $5.10 \mathrm{E}-6$ \\
& $(0.0014)$ & $(0.0016)$ & $(0.007)$ & $(0.006)$ & $(0.0098)$ \\
Postburn leach 1 & $1.85 \mathrm{E}-5$ & $1.83 \mathrm{E}-5$ & $2.33 \mathrm{E}-5$ & $1.30 \mathrm{E}-4$ & $2.25 \mathrm{E}-4$ \\
& $(0.035)$ & $(0.035)$ & $(0.045)$ & $(0.250)$ & $(0.431)$ \\
Postburn leach 2 & $6.87 \mathrm{E}-7$ & $7.69 \mathrm{E}-7$ & $3.63 \mathrm{E}-6$ & $4.60 \mathrm{E}-6$ & $7.85 \mathrm{E}-6$ \\
& $(0.0013)$ & $(0.0015)$ & $(0.007)$ & $(0.0088)$ & $(0.015)$ \\
\hline \multirow{2}{*}{ Total } & $4.98 \mathrm{E}-4$ & $4.55 \mathrm{E}-4$ & $5.38 \mathrm{E}-4$ & $3.50 \mathrm{E}-4$ & $3.85 \mathrm{E}-4$ \\
& $(0.955)$ & $(0.873)$ & $(1.031)$ & $(0.671)$ & $(0.739)$ \\
\hline
\end{tabular}

Note: Values are reported as compact inventory fractions and particle-equivalents (in parentheses) 
Appendix Table A-4. Exposed U and Pu detected by RDLBL of AGR-3/4 Compact 8-4 Segment 4

\begin{tabular}{lccccc}
\hline RDLBL Step & ${ }^{235} \mathbf{U}$ & ${ }^{\mathbf{2 3 6}} \mathbf{U}$ & ${ }^{\mathbf{2 3 8}} \mathbf{U}$ & ${ }^{\mathbf{2 3 9}} \mathbf{P u}$ & ${ }^{\mathbf{2 4 0}} \mathbf{P u}$ \\
\hline \multirow{2}{*}{ Deconsolidation acid } & $7.70 \mathrm{E}-3$ & $7.26 \mathrm{E}-3$ & $7.29 \mathrm{E}-3$ & $5.47 \mathrm{E}-3$ & $4.78 \mathrm{E}-3$ \\
& $(14.775)$ & $(13.925)$ & $(13.988)$ & $(10.500)$ & $(9.161)$ \\
Preburn leach 1 & $2.78 \mathrm{E}-5$ & $2.76 \mathrm{E}-5$ & $3.00 \mathrm{E}-5$ & $3.39 \mathrm{E}-4$ & $5.29 \mathrm{E}-4$ \\
& $(0.053)$ & $(0.053)$ & $(0.058)$ & $(0.650)$ & $(1.015)$ \\
Preburn leach 2 & $5.53 \mathrm{E}-6$ & $5.02 \mathrm{E}-6$ & $6.37 \mathrm{E}-6$ & $5.23 \mathrm{E}-5$ & $7.48 \mathrm{E}-5$ \\
& $(0.011)$ & $(0.0096)$ & $(0.012)$ & $(0.100)$ & $(0.144)$ \\
Postburn leach 1 & $5.11 \mathrm{E}-5$ & $4.90 \mathrm{E}-5$ & $5.90 \mathrm{E}-5$ & $1.74 \mathrm{E}-3$ & $2.45 \mathrm{E}-3$ \\
& $(0.098)$ & $(0.094)$ & $(0.113)$ & $(3.345)$ & $(4.706)$ \\
Postburn leach 2 & $6.36 \mathrm{E}-7$ & $6.73 \mathrm{E}-7$ & $1.52 \mathrm{E}-6$ & $1.12 \mathrm{E}-5$ & $1.63 \mathrm{E}-5$ \\
& $(0.0012)$ & $(0.0013)$ & $(0.0029)$ & $(0.022)$ & $(0.031)$ \\
\hline \multirow{2}{*}{ Total } & $7.79 \mathrm{E}-3$ & $7.34 \mathrm{E}-3$ & $7.39 \mathrm{E}-3$ & $7.62 \mathrm{E}-3$ & $7.85 \mathrm{E}-3$ \\
& $(14.938)$ & $(14.083)$ & $(14.174)$ & $(14.618)$ & $(15.058)$ \\
\hline
\end{tabular}

Note: Values are reported as compact inventory fractions and particle-equivalents (in parentheses)

Appendix Table A-5. Exposed U and Pu detected by RDLBL of AGR-3/4 Compact 7-4 Segment 1

\begin{tabular}{lccccc}
\hline RDLBL Step & ${ }^{235} \mathbf{U}$ & ${ }^{236} \mathbf{U}$ & ${ }^{238} \mathbf{U}$ & ${ }^{239} \mathbf{P u}$ & ${ }^{240} \mathbf{P u}$ \\
\hline \multirow{2}{*}{ Deconsolidation acid } & $5.69 \mathrm{E}-4$ & $5.80 \mathrm{E}-4$ & $5.56 \mathrm{E}-4$ & $6.03 \mathrm{E}-4$ & $6.16 \mathrm{E}-4$ \\
& $(1.091)$ & $(1.113)$ & $(1.067)$ & $(1.157)$ & $(1.182)$ \\
Preburn leach 1 & $5.80 \mathrm{E}-6$ & $5.72 \mathrm{E}-6$ & $7.87 \mathrm{E}-6$ & $1.27 \mathrm{E}-5$ & $1.73 \mathrm{E}-5$ \\
& $(0.011)$ & $(0.011)$ & $(0.015)$ & $(0.024)$ & $(0.033)$ \\
Preburn leach 2 & $7.52 \mathrm{E}-7$ & $6.04 \mathrm{E}-7$ & $1.44 \mathrm{E}-6$ & $3.78 \mathrm{E}-6$ & $6.35 \mathrm{E}-6$ \\
& $(0.0014)$ & $(0.0012)$ & $(0.0028)$ & $(0.0073)$ & $(0.012)$ \\
Postburn matrix leach 1 & $2.16 \mathrm{E}-5$ & $3.40 \mathrm{E}-5$ & $2.08 \mathrm{E}-4$ & $9.44 \mathrm{E}-5$ & $1.39 \mathrm{E}-4$ \\
& $(0.041)$ & $(0.065)$ & $(0.400)$ & $(0.181)$ & $(0.266)$ \\
Postburn matrix leach 2 & $4.59 \mathrm{E}-7$ & $6.67 \mathrm{E}-7$ & $3.75 \mathrm{E}-6$ & $2.03 \mathrm{E}-6$ & $2.75 \mathrm{E}-6$ \\
& $(0.0009)$ & $(0.0013)$ & $(0.0072)$ & $(0.0039)$ & $(0.0053)$ \\
Postburn particle leach 1 ${ }^{a}$ & $3.79 \mathrm{E}-5$ & $1.06 \mathrm{E}-4$ & $3.94 \mathrm{E}-4$ & $3.09 \mathrm{E}-4$ & $5.35 \mathrm{E}-4$ \\
& $(0.073)$ & $(0.204)$ & $(0.755)$ & $(0.592)$ & $(1.025)$ \\
Postburn particle leach 2 ${ }^{a}$ & $8.52 \mathrm{E}-7$ & $1.47 \mathrm{E}-6$ & $5.82 \mathrm{E}-6$ & $7.75 \mathrm{E}-6$ & $1.22 \mathrm{E}-5$ \\
& $(0.0016)$ & $(0.0028)$ & $(0.011)$ & $(0.015)$ & $(0.023)$ \\
\hline \multirow{2}{*}{ Total } & $6.36 \mathrm{E}-4$ & $7.29 \mathrm{E}-4$ & $1.18 \mathrm{E}-3$ & $1.03 \mathrm{E}-3$ & $1.33 \mathrm{E}-3$ \\
& $(1.220)$ & $(1.398)$ & $(2.258)$ & $(1.980)$ & $(2.548)$ \\
\hline
\end{tabular}

Note: Values are reported as compact inventory fractions and particle-equivalents (in parentheses) ${ }^{a}$ Postburn particle leach data were scaled to account for $\sim 11 \%$ particle population withheld from postburn analysis 
Appendix Table A-6. Exposed U and Pu detected by RDLBL of AGR-3/4 Compact 7-4 Segment 2

\begin{tabular}{lccccc}
\hline RDLBL Step & ${ }^{235} \mathbf{U}$ & ${ }^{236} \mathbf{U}$ & ${ }^{238} \mathbf{U}$ & ${ }^{239} \mathbf{P u}$ & ${ }^{240} \mathbf{P u}$ \\
\hline Deconsolidation acid & $7.11 \mathrm{E}-5$ & $6.92 \mathrm{E}-5$ & $7.57 \mathrm{E}-5$ & $2.73 \mathrm{E}-5$ & $3.11 \mathrm{E}-5$ \\
& $(0.136)$ & $(0.133)$ & $(0.145)$ & $(0.052)$ & $(0.060)$ \\
Preburn leach 1 & $1.69 \mathrm{E}-6$ & $1.57 \mathrm{E}-6$ & $5.33 \mathrm{E}-6$ & $4.38 \mathrm{E}-6$ & $7.57 \mathrm{E}-6$ \\
& $(0.0032)$ & $(0.003)$ & $(0.010)$ & $(0.0084)$ & $(0.015)$ \\
Preburn leach 2 & $5.01 \mathrm{E}-7$ & $3.18 \mathrm{E}-7$ & $1.02 \mathrm{E}-6$ & $2.58 \mathrm{E}-6$ & $3.81 \mathrm{E}-6$ \\
& $(0.001)$ & $(0.0006)$ & $(0.002)$ & $(0.0049)$ & $(0.0073)$ \\
Postburn matrix leach 1 & $6.85 \mathrm{E}-6$ & $7.17 \mathrm{E}-6$ & $2.50 \mathrm{E}-5$ & $1.25 \mathrm{E}-5$ & $1.86 \mathrm{E}-5$ \\
& $(0.013)$ & $(0.014)$ & $(0.048)$ & $(0.024)$ & $(0.036)$ \\
Postburn matrix leach 2 & $5.00 \mathrm{E}-7$ & $5.73 \mathrm{E}-7$ & $2.24 \mathrm{E}-6$ & $1.09 \mathrm{E}-6$ & $1.49 \mathrm{E}-6$ \\
& $(0.001)$ & $(0.0011)$ & $(0.0043)$ & $(0.0021)$ & $(0.0029)$ \\
Postburn particle leach 1 ${ }^{a}$ & $3.79 \mathrm{E}-5$ & $4.68 \mathrm{E}-5$ & $1.92 \mathrm{E}-4$ & $1.99 \mathrm{E}-4$ & $3.44 \mathrm{E}-4$ \\
& $(0.073)$ & $(0.090)$ & $(0.369)$ & $(0.381)$ & $(0.659)$ \\
Postburn particle leach 2 ${ }^{a}$ & $2.63 \mathrm{E}-6$ & $3.63 \mathrm{E}-6$ & $1.88 \mathrm{E}-5$ & $1.09 \mathrm{E}-5$ & $1.65 \mathrm{E}-5$ \\
& $(0.0051)$ & $(0.007)$ & $(0.036)$ & $(0.021)$ & $(0.032)$ \\
\hline
\end{tabular}

Appendix Table A-7. Exposed U and Pu detected by RDLBL of AGR-3/4 Compact 7-4 Segment 3

\begin{tabular}{lccccc}
\hline RDLBL Step & ${ }^{235} \mathbf{U}$ & ${ }^{236} \mathbf{U}$ & ${ }^{238} \mathbf{U}$ & ${ }^{239} \mathbf{P u}$ & ${ }^{\mathbf{2 4 0}} \mathbf{P u}$ \\
\hline \multirow{2}{*}{ Deconsolidation acid } & $7.46 \mathrm{E}-3$ & $7.15 \mathrm{E}-3$ & $7.17 \mathrm{E}-3$ & $5.05 \mathrm{E}-3$ & $4.38 \mathrm{E}-3$ \\
& $(14.300)$ & $(13.723)$ & $(13.752)$ & $(9.682)$ & $(8.401)$ \\
Preburn leach 1 & $1.05 \mathrm{E}-4$ & $1.03 \mathrm{E}-4$ & $1.08 \mathrm{E}-4$ & $4.67 \mathrm{E}-4$ & $6.28 \mathrm{E}-4$ \\
& $(0.202)$ & $(0.197)$ & $(0.207)$ & $(0.896)$ & $(1.204)$ \\
Preburn leach 2 & $4.12 \mathrm{E}-6$ & $4.15 \mathrm{E}-6$ & $5.18 \mathrm{E}-6$ & $4.55 \mathrm{E}-5$ & $6.58 \mathrm{E}-5$ \\
& $(0.0079)$ & $(0.008)$ & $(0.0099)$ & $(0.087)$ & $(0.126)$ \\
Postburn matrix leach 1 & $3.56 \mathrm{E}-5$ & $3.84 \mathrm{E}-5$ & $8.06 \mathrm{E}-5$ & $6.96 \mathrm{E}-4$ & $1.14 \mathrm{E}-3$ \\
& $(0.068)$ & $(0.074)$ & $(0.155)$ & $(1.336)$ & $(2.178)$ \\
Postburn matrix leach 2 & $4.35 \mathrm{E}-7$ & $4.67 \mathrm{E}-7$ & $1.08 \mathrm{E}-6$ & $7.24 \mathrm{E}-6$ & $1.23 \mathrm{E}-5$ \\
& $(0.0008)$ & $(0.0009)$ & $(0.0021)$ & $(0.014)$ & $(0.024)$ \\
Postburn particle leach 1 ${ }^{a}$ & $4.45 \mathrm{E}-5$ & $4.40 \mathrm{E}-5$ & $4.92 \mathrm{E}-5$ & $1.13 \mathrm{E}-3$ & $1.97 \mathrm{E}-3$ \\
& $(0.085)$ & $(0.084)$ & $(0.094)$ & $(2.170)$ & $(3.771)$ \\
Postburn particle leach 2 ${ }^{a}$ & $1.47 \mathrm{E}-6$ & $1.70 \mathrm{E}-6$ & $7.71 \mathrm{E}-6$ & $3.70 \mathrm{E}-5$ & $7.78 \mathrm{E}-5$ \\
& $(0.0028)$ & $(0.0033)$ & $(0.015)$ & $(0.071)$ & $(0.149)$ \\
\hline \multirow{2}{*}{ Total } & $7.14 \mathrm{E}-3$ & $6.85 \mathrm{E}-3$ & $6.90 \mathrm{E}-3$ & $7.22 \mathrm{E}-3$ & $8.10 \mathrm{E}-3$ \\
& $(13.689)$ & $(13.146)$ & $(13.236)$ & $(13.853)$ & $(15.545)$ \\
\hline
\end{tabular}

Note: Values are reported as compact inventory fractions and particle-equivalents (in parentheses)

${ }^{a}$ Postburn particle leach data were scaled to account for $\sim 11 \%$ particle population withheld from postburn analysis 
Appendix Table A-8. Typically tracked beta/gamma-emitting fission products detected by RDLBL of AGR-3/4 Compact 8-4 Segment 1

\begin{tabular}{|c|c|c|c|c|c|c|c|c|c|}
\hline RDLBL Step & ${ }^{90} \mathrm{Sr}$ & ${ }^{106} \mathrm{Ru}$ & ${ }^{110 m} \mathrm{Ag}$ & ${ }^{125} \mathrm{Sb}$ & ${ }^{134} \mathrm{Cs}$ & ${ }^{137} \mathrm{Cs}$ & ${ }^{144} \mathrm{Ce}$ & ${ }^{154} \mathbf{E u}$ & ${ }^{155} \mathbf{E u}$ \\
\hline Deconsolidation acid & $\begin{array}{c}6.73 \mathrm{E}-4 \\
(1.290)\end{array}$ & $\begin{array}{c}6.62 \mathrm{E}-5 \\
(0.127)\end{array}$ & $\begin{array}{c}<6.2 \mathrm{E}-3 \\
<(11.925)\end{array}$ & $\begin{array}{c}4.84 \mathrm{E}-5 \\
(0.093)\end{array}$ & $\begin{array}{c}7.77 \mathrm{E}-6 \\
(0.015)\end{array}$ & $\begin{array}{c}3.10 \mathrm{E}-5 \\
(0.060)\end{array}$ & $\begin{array}{c}2.41 \mathrm{E}-5 \\
(0.046)\end{array}$ & $\begin{array}{c}6.27 \mathrm{E}-4 \\
(1.203)\end{array}$ & $\begin{array}{c}7.41 \mathrm{E}-4 \\
(1.422)\end{array}$ \\
\hline Preburn leach 1 & $\begin{array}{c}2.04 \mathrm{E}-4 \\
(0.392)\end{array}$ & $\begin{array}{l}<1.7 \mathrm{E}-5 \\
<(0.032)\end{array}$ & $\begin{array}{c}<6.0 \mathrm{E}-3 \\
<(11.432)\end{array}$ & $\begin{array}{l}1.33 \mathrm{E}-5 \\
(0.025)\end{array}$ & $\begin{array}{c}8.16 \mathrm{E}-7 \\
(0.0016)\end{array}$ & $\begin{array}{c}7.84 \mathrm{E}-6 \\
(0.015)\end{array}$ & $\begin{array}{l}<2.5 \mathrm{E}-6 \\
<(0.0047)\end{array}$ & $\begin{array}{c}5.12 \mathrm{E}-4 \\
(0.982)\end{array}$ & $\begin{array}{c}5.74 \mathrm{E}-4 \\
(1.100)\end{array}$ \\
\hline Preburn leach 2 & $\begin{array}{c}2.70 \mathrm{E}-5 \\
(0.052)\end{array}$ & $\begin{array}{l}<1.2 \mathrm{E}-5 \\
<(0.023)\end{array}$ & $\begin{array}{l}<4.0 \mathrm{E}-3 \\
<(7.753)\end{array}$ & $\begin{array}{l}<8.7 \mathrm{E}-6 \\
<(0.017)\end{array}$ & $\begin{array}{c}<3.6 \mathrm{E}-7 \\
<(0.0007)\end{array}$ & $\begin{array}{c}1.11 \mathrm{E}-6 \\
(0.0021)\end{array}$ & $\begin{array}{l}<5.4 \mathrm{E}-6 \\
<(0.010)\end{array}$ & $\begin{array}{l}7.39 \mathrm{E}-5 \\
(0.142)\end{array}$ & $\begin{array}{c}8.49 \mathrm{E}-5 \\
(0.163)\end{array}$ \\
\hline Postburn leach 1 & $\begin{array}{l}1.70 \mathrm{E}-3 \\
(3.266)\end{array}$ & $\begin{array}{l}<4.7 \mathrm{E}-5 \\
<(0.090)\end{array}$ & $\begin{array}{c}<1.6 \mathrm{E}-2 \\
<(31.189)\end{array}$ & $\begin{array}{l}<3.0 \mathrm{E}-5 \\
<(0.057)\end{array}$ & $\begin{array}{c}6.76 \mathrm{E}-7 \\
(0.0013)\end{array}$ & $\begin{array}{c}4.63 \mathrm{E}-6 \\
(0.0089)\end{array}$ & $\begin{array}{c}7.17 \mathrm{E}-5 \\
(0.137)\end{array}$ & $\begin{array}{c}2.04 \mathrm{E}-3 \\
(3.912)\end{array}$ & $\begin{array}{c}2.20 \mathrm{E}-3 \\
(4.221)\end{array}$ \\
\hline Postburn leach 2 & $\begin{array}{l}1.57 \mathrm{E}-5 \\
(0.030)\end{array}$ & $\begin{array}{l}<1.0 \mathrm{E}-5 \\
<(0.019)\end{array}$ & $\begin{array}{l}<3.3 \mathrm{E}-3 \\
<(6.416)\end{array}$ & $\begin{array}{l}<8.3 \mathrm{E}-6 \\
<(0.016)\end{array}$ & $\begin{array}{c}<3.0 \mathrm{E}-7 \\
<(0.0006)\end{array}$ & $\begin{array}{c}2.50 \mathrm{E}-6 \\
(0.0048)\end{array}$ & $\begin{array}{c}<4.4 \mathrm{E}-6 \\
<(0.0084)\end{array}$ & $\begin{array}{l}1.82 \mathrm{E}-5 \\
(0.035)\end{array}$ & $\begin{array}{c}2.24 \mathrm{E}-5 \\
(0.043)\end{array}$ \\
\hline Total & $\begin{array}{c}2.62 \mathrm{E}-3 \\
(5.030)\end{array}$ & $\begin{array}{c}6.62 \mathrm{E}-5 \\
(0.127)\end{array}$ & $\begin{array}{c}0.00 \mathrm{E}+0 \\
(0.000)\end{array}$ & $\begin{array}{c}6.16 \mathrm{E}-5 \\
(0.118)\end{array}$ & $\begin{array}{c}9.27 \mathrm{E}-6 \\
(0.018)\end{array}$ & $\begin{array}{c}4.71 \mathrm{E}-5 \\
(0.090)\end{array}$ & $\begin{array}{c}9.58 \mathrm{E}-5 \\
(0.184)\end{array}$ & $\begin{array}{c}3.27 \mathrm{E}-3 \\
(6.274)\end{array}$ & $\begin{array}{c}3.62 \mathrm{E}-3 \\
(6.949)\end{array}$ \\
\hline
\end{tabular}

Note: Chemical separation and beta analysis were used to measure ${ }^{90} \mathrm{Sr}$; other nuclides were measured by gamma spectrometry

Note: Values are reported as compact inventory fractions and particle-equivalents (in parentheses)

Note: A less-than value indicates that the concentration in the leachate was below the minimum detectable limit; these values are not included in the totals 
Appendix Table A-9. Typically tracked beta/gamma-emitting fission products detected by RDLBL of AGR-3/4 Compact 8-4 Segment 2

\begin{tabular}{|c|c|c|c|c|c|c|c|c|c|}
\hline RDLBL Step & ${ }^{90} \mathrm{Sr}$ & ${ }^{106} \mathbf{R u}$ & ${ }^{110 m} \mathrm{Ag}$ & ${ }^{125} \mathrm{Sb}$ & ${ }^{134} \mathrm{Cs}$ & ${ }^{137} \mathrm{Cs}$ & ${ }^{144} \mathrm{Ce}$ & ${ }^{154} \mathbf{E u}$ & ${ }^{155} \mathbf{E u}$ \\
\hline Deconsolidation acid & $\begin{array}{c}7.79 \mathrm{E}-4 \\
(1.494)\end{array}$ & $\begin{array}{c}1.66 \mathrm{E}-4 \\
(0.319)\end{array}$ & $\begin{array}{c}<6.3 \mathrm{E}-3 \\
<(12.170)\end{array}$ & $\begin{array}{c}3.20 \mathrm{E}-5 \\
(0.061)\end{array}$ & $\begin{array}{c}2.10 \mathrm{E}-5 \\
(0.040)\end{array}$ & $\begin{array}{c}8.25 \mathrm{E}-5 \\
(0.158)\end{array}$ & $\begin{array}{c}5.66 \mathrm{E}-5 \\
(0.109)\end{array}$ & $\begin{array}{c}6.34 \mathrm{E}-4 \\
(1.216)\end{array}$ & $\begin{array}{c}7.11 \mathrm{E}-4 \\
(1.364)\end{array}$ \\
\hline Preburn leach 1 & $\begin{array}{c}2.55 \mathrm{E}-4 \\
(0.489)\end{array}$ & $\begin{array}{c}2.23 \mathrm{E}-5 \\
(0.043)\end{array}$ & $\begin{array}{c}<6.6 \mathrm{E}-3 \\
<(12.737)\end{array}$ & $\begin{array}{c}3.05 \mathrm{E}-5 \\
(0.058)\end{array}$ & $\begin{array}{c}1.97 \mathrm{E}-6 \\
(0.0038)\end{array}$ & $\begin{array}{c}7.11 \mathrm{E}-6 \\
(0.014)\end{array}$ & $\begin{array}{c}6.43 \mathrm{E}-6 \\
(0.012)\end{array}$ & $\begin{array}{c}5.61 \mathrm{E}-4 \\
(1.075)\end{array}$ & $\begin{array}{c}6.92 \mathrm{E}-4 \\
(1.328)\end{array}$ \\
\hline Preburn leach 2 & $\begin{array}{c}4.29 \mathrm{E}-5 \\
(0.082)\end{array}$ & $\begin{array}{l}<1.0 \mathrm{E}-5 \\
<(0.019)\end{array}$ & $\begin{array}{l}<3.7 \mathrm{E}-3 \\
<(7.031)\end{array}$ & $\begin{array}{c}5.05 \mathrm{E}-6 \\
(0.0097)\end{array}$ & $\begin{array}{c}5.05 \mathrm{E}-7 \\
(0.001)\end{array}$ & $\begin{array}{c}2.33 \mathrm{E}-6 \\
(0.0045)\end{array}$ & $\begin{array}{l}<4.2 \mathrm{E}-6 \\
<(0.008)\end{array}$ & $\begin{array}{l}1.34 \mathrm{E}-4 \\
(0.257)\end{array}$ & $\begin{array}{c}1.56 \mathrm{E}-4 \\
(0.299)\end{array}$ \\
\hline Postburn leach 1 & $\begin{array}{c}2.03 \mathrm{E}-3 \\
(3.889)\end{array}$ & $\begin{array}{l}<3.3 \mathrm{E}-5 \\
<(0.064)\end{array}$ & $\begin{array}{c}<1.1 \mathrm{E}-2 \\
<(20.377)\end{array}$ & $\begin{array}{c}4.13 \mathrm{E}-5 \\
(0.079)\end{array}$ & $\begin{array}{c}<1.3 \mathrm{E}-6 \\
<(0.0025)\end{array}$ & $\begin{array}{c}4.23 \mathrm{E}-6 \\
(0.0081)\end{array}$ & $\begin{array}{c}5.00 \mathrm{E}-5 \\
(0.096)\end{array}$ & $\begin{array}{c}2.18 \mathrm{E}-3 \\
(4.173)\end{array}$ & $\begin{array}{c}2.46 \mathrm{E}-3 \\
(4.719)\end{array}$ \\
\hline Postburn leach 2 & $\begin{array}{c}1.01 \mathrm{E}-5 \\
(0.019) \\
\end{array}$ & $\begin{array}{l}<6.7 \mathrm{E}-6 \\
<(0.013)\end{array}$ & $\begin{array}{l}<2.2 \mathrm{E}-3 \\
<(4.147)\end{array}$ & $\begin{array}{l}<6.26 \mathrm{E}-6 \\
<(0.012)\end{array}$ & $\begin{array}{c}<1.5 \mathrm{E}-7 \\
<(0.0003)\end{array}$ & $\begin{array}{c}2.70 \mathrm{E}-6 \\
(0.0052)\end{array}$ & $\begin{array}{c}<2.8 \mathrm{E}-6 \\
<(0.0054)\end{array}$ & $\begin{array}{c}8.65 \mathrm{E}-6 \\
(0.017)\end{array}$ & $\begin{array}{c}1.02 \mathrm{E}-5 \\
(0.019)\end{array}$ \\
\hline Total & $\begin{array}{c}3.11 \mathrm{E}-3 \\
(5.974)\end{array}$ & $\begin{array}{l}1.89 \mathrm{E}-4 \\
(0.362)\end{array}$ & $\begin{array}{c}0.00 \mathrm{E}+0 \\
(0.000)\end{array}$ & $\begin{array}{l}1.09 \mathrm{E}-4 \\
(0.209)\end{array}$ & $\begin{array}{c}2.35 \mathrm{E}-5 \\
(0.045)\end{array}$ & $\begin{array}{c}9.88 \mathrm{E}-5 \\
(0.190)\end{array}$ & $\begin{array}{l}1.13 \mathrm{E}-4 \\
(0.217)\end{array}$ & $\begin{array}{c}3.51 \mathrm{E}-3 \\
(6.738)\end{array}$ & $\begin{array}{r}4.03 \mathrm{E}-3 \\
(7.730)\end{array}$ \\
\hline
\end{tabular}

Note: Chemical separation and beta analysis were used to measure ${ }^{90} \mathrm{Sr}$; other nuclides were measured by gamma spectrometry

Note: Values are reported as compact inventory fractions and particle-equivalents (in parentheses)

Note: A less-than value indicates that the concentration in the leachate was below the minimum detectable limit; these values are not included in the totals

Appendix Table A-10. Typically tracked beta/gamma-emitting fission products detected by RDLBL of AGR-3/4 Compact 8-4 Segment 3

\begin{tabular}{|c|c|c|c|c|c|c|c|c|c|}
\hline RDLBL Step & ${ }^{90} \mathrm{Sr}$ & ${ }^{106} \mathrm{Ru}$ & ${ }^{110 m} \mathrm{Ag}$ & ${ }^{125} \mathrm{Sb}$ & ${ }^{134} \mathrm{Cs}$ & ${ }^{137} \mathrm{Cs}$ & ${ }^{144} \mathrm{Ce}$ & ${ }^{154} \mathbf{E u}$ & ${ }^{155} \mathbf{E u}$ \\
\hline Deconsolidation acid & $\begin{array}{l}7.45 \mathrm{E}-4 \\
(1.429)\end{array}$ & $\begin{array}{c}7.63 \mathrm{E}-5 \\
(0.146)\end{array}$ & $\begin{array}{c}<7.0 \mathrm{E}-3 \\
<(13.447)\end{array}$ & $\begin{array}{l}<3.0 \mathrm{E}-5 \\
<(0.058)\end{array}$ & $\begin{array}{c}1.53 \mathrm{E}-5 \\
(0.029)\end{array}$ & $\begin{array}{c}6.06 \mathrm{E}-5 \\
(0.116)\end{array}$ & $\begin{array}{c}3.67 \mathrm{E}-5 \\
(0.070)\end{array}$ & $\begin{array}{c}4.03 \mathrm{E}-4 \\
(0.773)\end{array}$ & $\begin{array}{c}4.54 \mathrm{E}-4 \\
(0.870)\end{array}$ \\
\hline Preburn leach 1 & $\begin{array}{c}2.86 \mathrm{E}-4 \\
(0.549)\end{array}$ & $\begin{array}{c}4.98 \mathrm{E}-5 \\
(0.096)\end{array}$ & $\begin{array}{c}<8.9 \mathrm{E}-3 \\
<(17.162)\end{array}$ & $\begin{array}{c}4.61 \mathrm{E}-5 \\
(0.088)\end{array}$ & $\begin{array}{c}7.76 \mathrm{E}-7 \\
(0.0015)\end{array}$ & $\begin{array}{c}3.48 \mathrm{E}-6 \\
(0.0067)\end{array}$ & $\begin{array}{c}1.03 \mathrm{E}-5 \\
(0.020)\end{array}$ & $\begin{array}{c}8.65 \mathrm{E}-4 \\
(1.659)\end{array}$ & $\begin{array}{c}9.79 \mathrm{E}-4 \\
(1.878)\end{array}$ \\
\hline Preburn leach 2 & $\begin{array}{c}5.00 \mathrm{E}-5 \\
(0.096)\end{array}$ & $\begin{array}{l}<1.7 \mathrm{E}-5 \\
<(0.034)\end{array}$ & $\begin{array}{c}<6.2 \mathrm{E}-3 \\
<(11.852)\end{array}$ & $\begin{array}{c}1.55 \mathrm{E}-5 \\
(0.030)\end{array}$ & $\begin{array}{l}<5.0 \mathrm{E}-7 \\
<(0.001)\end{array}$ & $\begin{array}{c}1.73 \mathrm{E}-6 \\
(0.0033)\end{array}$ & $\begin{array}{l}<7.8 \mathrm{E}-6 \\
<(0.015)\end{array}$ & $\begin{array}{c}2.21 \mathrm{E}-4 \\
(0.424)\end{array}$ & $\begin{array}{c}2.50 \mathrm{E}-6 \\
(0.0048)\end{array}$ \\
\hline Postburn leach 1 & $\begin{array}{c}3.57 \mathrm{E}-3 \\
(6.839)\end{array}$ & $\begin{array}{l}<4.7 \mathrm{E}-5 \\
<(0.090)\end{array}$ & $\begin{array}{c}<1.3 \mathrm{E}-2 \\
<(24.218)\end{array}$ & $\begin{array}{c}6.54 \mathrm{E}-5 \\
(0.126)\end{array}$ & $\begin{array}{c}<1.2 \mathrm{E}-6 \\
<(0.0023)\end{array}$ & $\begin{array}{c}2.00 \mathrm{E}-6 \\
(0.0038)\end{array}$ & $\begin{array}{c}1.27 \mathrm{E}-4 \\
(0.244)\end{array}$ & $\begin{array}{c}4.02 \mathrm{E}-3 \\
(7.714)\end{array}$ & $\begin{array}{c}4.25 \mathrm{E}-3 \\
(8.156)\end{array}$ \\
\hline Postburn leach 2 & $\begin{array}{l}1.86 \mathrm{E}-5 \\
(0.036)\end{array}$ & $\begin{array}{l}<9.6 \mathrm{E}-6 \\
<(0.018)\end{array}$ & $\begin{array}{l}<3.3 \mathrm{E}-3 \\
<(6.380)\end{array}$ & $\begin{array}{l}<6.6 \mathrm{E}-6 \\
<(0.013)\end{array}$ & $\begin{array}{c}1.78 \mathrm{E}-7 \\
(0.0003)\end{array}$ & $\begin{array}{c}9.70 \mathrm{E}-7 \\
(0.0019)\end{array}$ & $\begin{array}{c}4.86 \mathrm{E}-6 \\
(0.0093)\end{array}$ & $\begin{array}{c}2.47 \mathrm{E}-5 \\
(0.047)\end{array}$ & $\begin{array}{c}2.96 \mathrm{E}-5 \\
(0.057)\end{array}$ \\
\hline Total & $\begin{array}{c}4.67 \mathrm{E}-3 \\
(8.948)\end{array}$ & $\begin{array}{c}1.26 \mathrm{E}-4 \\
(0.242)\end{array}$ & $\begin{array}{c}0.00 \mathrm{E}+0 \\
(0.000)\end{array}$ & $\begin{array}{c}1.27 \mathrm{E}-4 \\
(0.244)\end{array}$ & $\begin{array}{c}1.62 \mathrm{E}-5 \\
(0.031)\end{array}$ & $\begin{array}{c}6.88 \mathrm{E}-5 \\
(0.132)\end{array}$ & $\begin{array}{c}1.79 \mathrm{E}-4 \\
(0.344)\end{array}$ & $\begin{array}{l}5.54 \mathrm{E}-3 \\
(10.617)\end{array}$ & $\begin{array}{c}5.72 \mathrm{E}-3 \\
(10.967)\end{array}$ \\
\hline
\end{tabular}

Note: Chemical separation and beta analysis were used to measure ${ }^{90} \mathrm{Sr}$; other nuclides were measured by gamma spectrometry

Note: Values are reported as compact inventory fractions and particle-equivalents (in parentheses)

Note: A less-than value indicates that the concentration in the leachate was below the minimum detectable limit; these values are not included in the totals 
Appendix Table A-11. Typically tracked beta/gamma-emitting fission products detected by RDLBL of AGR-3/4 Compact 8-4 Segment 4

\begin{tabular}{|c|c|c|c|c|c|c|c|c|c|}
\hline RDLBL Step & ${ }^{90} \mathrm{Sr}$ & ${ }^{106} \mathrm{Ru}$ & ${ }^{110 m} \mathrm{Ag}$ & ${ }^{125} \mathrm{Sb}$ & ${ }^{134} \mathrm{Cs}$ & ${ }^{137} \mathrm{Cs}$ & ${ }^{144} \mathrm{Ce}$ & ${ }^{154} \mathbf{E u}$ & ${ }^{155} \mathrm{Eu}$ \\
\hline Deconsolidation acid & $\begin{array}{c}2.08 \mathrm{E}-3 \\
(3.993)\end{array}$ & $\begin{array}{c}4.10 \mathrm{E}-3 \\
(7.867)\end{array}$ & $\begin{array}{c}<1.2 \mathrm{E}-2 \\
<(23.858)\end{array}$ & $\begin{array}{c}3.43 \mathrm{E}-4 \\
(0.657)\end{array}$ & $\begin{array}{c}2.34 \mathrm{E}-4 \\
(0.448)\end{array}$ & $\begin{array}{l}1.05 \mathrm{E}-3 \\
(2.009)\end{array}$ & $\begin{array}{c}3.18 \mathrm{E}-3 \\
(6.097)\end{array}$ & $\begin{array}{l}1.34 \mathrm{E}-3 \\
(2.573)\end{array}$ & $\begin{array}{c}1.95 \mathrm{E}-3 \\
(3.731)\end{array}$ \\
\hline Preburn leach 1 & $\begin{array}{c}3.58 \mathrm{E}-4 \\
(0.686)\end{array}$ & $\begin{array}{l}1.14 \mathrm{E}-3 \\
(2.190)\end{array}$ & $\begin{array}{c}<9.8 \mathrm{E}-3 \\
<(18.797)\end{array}$ & $\begin{array}{c}2.89 \mathrm{E}-4 \\
(0.555)\end{array}$ & $\begin{array}{l}1.90 \mathrm{E}-5 \\
(0.037)\end{array}$ & $\begin{array}{c}7.02 \mathrm{E}-5 \\
(0.135)\end{array}$ & $\begin{array}{c}1.17 \mathrm{E}-3 \\
(2.249)\end{array}$ & $\begin{array}{c}8.98 \mathrm{E}-4 \\
(1.723)\end{array}$ & $\begin{array}{c}9.52 \mathrm{E}-4 \\
(1.825)\end{array}$ \\
\hline Preburn leach 2 & $\begin{array}{c}6.06 \mathrm{E}-5 \\
(0.116)\end{array}$ & $\begin{array}{c}1.38 \mathrm{E}-4 \\
(0.264)\end{array}$ & $\begin{array}{c}<6.1 \mathrm{E}-3 \\
<(11.623)\end{array}$ & $\begin{array}{c}1.10 \mathrm{E}-4 \\
(0.211)\end{array}$ & $\begin{array}{c}5.11 \mathrm{E}-7 \\
(0.001)\end{array}$ & $\begin{array}{c}3.24 \mathrm{E}-6 \\
(0.0062)\end{array}$ & $\begin{array}{c}1.74 \mathrm{E}-4 \\
(0.333)\end{array}$ & $\begin{array}{c}1.43 \mathrm{E}-4 \\
(0.274)\end{array}$ & $\begin{array}{c}1.63 \mathrm{E}-4 \\
(0.313)\end{array}$ \\
\hline Postburn particle leach 1 & $\begin{array}{c}3.94 \mathrm{E}-3 \\
(7.556)\end{array}$ & $\begin{array}{l}1.12 \mathrm{E}-4 \\
(0.215)\end{array}$ & $\begin{array}{c}<1.6 \mathrm{E}-2 \\
<(31.098)\end{array}$ & $\begin{array}{c}5.33 \mathrm{E}-4 \\
(1.022)\end{array}$ & $\begin{array}{c}<1.5 \mathrm{E}-6 \\
<(0.0029)\end{array}$ & $\begin{array}{c}6.23 \mathrm{E}-6 \\
(0.012)\end{array}$ & $\begin{array}{c}4.69 \mathrm{E}-3 \\
(9.003)\end{array}$ & $\begin{array}{c}5.56 \mathrm{E}-3 \\
(10.670)\end{array}$ & $\begin{array}{c}6.02 \mathrm{E}-3 \\
(11.547)\end{array}$ \\
\hline Postburn particle leach 2 & $\begin{array}{c}1.68 \mathrm{E}-5 \\
(0.032)\end{array}$ & $\begin{array}{c}1.17 \mathrm{E}-5 \\
(0.022)\end{array}$ & $\begin{array}{l}<3.9 \mathrm{E}-3 \\
<(7.463)\end{array}$ & $\begin{array}{c}2.59 \mathrm{E}-5 \\
(0.050)\end{array}$ & $\begin{array}{c}<3.9 \mathrm{E}-7 \\
<(0.0007)\end{array}$ & $\begin{array}{l}4.06 \mathrm{E}-7 \\
(0.0008)\end{array}$ & $\begin{array}{c}2.20 \mathrm{E}-5 \\
(0.042)\end{array}$ & $\begin{array}{c}2.62 \mathrm{E}-5 \\
(0.050)\end{array}$ & $\begin{array}{c}2.73 \mathrm{E}-5 \\
(0.052)\end{array}$ \\
\hline Total & $\begin{array}{c}6.46 \mathrm{E}-3 \\
(12.384)\end{array}$ & $\begin{array}{l}5.51 \mathrm{E}-3 \\
(10.559)\end{array}$ & $\begin{array}{c}0.00 \mathrm{E}+0 \\
(0.000)\end{array}$ & $\begin{array}{c}1.30 \mathrm{E}-3 \\
(2.494)\end{array}$ & $\begin{array}{c}2.53 \mathrm{E}-4 \\
(0.486)\end{array}$ & $\begin{array}{c}1.13 \mathrm{E}-3 \\
(2.162)\end{array}$ & $\begin{array}{l}9.24 \mathrm{E}-3 \\
(17.724)\end{array}$ & $\begin{array}{c}7.97 \mathrm{E}-3 \\
(15.290)\end{array}$ & $\begin{array}{c}9.11 \mathrm{E}-3 \\
(17.468)\end{array}$ \\
\hline
\end{tabular}

Note: Chemical separation and beta analysis were used to measure ${ }^{90} \mathrm{Sr}$; other nuclides were measured by gamma spectrometry

Note: Values are reported as compact inventory fractions and particle-equivalents (in parentheses)

Note: A less-than value indicates that the concentration in the leachate was below the minimum detectable limit; these values are not included in the totals 
Appendix Table A-12. Typically tracked beta/gamma-emitting fission products detected by RDLBL of AGR-3/4 Compact 7-4 Segment 1

\begin{tabular}{|c|c|c|c|c|c|c|c|c|c|}
\hline RDLBL Step & ${ }^{90} \mathrm{Sr}$ & ${ }^{106} \mathbf{R u}$ & ${ }^{110 m} \mathrm{Ag}$ & ${ }^{125} \mathrm{Sb}$ & ${ }^{134} \mathrm{Cs}$ & ${ }^{137} \mathrm{Cs}$ & ${ }^{144} \mathrm{Ce}$ & ${ }^{154} \mathbf{E u}$ & ${ }^{155} \mathbf{E u}$ \\
\hline Deconsolidation acid & $\begin{array}{l}1.79 \mathrm{E}-3 \\
(3.437)\end{array}$ & $\begin{array}{c}4.45 \mathrm{E}-4 \\
(0.854)\end{array}$ & $\begin{array}{c}<1.6 \mathrm{E}-2 \\
<(31.018)\end{array}$ & $\begin{array}{c}3.77 \mathrm{E}-4 \\
(0.723)\end{array}$ & $\begin{array}{l}1.92 \mathrm{E}-4 \\
(0.367)\end{array}$ & $\begin{array}{c}2.59 \mathrm{E}-4 \\
(0.498)\end{array}$ & $\begin{array}{c}5.34 \mathrm{E}-4 \\
(1.025)\end{array}$ & $\begin{array}{l}1.64 \mathrm{E}-3 \\
(3.140)\end{array}$ & $\begin{array}{l}1.82 \mathrm{E}-3 \\
(3.484)\end{array}$ \\
\hline Preburn leach 1 & $\begin{array}{c}2.95 \mathrm{E}-4 \\
(0.566)\end{array}$ & $\begin{array}{c}1.52 \mathrm{E}-4 \\
(0.292)\end{array}$ & $\begin{array}{c}<1.8 \mathrm{E}-2 \\
<(33.768)\end{array}$ & $\begin{array}{l}<5.1 \mathrm{E}-5 \\
<(0.098)\end{array}$ & $\begin{array}{c}5.03 \mathrm{E}-5 \\
(0.097)\end{array}$ & $\begin{array}{c}6.24 \mathrm{E}-5 \\
(0.120)\end{array}$ & $\begin{array}{l}<2.9 \mathrm{E}-5 \\
<(0.056)\end{array}$ & $\begin{array}{c}7.07 \mathrm{E}-4 \\
(1.355)\end{array}$ & $\begin{array}{c}8.26 \mathrm{E}-4 \\
(1.584)\end{array}$ \\
\hline Preburn leach 2 & $\begin{array}{c}4.06 \mathrm{E}-5 \\
(0.078)\end{array}$ & $\begin{array}{c}5.73 \mathrm{E}-6 \\
(0.011)\end{array}$ & $\begin{array}{l}<4.6 \mathrm{E}-3 \\
<(8.854)\end{array}$ & $\begin{array}{l}<1.4 \mathrm{E}-5 \\
<(0.026)\end{array}$ & $\begin{array}{l}1.58 \mathrm{E}-5 \\
(0.030)\end{array}$ & $\begin{array}{c}2.15 \mathrm{E}-5 \\
(0.041)\end{array}$ & $\begin{array}{l}<7.1 \mathrm{E}-6 \\
<(0.014)\end{array}$ & $\begin{array}{l}1.07 \mathrm{E}-4 \\
(0.205)\end{array}$ & $\begin{array}{c}1.30 \mathrm{E}-4 \\
(0.250)\end{array}$ \\
\hline Postburn matrix leach 1 & $\begin{array}{c}2.00 \mathrm{E}-3 \\
(3.838)\end{array}$ & $\begin{array}{l}<4.5 \mathrm{E}-5 \\
<(0.086)\end{array}$ & $\begin{array}{c}<1.6 \mathrm{E}-2 \\
<(30.731)\end{array}$ & $\begin{array}{c}8.46 \mathrm{E}-5 \\
(0.162)\end{array}$ & $\begin{array}{c}6.38 \mathrm{E}-5 \\
(0.122)\end{array}$ & $\begin{array}{l}1.45 \mathrm{E}-4 \\
(0.278)\end{array}$ & $\begin{array}{l}<1.8 \mathrm{E}-5 \\
<(0.035)\end{array}$ & $\begin{array}{c}3.09 \mathrm{E}-3 \\
(5.922)\end{array}$ & $\begin{array}{c}3.25 \mathrm{E}-3 \\
(6.242)\end{array}$ \\
\hline Postburn matrix leach 2 & $\begin{array}{c}2.01 \mathrm{E}-5 \\
(0.039)\end{array}$ & $\begin{array}{l}<1.1 \mathrm{E}-5 \\
<(0.022)\end{array}$ & $\begin{array}{l}<2.9 \mathrm{E}-3 \\
<(5.580)\end{array}$ & $\begin{array}{l}1.24 \mathrm{E}-5 \\
(0.024)\end{array}$ & $\begin{array}{c}6.66 \mathrm{E}-6 \\
(0.013)\end{array}$ & $\begin{array}{l}1.65 \mathrm{E}-5 \\
(0.032)\end{array}$ & $\begin{array}{l}<6.5 \mathrm{E}-6 \\
<(0.012)\end{array}$ & $\begin{array}{c}3.69 \mathrm{E}-5 \\
(0.071)\end{array}$ & $\begin{array}{c}3.92 \mathrm{E}-5 \\
(0.075)\end{array}$ \\
\hline Postburn particle leach $1^{a}$ & $\begin{array}{l}1.15 \mathrm{E}-3 \\
(2.211)\end{array}$ & $\begin{array}{c}2.31 \mathrm{E}-5 \\
(0.044)\end{array}$ & $\begin{array}{c}<1.7 \mathrm{E}-2 \\
<(32.622)\end{array}$ & $\begin{array}{l}<2.6 \mathrm{E}-5 \\
<(0.050)\end{array}$ & $\begin{array}{c}7.28 \mathrm{E}-6 \\
(0.014)\end{array}$ & $\begin{array}{c}3.55 \mathrm{E}-5 \\
(0.068)\end{array}$ & $\begin{array}{l}1.35 \mathrm{E}-4 \\
(0.258)\end{array}$ & $\begin{array}{l}1.56 \mathrm{E}-3 \\
(2.992)\end{array}$ & $\begin{array}{l}1.79 \mathrm{E}-3 \\
(3.436)\end{array}$ \\
\hline Postburn particle leach $2^{a}$ & $\begin{array}{l}1.38 \mathrm{E}-5 \\
(0.027)\end{array}$ & $\begin{array}{l}<9.6 \mathrm{E}-6 \\
<(0.018)\end{array}$ & $\begin{array}{l}<2.8 \mathrm{E}-3 \\
<(5.348)\end{array}$ & $\begin{array}{l}<7.1 \mathrm{E}-6 \\
<(0.014)\end{array}$ & $\begin{array}{c}1.05 \mathrm{E}-6 \\
(0.002)\end{array}$ & $\begin{array}{c}4.82 \mathrm{E}-6 \\
(0.0092)\end{array}$ & $\begin{array}{c}7.48 \mathrm{E}-6 \\
(0.014)\end{array}$ & $\begin{array}{l}1.28 \mathrm{E}-5 \\
(0.024)\end{array}$ & $\begin{array}{l}1.21 \mathrm{E}-5 \\
(0.023)\end{array}$ \\
\hline Total & $\begin{array}{c}5.32 \mathrm{E}-3 \\
(10.196)\end{array}$ & $\begin{array}{c}6.21 \mathrm{E}-4 \\
(1.191)\end{array}$ & $\begin{array}{c}0.00 \mathrm{E}+0 \\
(0.000)\end{array}$ & $\begin{array}{c}4.74 \mathrm{E}-4 \\
(0.909)\end{array}$ & $\begin{array}{c}3.36 \mathrm{E}-4 \\
(0.645)\end{array}$ & $\begin{array}{c}5.45 \mathrm{E}-4 \\
(1.046)\end{array}$ & $\begin{array}{c}6.77 \mathrm{E}-4 \\
(1.298)\end{array}$ & $\begin{array}{l}7.15 \mathrm{E}-3 \\
(13.710)\end{array}$ & $\begin{array}{c}7.87 \mathrm{E}-3 \\
(15.095)\end{array}$ \\
\hline
\end{tabular}

Note: Chemical separation and beta analysis were used to measure ${ }^{90} \mathrm{Sr}$; other nuclides were measured by gamma spectrometry

Note: Values are reported as compact inventory fractions and particle-equivalents (in parentheses)

Note: A less-than value indicates that the concentration in the leachate was below the minimum detectable limit; these values are not included in the totals

${ }^{a}$ Postburn particle leach data were scaled to account for $\sim 11 \%$ particle population withheld from postburn analysis 
Appendix Table A-13. Typically tracked beta/gamma-emitting fission products detected by RDLBL of AGR-3/4 Compact 7-4 Segment 2

\begin{tabular}{|c|c|c|c|c|c|c|c|c|c|}
\hline RDLBL Step & ${ }^{90} \mathrm{Sr}$ & ${ }^{106} \mathbf{R u}$ & ${ }^{110 m} \mathrm{Ag}$ & ${ }^{125} \mathrm{Sb}$ & ${ }^{134} \mathrm{Cs}$ & ${ }^{137} \mathrm{Cs}$ & ${ }^{144} \mathrm{Ce}$ & ${ }^{154} \mathbf{E u}$ & ${ }^{155} \mathbf{E u}$ \\
\hline Deconsolidation acid & $\begin{array}{l}1.18 \mathrm{E}-3 \\
(2.270)\end{array}$ & $\begin{array}{l}<6.0 \mathrm{E}-5 \\
<(0.116)\end{array}$ & $\begin{array}{c}<1.8 \mathrm{E}-2 \\
<(34.765)\end{array}$ & $\begin{array}{l}<5.0 \mathrm{E}-5 \\
<(0.096)\end{array}$ & $\begin{array}{c}4.08 \mathrm{E}-5 \\
(0.078)\end{array}$ & $\begin{array}{c}7.25 \mathrm{E}-5 \\
(0.139)\end{array}$ & $\begin{array}{c}4.31 \mathrm{E}-5 \\
(0.083)\end{array}$ & $\begin{array}{l}1.11 \mathrm{E}-3 \\
(2.136)\end{array}$ & $\begin{array}{l}1.20 \mathrm{E}-3 \\
(2.300)\end{array}$ \\
\hline Preburn leach 1 & $\begin{array}{c}3.59 \mathrm{E}-4 \\
(0.689)\end{array}$ & $\begin{array}{l}<2.1 \mathrm{E}-5 \\
<(0.040)\end{array}$ & $\begin{array}{c}<8.5 \mathrm{E}-3 \\
<(16.261)\end{array}$ & $\begin{array}{l}<1.2 \mathrm{E}-5 \\
<(0.024)\end{array}$ & $\begin{array}{c}9.74 \mathrm{E}-7 \\
(0.0019)\end{array}$ & $\begin{array}{c}3.76 \mathrm{E}-6 \\
(0.0072)\end{array}$ & $\begin{array}{l}<9.3 \mathrm{E}-6 \\
<(0.018)\end{array}$ & $\begin{array}{c}6.03 \mathrm{E}-4 \\
(1.157)\end{array}$ & $\begin{array}{c}6.97 \mathrm{E}-4 \\
(1.337)\end{array}$ \\
\hline Preburn leach 2 & $\begin{array}{c}5.00 \mathrm{E}-5 \\
(0.096)\end{array}$ & $\begin{array}{l}<1.1 \mathrm{E}-5 \\
<(0.021)\end{array}$ & $\begin{array}{l}<4.7 \mathrm{E}-3 \\
<(9.021)\end{array}$ & $\begin{array}{l}1.12 \mathrm{E}-5 \\
(0.022)\end{array}$ & $\begin{array}{c}<3.1 \mathrm{E}-7 \\
<(0.0006)\end{array}$ & $\begin{array}{c}7.18 \mathrm{E}-7 \\
(0.0014)\end{array}$ & $\begin{array}{l}<5.0 \mathrm{E}-6 \\
<(0.0097)\end{array}$ & $\begin{array}{c}9.65 \mathrm{E}-5 \\
(0.185)\end{array}$ & $\begin{array}{c}1.10 \mathrm{E}-4 \\
(0.210)\end{array}$ \\
\hline Postburn matrix leach 1 & $\begin{array}{c}2.18 \mathrm{E}-3 \\
(4.177)\end{array}$ & $\begin{array}{l}<4.1 \mathrm{E}-5 \\
<(0.078)\end{array}$ & $\begin{array}{c}<1.6 \mathrm{E}-2 \\
<(29.952)\end{array}$ & $\begin{array}{l}7.33 \mathrm{E}-5 \\
(0.141)\end{array}$ & $\begin{array}{c}4.20 \mathrm{E}-6 \\
(0.0081)\end{array}$ & $\begin{array}{c}1.97 \mathrm{E}-5 \\
(0.038)\end{array}$ & $\begin{array}{c}2.39 \mathrm{E}-5 \\
(0.046)\end{array}$ & $\begin{array}{c}3.25 \mathrm{E}-3 \\
(6.240)\end{array}$ & $\begin{array}{c}3.66 \mathrm{E}-3 \\
(7.027)\end{array}$ \\
\hline Postburn matrix leach 2 & $\begin{array}{c}6.14 \mathrm{E}-5 \\
(0.118)\end{array}$ & $\begin{array}{l}<8.6 \mathrm{E}-6 \\
<(0.017)\end{array}$ & $\begin{array}{l}<3.3 \mathrm{E}-3 \\
<(6.411)\end{array}$ & $\begin{array}{c}9.32 \mathrm{E}-6 \\
(0.018)\end{array}$ & $\begin{array}{c}1.47 \mathrm{E}-6 \\
(0.0028)\end{array}$ & $\begin{array}{c}5.16 \mathrm{E}-6 \\
(0.0099)\end{array}$ & $\begin{array}{c}<4.0 \mathrm{E}-6 \\
<(0.0078)\end{array}$ & $\begin{array}{l}1.05 \mathrm{E}-4 \\
(0.200)\end{array}$ & $\begin{array}{c}1.19 \mathrm{E}-4 \\
(0.229)\end{array}$ \\
\hline Postburn particle leach $1^{a}$ & $\begin{array}{c}7.92 \mathrm{E}-4 \\
(1.519)\end{array}$ & $\begin{array}{l}<4.2 \mathrm{E}-5 \\
<(0.081)\end{array}$ & $\begin{array}{c}<1.4 \mathrm{E}-2 \\
<(27.803)\end{array}$ & $\begin{array}{l}<2.6 \mathrm{E}-5 \\
<(0.050)\end{array}$ & $\begin{array}{c}1.56 \mathrm{E}-6 \\
(0.003)\end{array}$ & $\begin{array}{c}2.46 \mathrm{E}-5 \\
(0.047)\end{array}$ & $\begin{array}{l}7.42 \mathrm{E}-5 \\
(0.142)\end{array}$ & $\begin{array}{l}1.05 \mathrm{E}-3 \\
(2.014)\end{array}$ & $\begin{array}{c}1.10 \mathrm{E}-3 \\
(2.107)\end{array}$ \\
\hline Postburn particle leach $2^{a}$ & $\begin{array}{c}2.06 \mathrm{E}-5 \\
(0.039)\end{array}$ & $\begin{array}{l}<8.0 \mathrm{E}-6 \\
<(0.015)\end{array}$ & $\begin{array}{l}<2.7 \mathrm{E}-3 \\
<(5.250)\end{array}$ & $\begin{array}{l}<5.6 \mathrm{E}-6 \\
<(0.011)\end{array}$ & $\begin{array}{c}2.43 \mathrm{E}-7 \\
(0.0005)\end{array}$ & $\begin{array}{c}3.40 \mathrm{E}-6 \\
(0.0065)\end{array}$ & $\begin{array}{c}3.38 \mathrm{E}-6 \\
(0.0065)\end{array}$ & $\begin{array}{l}1.38 \mathrm{E}-5 \\
(0.026)\end{array}$ & $\begin{array}{c}1.54 \mathrm{E}-5 \\
(0.030)\end{array}$ \\
\hline Total & $\begin{array}{c}4.64 \mathrm{E}-3 \\
(8.909)\end{array}$ & $\begin{array}{c}0.00 \mathrm{E}+0 \\
(0.000)\end{array}$ & $\begin{array}{c}0.00 \mathrm{E}+0 \\
(0.000)\end{array}$ & $\begin{array}{c}9.39 \mathrm{E}-5 \\
(0.180)\end{array}$ & $\begin{array}{c}4.93 \mathrm{E}-5 \\
(0.094)\end{array}$ & $\begin{array}{c}1.30 \mathrm{E}-4 \\
(0.249)\end{array}$ & $\begin{array}{l}1.45 \mathrm{E}-4 \\
(0.277)\end{array}$ & $\begin{array}{c}6.24 \mathrm{E}-3 \\
(11.960)\end{array}$ & $\begin{array}{c}6.90 \mathrm{E}-3 \\
(13.239)\end{array}$ \\
\hline
\end{tabular}

Note: Chemical separation and beta analysis were used to measure ${ }^{90} \mathrm{Sr}$; other nuclides were measured by gamma spectrometry

Note: Values are reported as compact inventory fractions and particle-equivalents (in parentheses)

Note: A less-than value indicates that the concentration in the leachate was below the minimum detectable limit; these values are not included in the totals

${ }^{a}$ Postburn particle leach data were scaled to account for $\sim 11 \%$ particle population withheld from postburn analysis 
Appendix Table A-14. Typically tracked beta/gamma-emitting fission products detected by RDLBL of AGR-3/4 Compact 7-4 Segment 3

\begin{tabular}{lccccccccc}
\hline RDLBL Step & ${ }^{90} \mathbf{S r}$ & ${ }^{106} \mathbf{R u}$ & ${ }^{110 m} \mathbf{m g}$ & ${ }^{125} \mathbf{S b}$ & ${ }^{134} \mathbf{C s}$ & ${ }^{137} \mathbf{C s}$ & ${ }^{144} \mathbf{C e}$ & ${ }^{154} \mathbf{E u}$ & ${ }^{155} \mathbf{E u}$ \\
\hline \multirow{2}{*}{ Deconsolidation acid } & $3.73 \mathrm{E}-3$ & $2.25 \mathrm{E}-3$ & $<5.4 \mathrm{E}-2$ & $6.96 \mathrm{E}-4$ & $8.72-4$ & $2.00 \mathrm{E}-3$ & $2.29 \mathrm{E}-3$ & $1.85 \mathrm{E}-3$ & $2.23 \mathrm{E}-3$ \\
& $(7.16)$ & $(4.314)$ & $<(104.190)$ & $(1.34)$ & $(1.672)$ & $(3.830)$ & $(4.397)$ & $(3.545)$ & $(4.274)$ \\
Preburn leach 1 & $7.53 \mathrm{E}-4$ & $3.83 \mathrm{E}-3$ & $<1.8 \mathrm{E}-2$ & $4.03 \mathrm{E}-4$ & $2.11 \mathrm{E}-4$ & $2.92 \mathrm{E}-4$ & $1.20 \mathrm{E}-3$ & $1.44 \mathrm{E}-3$ & $1.60 \mathrm{E}-3$ \\
& $(1.445)$ & $(7.354)$ & $<(34.007)$ & $(0.772)$ & $(0.404)$ & $(0.561)$ & $(2.304)$ & $(2.757)$ & $(3.064)$ \\
Preburn leach 2 & $9.80 \mathrm{E}-5$ & $1.95 \mathrm{E}-4$ & $<8.2 \mathrm{E}-3$ & $1.03 \mathrm{E}-4$ & $3.90 \mathrm{E}-5$ & $5.22 \mathrm{E}-5$ & $1.88 \mathrm{E}-4$ & $2.17 \mathrm{E}-4$ & $2.52 \mathrm{E}-4$ \\
& $(0.188)$ & $(0.374)$ & $<(15.777)$ & $(0.198)$ & $(0.075)$ & $(0.100)$ & $(0.360)$ & $(0.415)$ & $(0.484)$ \\
Postburn matrix leach 1 & $4.31 \mathrm{E}-3$ & $3.19 \mathrm{E}-4$ & $<3.6 \mathrm{E}-2$ & $1.08 \mathrm{E}-3$ & $6.43 \mathrm{E}-5$ & $9.93 \mathrm{E}-5$ & $1.98 \mathrm{E}-3$ & $6.51 \mathrm{E}-3$ & $6.97 \mathrm{E}-3$ \\
& $(8.260)$ & $(0.611)$ & $<(69.620)$ & $(2.07)$ & $(0.123)$ & $(0.190)$ & $(3.801)$ & $(12.478)$ & $(13.366)$ \\
Postburn matrix leach 2 & $4.46 \mathrm{E}-5$ & $2.63 \mathrm{E}-5$ & $<2.9 \mathrm{E}-3$ & $2.51 \mathrm{E}-5$ & $4.76 \mathrm{E}-6$ & $8.13 \mathrm{E}-6$ & $1.87 \mathrm{E}-5$ & $6.13 \mathrm{E}-5$ & $6.16 \mathrm{E}-05$ \\
& $(0.086)$ & $(0.050)$ & $<(5.582)$ & $(0.0482)$ & $(0.0091)$ & $(0.016)$ & $(0.036)$ & $(0.118)$ & $(0.118)$ \\
Postburn particle leach 1 ${ }^{a}$ & $2.58 \mathrm{E}-3$ & $5.25 \mathrm{E}-5$ & $<2.6 \mathrm{E}-2$ & $1.94 \mathrm{E}-4$ & $4.60 \mathrm{E}-6$ & $1.79 \mathrm{E}-5$ & $3.10 \mathrm{E}-3$ & $3.70 \mathrm{E}-3$ & $4.29 \mathrm{E}-3$ \\
& $(4.958)$ & $(0.101)$ & $<(49.852)$ & $(0.373)$ & $(0.0088)$ & $(0.034)$ & $(5.951)$ & $(7.093)$ & $(8.226)$ \\
Postburn particle leach 2 ${ }^{a}$ & $2.19 \mathrm{E}-5$ & $1.70 \mathrm{E}-5$ & $<3.4 \mathrm{E}-3$ & $1.25 \mathrm{E}-5$ & $8.06 \mathrm{E}-7$ & $5.04 \mathrm{E}-6$ & $1.25 \mathrm{E}-4$ & $2.73 \mathrm{E}-5$ & $2.78 \mathrm{E}-5$ \\
& $(0.042)$ & $(0.033)$ & $<(6.554)$ & $(0.0239)$ & $(0.0015)$ & $(0.0097)$ & $(0.239)$ & $(0.052)$ & $(0.053)$ \\
\hline \multirow{2}{*}{ Total } & $1.10 \mathrm{E}-2$ & $6.69 \mathrm{E}-3$ & $0.00 \mathrm{E}+0$ & $1.31 \mathrm{E}-3$ & $1.19 \mathrm{E}-3$ & $2.29 \mathrm{E}-3$ & $8.91 \mathrm{E}-3$ & $1.36 \mathrm{E}-2$ & $1.52 \mathrm{E}-2$ \\
& $(21.167)$ & $(12.837)$ & $(0.000)$ & $(2.514)$ & $(2.284)$ & $(4.399)$ & $(17.089)$ & $(26.101)$ & $(29.244)$ \\
\hline
\end{tabular}

Note: Chemical separation and beta analysis were used to measure ${ }^{90} \mathrm{Sr}$; other nuclides were measured by gamma spectrometry

Note: Values are reported as compact inventory fractions and particle-equivalents (in parentheses)

Note: A less-than value indicates that the concentration in the leachate was below the minimum detectable limit; these values are not included in the totals

${ }^{a}$ Postburn particle leach data were scaled to account for $\sim 11 \%$ particle population withheld from postburn analysis 
Appendix Table A-15. Exposed inventory of stable nuclides of interest detected by RDLBL of AGR-3/4 Compact 8-4 Segment 1

\begin{tabular}{|c|c|c|c|c|c|c|c|c|c|c|}
\hline RDLBL Step & ${ }^{105} \mathrm{Pd}$ & ${ }^{109} \mathrm{Ag}$ & ${ }^{133} \mathrm{Cs}$ & ${ }^{139} \mathbf{L a}$ & ${ }^{140} \mathrm{Ce}$ & ${ }^{141} \mathrm{Pr}$ & ${ }^{146} \mathrm{Nd}$ & ${ }^{152} \mathrm{Sm}$ & ${ }^{153} \mathbf{E u}$ & ${ }^{156} \mathbf{G d}$ \\
\hline Deconsolidation acid & $\begin{array}{l}<6.0 \mathrm{E}-5 \\
<(0.116)\end{array}$ & $\begin{array}{l}1.42 \mathrm{E}-3 \\
(2.725)\end{array}$ & $\begin{array}{c}3.08 \mathrm{E}-5 \\
(0.059)\end{array}$ & $\begin{array}{c}4.81 \mathrm{E}-5 \\
(0.092)\end{array}$ & $\begin{array}{c}3.71 \mathrm{E}-5 \\
(0.071)\end{array}$ & $\begin{array}{c}2.56 \mathrm{E}-5 \\
(0.049)\end{array}$ & $\begin{array}{c}2.64 \mathrm{E}-5 \\
(0.051)\end{array}$ & $\begin{array}{c}7.59 \mathrm{E}-5 \\
(0.146)\end{array}$ & $\begin{array}{c}6.32 \mathrm{E}-4 \\
(1.213)\end{array}$ & $\begin{array}{c}3.30 \mathrm{E}-4 \\
(0.633)\end{array}$ \\
\hline Preburn leach 1 & $\begin{array}{c}3.09 \mathrm{E}-4 \\
(0.592)\end{array}$ & $\begin{array}{c}5.07 \mathrm{E}-4 \\
(0.972)\end{array}$ & $\begin{array}{c}1.51 \mathrm{E}-5 \\
(0.029)\end{array}$ & $\begin{array}{c}5.89 \mathrm{E}-4 \\
(1.130)\end{array}$ & $\begin{array}{c}3.80 \mathrm{E}-4 \\
(0.729)\end{array}$ & $\begin{array}{c}2.85 \mathrm{E}-5 \\
(0.055)\end{array}$ & $\begin{array}{c}1.04 \mathrm{E}-5 \\
(0.020)\end{array}$ & $\begin{array}{c}3.40 \mathrm{E}-5 \\
(0.065)\end{array}$ & $\begin{array}{c}2.96 \mathrm{E}-4 \\
(0.567)\end{array}$ & $\begin{array}{c}3.50 \mathrm{E}-4 \\
(0.671)\end{array}$ \\
\hline Preburn leach 2 & $\begin{array}{l}<5.5 \mathrm{E}-5 \\
<(0.105)\end{array}$ & $\begin{array}{c}3.96 \mathrm{E}-4 \\
(0.760)\end{array}$ & $\begin{array}{c}4.31 \mathrm{E}-6 \\
(0.0083)\end{array}$ & $\begin{array}{c}2.04 \mathrm{E}-5 \\
(0.039)\end{array}$ & $\begin{array}{c}1.80 \mathrm{E}-4 \\
(0.345)\end{array}$ & $\begin{array}{c}4.28 \mathrm{E}-6 \\
(0.0082)\end{array}$ & $\begin{array}{c}<3.0 \mathrm{E}-6 \\
<(0.0058)\end{array}$ & $\begin{array}{l}<2.1 \mathrm{E}-5 \\
<(0.040)\end{array}$ & $\begin{array}{c}3.32 \mathrm{E}-5 \\
(0.064)\end{array}$ & $\begin{array}{l}<1.2 \mathrm{E}-4 \\
<(0.223)\end{array}$ \\
\hline Postburn particle leach 1 & $\begin{array}{l}1.57 \mathrm{E}-3 \\
(3.010)\end{array}$ & $\begin{array}{c}2.52 \mathrm{E}-4 \\
(0.484)\end{array}$ & $\begin{array}{c}8.35 \mathrm{E}-6 \\
(0.016)\end{array}$ & $\begin{array}{c}4.59 \mathrm{E}-5 \\
(0.088)\end{array}$ & $\begin{array}{c}3.01 \mathrm{E}-4 \\
(0.578)\end{array}$ & $\begin{array}{c}8.89 \mathrm{E}-5 \\
(0.171)\end{array}$ & $\begin{array}{c}7.38 \mathrm{E}-5 \\
(0.141)\end{array}$ & $\begin{array}{c}1.89 \mathrm{E}-4 \\
(0.363)\end{array}$ & $\begin{array}{c}2.04 \mathrm{E}-3 \\
(3.910)\end{array}$ & $\begin{array}{l}1.16 \mathrm{E}-3 \\
(2.231)\end{array}$ \\
\hline Postburn particle leach 2 & $\begin{array}{l}1.58 \mathrm{E}-4 \\
(0.303)\end{array}$ & $\begin{array}{c}3.05 \mathrm{E}-4 \\
(0.585)\end{array}$ & $\begin{array}{c}5.87 \mathrm{E}-6 \\
(0.011)\end{array}$ & $\begin{array}{c}3.02 \mathrm{E}-6 \\
(0.0058)\end{array}$ & $\begin{array}{c}6.99 \mathrm{E}-5 \\
(0.134)\end{array}$ & $\begin{array}{c}5.54 \mathrm{E}-6 \\
(0.011)\end{array}$ & $\begin{array}{l}4.85 \mathrm{E}-6 \\
(0.0093)\end{array}$ & $\begin{array}{l}<2.1 \mathrm{E}-5 \\
<(0.041)\end{array}$ & $\begin{array}{l}<2.6 \mathrm{E}-5 \\
<(0.049)\end{array}$ & $\begin{array}{l}<5.6 \mathrm{E}-5 \\
<(0.108)\end{array}$ \\
\hline Total & $\begin{array}{c}2.04 \mathrm{E}-3 \\
(3.904)\end{array}$ & $\begin{array}{c}2.88 \mathrm{E}-3 \\
(5.526)\end{array}$ & $\begin{array}{c}6.44 \mathrm{E}-5 \\
(0.124)\end{array}$ & $\begin{array}{l}7.07 \mathrm{E}-4 \\
(1.355)\end{array}$ & $\begin{array}{c}9.68 \mathrm{E}-4 \\
(1.857)\end{array}$ & $\begin{array}{c}1.53 \mathrm{E}-4 \\
(0.293)\end{array}$ & $\begin{array}{l}1.15 \mathrm{E}-4 \\
(0.221)\end{array}$ & $\begin{array}{c}2.99 \mathrm{E}-4 \\
(0.574)\end{array}$ & $\begin{array}{c}3.00 \mathrm{E}-3 \\
(5.754)\end{array}$ & $\begin{array}{c}1.84 \mathrm{E}-3 \\
(3.535)\end{array}$ \\
\hline
\end{tabular}

Note: Values are reported as compact inventory fractions and particle-equivalents (in parentheses)

Note: A less-than value indicates that the concentration in the leachate was below the minimum detectable limit; these values are not included in the totals

Appendix Table A-16. Exposed inventory of stable nuclides of interest detected by RDLBL of AGR-3/4 Compact 8-4 Segment 2

\begin{tabular}{|c|c|c|c|c|c|c|c|c|c|c|}
\hline RDLBL Step & ${ }^{105} \mathrm{Pd}$ & ${ }^{109} \mathrm{Ag}$ & ${ }^{133} \mathrm{Cs}$ & ${ }^{139} \mathrm{La}$ & ${ }^{140} \mathrm{Ce}$ & ${ }^{141} \mathrm{Pr}$ & ${ }^{146} \mathrm{Nd}$ & ${ }^{152} \mathrm{Sm}$ & ${ }^{153} \mathbf{E u}$ & ${ }^{156} \mathrm{Gd}$ \\
\hline Deconsolidation acid & $\begin{array}{l}<4.1 \mathrm{E}-5 \\
<(0.079)\end{array}$ & $\begin{array}{l}1.14 \mathrm{E}-3 \\
(2.186)\end{array}$ & $\begin{array}{c}8.38 \mathrm{E}-5 \\
(0.161)\end{array}$ & $\begin{array}{c}5.81 \mathrm{E}-5 \\
(0.111)\end{array}$ & $\begin{array}{c}4.83 \mathrm{E}-5 \\
(0.093)\end{array}$ & $\begin{array}{c}4.37 \mathrm{E}-5 \\
(0.084)\end{array}$ & $\begin{array}{c}4.38 \mathrm{E}-5 \\
(0.084)\end{array}$ & $\begin{array}{c}9.59 \mathrm{E}-5 \\
(0.184)\end{array}$ & $\begin{array}{c}6.38 \mathrm{E}-4 \\
(1.224)\end{array}$ & $\begin{array}{c}3.92 \mathrm{E}-4 \\
(0.752)\end{array}$ \\
\hline Preburn leach 1 & $\begin{array}{c}2.14 \mathrm{E}-4 \\
(0.411)\end{array}$ & $\begin{array}{c}3.56 \mathrm{E}-3 \\
(6.834)\end{array}$ & $\begin{array}{l}1.31 \mathrm{E}-5 \\
(0.025)\end{array}$ & $\begin{array}{c}2.71 \mathrm{E}-5 \\
(0.052)\end{array}$ & $\begin{array}{c}7.64 \mathrm{E}-5 \\
(0.147)\end{array}$ & $\begin{array}{c}9.40 \mathrm{E}-6 \\
(0.018)\end{array}$ & $\begin{array}{c}8.37 \mathrm{E}-6 \\
(0.016)\end{array}$ & $\begin{array}{c}3.18 \mathrm{E}-5 \\
(0.061)\end{array}$ & $\begin{array}{c}3.57 \mathrm{E}-4 \\
(0.686)\end{array}$ & $\begin{array}{c}1.84 \mathrm{E}-4 \\
(0.352)\end{array}$ \\
\hline Preburn leach 2 & $\begin{array}{l}<5.8 \mathrm{E}-5 \\
<(0.112)\end{array}$ & $\begin{array}{c}3.30 \mathrm{E}-3 \\
(6.326)\end{array}$ & $\begin{array}{c}6.62 \mathrm{E}-6 \\
(0.013)\end{array}$ & $\begin{array}{c}8.30 \mathrm{E}-6 \\
(0.016)\end{array}$ & $\begin{array}{c}6.46 \mathrm{E}-5 \\
(0.124)\end{array}$ & $\begin{array}{c}4.08 \mathrm{E}-6 \\
(0.0078)\end{array}$ & $\begin{array}{c}3.82 \mathrm{E}-6 \\
(0.0073)\end{array}$ & $\begin{array}{l}<2.2 \mathrm{E}-5 \\
<(0.042)\end{array}$ & $\begin{array}{c}6.01 \mathrm{E}-5 \\
(0.115)\end{array}$ & $\begin{array}{c}6.59 \mathrm{E}-5 \\
(0.126)\end{array}$ \\
\hline Postburn particle leach $1^{a}$ & $\begin{array}{c}2.86 \mathrm{E}-4 \\
(0.549)\end{array}$ & $\begin{array}{l}1.59 \mathrm{E}-4 \\
(0.304)\end{array}$ & $\begin{array}{c}6.78 \mathrm{E}-6 \\
(0.013)\end{array}$ & $\begin{array}{c}3.28 \mathrm{E}-5 \\
(0.063)\end{array}$ & $\begin{array}{c}1.59 \mathrm{E}-4 \\
(0.304)\end{array}$ & $\begin{array}{c}6.02 \mathrm{E}-5 \\
(0.115)\end{array}$ & $\begin{array}{c}5.26 \mathrm{E}-5 \\
(0.101)\end{array}$ & $\begin{array}{c}1.65 \mathrm{E}-4 \\
(0.316)\end{array}$ & $\begin{array}{c}2.09 \mathrm{E}-3 \\
(4.015)\end{array}$ & $\begin{array}{c}9.96 \mathrm{E}-4 \\
(1.911)\end{array}$ \\
\hline Postburn particle leach $2^{a}$ & $\begin{array}{l}<6.5 \mathrm{E}-5 \\
<(0.125)\end{array}$ & $\begin{array}{c}1.90 \mathrm{E}-4 \\
(0.365)\end{array}$ & $\begin{array}{c}6.97 \mathrm{E}-6 \\
(0.013)\end{array}$ & $\begin{array}{c}4.51 \mathrm{E}-6 \\
(0.0087)\end{array}$ & $\begin{array}{c}4.13 \mathrm{E}-5 \\
(0.079)\end{array}$ & $\begin{array}{c}6.95 \mathrm{E}-6 \\
(0.013)\end{array}$ & $\begin{array}{c}7.25 \mathrm{E}-6 \\
(0.014)\end{array}$ & $\begin{array}{l}<2.4 \mathrm{E}-5 \\
<(0.047)\end{array}$ & $\begin{array}{l}<3.0 \mathrm{E}-5 \\
<(0.057)\end{array}$ & $\begin{array}{l}<6.5 \mathrm{E}-5 \\
<(0.125)\end{array}$ \\
\hline Total & $\begin{array}{c}5.00 \mathrm{E}-4 \\
(0.960)\end{array}$ & $\begin{array}{c}8.35 \mathrm{E}-3 \\
(16.015)\end{array}$ & $\begin{array}{l}1.17 \mathrm{E}-4 \\
(0.225)\end{array}$ & $\begin{array}{c}1.31 \mathrm{E}-4 \\
(0.251)\end{array}$ & $\begin{array}{c}3.89 \mathrm{E}-4 \\
(0.747)\end{array}$ & $\begin{array}{c}1.24 \mathrm{E}-4 \\
(0.238)\end{array}$ & $\begin{array}{c}1.16 \mathrm{E}-4 \\
(0.222)\end{array}$ & $\begin{array}{c}2.92 \mathrm{E}-4 \\
(0.560)\end{array}$ & $\begin{array}{c}3.15 \mathrm{E}-3 \\
(6.040)\end{array}$ & $\begin{array}{c}1.64 \mathrm{E}-3 \\
(3.142)\end{array}$ \\
\hline
\end{tabular}

Note: Values are reported as compact inventory fractions and particle-equivalents (in parentheses)

Note: A less-than value indicates that the concentration in the leachate was below the minimum detectable limit; these values are not included in the totals 
Appendix Table A-17. Exposed inventory of stable nuclides of interest detected by RDLBL of AGR-3/4 Compact 8-4 Segment 3

\begin{tabular}{|c|c|c|c|c|c|c|c|c|c|c|}
\hline RDLBL Step & ${ }^{105} \mathrm{Pd}$ & ${ }^{109} \mathrm{Ag}$ & ${ }^{133} \mathrm{Cs}$ & ${ }^{139} \mathrm{La}$ & ${ }^{140} \mathrm{Ce}$ & ${ }^{141} \mathrm{Pr}$ & $146 \mathrm{Nd}$ & ${ }^{152} \mathrm{Sm}$ & ${ }^{153} \mathbf{E u}$ & ${ }^{156}$ Gd \\
\hline Deconsolidation acid & $\begin{array}{l}<4.0 \mathrm{E}-5 \\
<(0.077)\end{array}$ & $\begin{array}{c}6.34 \mathrm{E}-4 \\
(1.215)\end{array}$ & $\begin{array}{c}1.00 \mathrm{E}-4 \\
(0.192)\end{array}$ & $\begin{array}{c}6.32 \mathrm{E}-5 \\
(0.121)\end{array}$ & $\begin{array}{c}5.67 \mathrm{E}-5 \\
(0.109)\end{array}$ & $\begin{array}{c}4.59 \mathrm{E}-5 \\
(0.088)\end{array}$ & $\begin{array}{c}4.80 \mathrm{E}-5 \\
(0.092)\end{array}$ & $\begin{array}{c}1.11 \mathrm{E}-4 \\
(0.213)\end{array}$ & $\begin{array}{c}6.74 \mathrm{E}-4 \\
(1.293)\end{array}$ & $\begin{array}{r}4.35 \mathrm{E}-4 \\
(0.835)\end{array}$ \\
\hline Preburn leach 1 & $\begin{array}{l}<6.1 \mathrm{E}-5 \\
<(0.118)\end{array}$ & $\begin{array}{l}1.33 \mathrm{E}-3 \\
(2.544)\end{array}$ & $\begin{array}{c}9.57 \mathrm{E}-6 \\
(0.018)\end{array}$ & $\begin{array}{c}3.16 \mathrm{E}-5 \\
(0.061)\end{array}$ & $\begin{array}{c}6.52 \mathrm{E}-5 \\
(0.125)\end{array}$ & $\begin{array}{c}9.63 \mathrm{E}-6 \\
(0.018)\end{array}$ & $\begin{array}{c}7.93 \mathrm{E}-6 \\
(0.015)\end{array}$ & $\begin{array}{c}4.21 \mathrm{E}-5 \\
(0.081)\end{array}$ & $\begin{array}{c}4.26 \mathrm{E}-4 \\
(0.818)\end{array}$ & $\begin{array}{c}2.23 \mathrm{E}-4 \\
(0.428)\end{array}$ \\
\hline Preburn leach 2 & $\begin{array}{l}<5.4 \mathrm{E}-5 \\
<(0.103)\end{array}$ & $\begin{array}{c}1.46 \mathrm{E}-4 \\
(0.280)\end{array}$ & $\begin{array}{c}4.24 \mathrm{E}-6 \\
(0.0081)\end{array}$ & $\begin{array}{c}8.89 \mathrm{E}-6 \\
(0.017)\end{array}$ & $\begin{array}{c}4.85 \mathrm{E}-5 \\
(0.093)\end{array}$ & $\begin{array}{c}4.34 \mathrm{E}-6 \\
(0.0083)\end{array}$ & $\begin{array}{l}4.01 \mathrm{E}-6 \\
(0.0077)\end{array}$ & $\begin{array}{l}<2.0 \mathrm{E}-5 \\
<(0.039)\end{array}$ & $\begin{array}{c}5.90 \mathrm{E}-5 \\
(0.113)\end{array}$ & $\begin{array}{c}6.52 \mathrm{E}-5 \\
(0.125)\end{array}$ \\
\hline Postburn particle leach 1 & $\begin{array}{c}2.01 \mathrm{E}-3 \\
(3.858)\end{array}$ & $\begin{array}{c}8.52 \mathrm{E}-3 \\
(16.343)\end{array}$ & $\begin{array}{c}6.13 \mathrm{E}-6 \\
(0.012)\end{array}$ & $\begin{array}{c}5.88 \mathrm{E}-5 \\
(0.113)\end{array}$ & $\begin{array}{c}3.51 \mathrm{E}-4 \\
(0.672)\end{array}$ & $\begin{array}{c}1.40 \mathrm{E}-4 \\
(0.269)\end{array}$ & $\begin{array}{c}9.45 \mathrm{E}-5 \\
(0.181)\end{array}$ & $\begin{array}{c}4.43 \mathrm{E}-4 \\
(0.851)\end{array}$ & $\begin{array}{c}4.23 \mathrm{E}-3 \\
(8.110)\end{array}$ & $\begin{array}{c}2.15 \mathrm{E}-3 \\
(4.122)\end{array}$ \\
\hline Postburn particle leach 2 & $\begin{array}{c}9.58 \mathrm{E}-5 \\
(0.184)\end{array}$ & $\begin{array}{l}1.75 \mathrm{E}-3 \\
(3.361)\end{array}$ & $\begin{array}{c}4.30 \mathrm{E}-6 \\
(0.0082)\end{array}$ & $\begin{array}{c}<1.8 \mathrm{E}-6 \\
<(0.0035)\end{array}$ & $\begin{array}{c}4.43 \mathrm{E}-5 \\
(0.085)\end{array}$ & $\begin{array}{c}3.28 \mathrm{E}-6 \\
(0.0063)\end{array}$ & $\begin{array}{c}<2.9 \mathrm{E}-6 \\
<(0.0057)\end{array}$ & $\begin{array}{l}<2.0 \mathrm{E}-5 \\
<(0.039)\end{array}$ & $\begin{array}{c}2.84 \mathrm{E}-5 \\
(0.054)\end{array}$ & $\begin{array}{l}<5.3 \mathrm{E}-5 \\
<(0.102)\end{array}$ \\
\hline Total & $\begin{array}{c}2.11 \mathrm{E}-3 \\
(4.042)\end{array}$ & $\begin{array}{c}1.24 \mathrm{E}-2 \\
(23.744)\end{array}$ & $\begin{array}{c}1.24 \mathrm{E}-4 \\
(0.238)\end{array}$ & $\begin{array}{c}1.62 \mathrm{E}-4 \\
(0.312)\end{array}$ & $\begin{array}{c}5.65 \mathrm{E}-4 \\
(1.084)\end{array}$ & $\begin{array}{c}2.03 \mathrm{E}-4 \\
(0.390)\end{array}$ & $\begin{array}{c}1.54 \mathrm{E}-4 \\
(0.296)\end{array}$ & $\begin{array}{c}5.96 \mathrm{E}-4 \\
(1.144)\end{array}$ & $\begin{array}{c}5.42 \mathrm{E}-3 \\
(10.389)\end{array}$ & $\begin{array}{c}2.87 \mathrm{E}-3 \\
(5.510)\end{array}$ \\
\hline
\end{tabular}

Note: Values are reported as compact inventory fractions and particle-equivalents (in parentheses)

Note: A less-than value indicates that the concentration in the leachate was below the minimum detectable limit; these values are not included in the totals 
Appendix Table A-18. Exposed inventory of stable nuclides of interest detected by RDLBL of AGR-3/4 Compact 8-4 Segment 4

\begin{tabular}{|c|c|c|c|c|c|c|c|c|c|c|}
\hline RDLBL Step & ${ }^{105} \mathrm{Pd}$ & ${ }^{109} \mathrm{Ag}$ & ${ }^{133} \mathrm{Cs}$ & ${ }^{139} \mathbf{L a}$ & ${ }^{140} \mathrm{Ce}$ & ${ }^{141} \mathrm{Pr}$ & ${ }^{146} \mathrm{Nd}$ & ${ }^{152} \mathrm{Sm}$ & ${ }^{153} \mathbf{E u}$ & ${ }^{156} \mathbf{G d}$ \\
\hline Deconsolidation acid & $\begin{array}{c}5.38 \mathrm{E}-5 \\
(0.103)\end{array}$ & $\begin{array}{c}6.41 \mathrm{E}-3 \\
(12.297)\end{array}$ & $\begin{array}{c}1.01 \mathrm{E}-3 \\
(1.936)\end{array}$ & $\begin{array}{c}2.46 \mathrm{E}-3 \\
(4.711)\end{array}$ & $\begin{array}{c}2.49 \mathrm{E}-3 \\
(4.770)\end{array}$ & $\begin{array}{c}2.65 \mathrm{E}-3 \\
(5.087)\end{array}$ & $\begin{array}{c}2.36 \mathrm{E}-3 \\
(4.521)\end{array}$ & $\begin{array}{c}2.31 \mathrm{E}-3 \\
(4.432)\end{array}$ & $\begin{array}{c}1.78 \mathrm{E}-3 \\
(3.424)\end{array}$ & $\begin{array}{c}3.22 \mathrm{E}-3 \\
(6.175)\end{array}$ \\
\hline Preburn leach 1 & $\begin{array}{c}2.09 \mathrm{E}-4 \\
(0.400)\end{array}$ & $\begin{array}{c}5.00 \mathrm{E}-3 \\
(9.586)\end{array}$ & $\begin{array}{c}8.64 \mathrm{E}-5 \\
(0.166)\end{array}$ & $\begin{array}{c}1.27 \mathrm{E}-3 \\
(2.442)\end{array}$ & $\begin{array}{c}1.28 \mathrm{E}-3 \\
(2.458)\end{array}$ & $\begin{array}{c}1.19 \mathrm{E}-3 \\
(2.286)\end{array}$ & $\begin{array}{c}9.56 \mathrm{E}-4 \\
(1.834)\end{array}$ & $\begin{array}{c}8.41 \mathrm{E}-4 \\
(1.612)\end{array}$ & $\begin{array}{c}9.83 \mathrm{E}-4 \\
(1.886)\end{array}$ & $\begin{array}{c}1.56 \mathrm{E}-3 \\
(2.996)\end{array}$ \\
\hline Preburn leach 2 & $\begin{array}{l}<6.2 \mathrm{E}-5 \\
<(0.119)\end{array}$ & $\begin{array}{c}1.72 \mathrm{E}-4 \\
(0.329)\end{array}$ & $\begin{array}{c}8.04 \mathrm{E}-6 \\
(0.015)\end{array}$ & $\begin{array}{c}1.66 \mathrm{E}-4 \\
(0.319)\end{array}$ & $\begin{array}{c}2.00 \mathrm{E}-4 \\
(0.384)\end{array}$ & $\begin{array}{c}1.62 \mathrm{E}-4 \\
(0.311)\end{array}$ & $\begin{array}{c}1.24 \mathrm{E}-4 \\
(0.238)\end{array}$ & $\begin{array}{c}8.30 \mathrm{E}-5 \\
(0.159)\end{array}$ & $\begin{array}{c}1.02 \mathrm{E}-4 \\
(0.196)\end{array}$ & $\begin{array}{c}2.16 \mathrm{E}-4 \\
(0.414)\end{array}$ \\
\hline Postburn particle leach 1 & $\begin{array}{l}1.78 \mathrm{E}-3 \\
(3.414)\end{array}$ & $\begin{array}{c}4.62 \mathrm{E}-4 \\
(0.885)\end{array}$ & $\begin{array}{c}1.31 \mathrm{E}-5 \\
(0.025)\end{array}$ & $\begin{array}{c}2.59 \mathrm{E}-3 \\
(4.966)\end{array}$ & $\begin{array}{c}5.32 \mathrm{E}-3 \\
(10.202)\end{array}$ & $\begin{array}{c}5.05 \mathrm{E}-3 \\
(9.695)\end{array}$ & $\begin{array}{c}4.16 \mathrm{E}-3 \\
(7.982)\end{array}$ & $\begin{array}{c}4.87 \mathrm{E}-3 \\
(9.346)\end{array}$ & $\begin{array}{c}6.56 \mathrm{E}-3 \\
(12.576)\end{array}$ & $\begin{array}{l}8.07 \mathrm{E}-3 \\
(15.476)\end{array}$ \\
\hline Postburn particle leach 2 & $\begin{array}{l}1.46 \mathrm{E}-4 \\
(0.279)\end{array}$ & $\begin{array}{l}<6.2 \mathrm{E}-5 \\
<(0.118)\end{array}$ & $\begin{array}{c}3.02 \mathrm{E}-6 \\
(0.0058)\end{array}$ & $\begin{array}{c}1.08 \mathrm{E}-5 \\
(0.021)\end{array}$ & $\begin{array}{c}5.41 \mathrm{E}-5 \\
(0.104)\end{array}$ & $\begin{array}{c}2.16 \mathrm{E}-5 \\
(0.042)\end{array}$ & $\begin{array}{c}1.73 E-5 \\
(0.033)\end{array}$ & $\begin{array}{c}2.29 \mathrm{E}-5 \\
(0.044)\end{array}$ & $\begin{array}{c}3.30 \mathrm{E}-5 \\
(0.063)\end{array}$ & $\begin{array}{l}<5.6 \mathrm{E}-5 \\
<(0.108)\end{array}$ \\
\hline Total & $\begin{array}{c}2.19 \mathrm{E}-3 \\
(4.197)\end{array}$ & $\begin{array}{l}1.20 \mathrm{E}-2 \\
(23.097)\end{array}$ & $\begin{array}{c}1.12 \mathrm{E}-3 \\
(2.148)\end{array}$ & $\begin{array}{c}6.50 \mathrm{E}-3 \\
(12.459)\end{array}$ & $\begin{array}{c}9.34 \mathrm{E}-3 \\
(17.918)\end{array}$ & $\begin{array}{c}9.08 \mathrm{E}-3 \\
(17.420)\end{array}$ & $\begin{array}{c}7.62 \mathrm{E}-3 \\
(14.608)\end{array}$ & $\begin{array}{c}8.13 \mathrm{E}-3 \\
(15.593)\end{array}$ & $\begin{array}{c}9.46 \mathrm{E}-3 \\
(18.146)\end{array}$ & $\begin{array}{l}1.31 \mathrm{E}-2 \\
(25.061)\end{array}$ \\
\hline
\end{tabular}

Note: Values are reported as compact inventory fractions and particle-equivalents (in parentheses)

Note: A less-than value indicates that the concentration in the leachate was below the minimum detectable limit; these values are not included in the totals 
Appendix Table A-19. Exposed inventory of stable nuclides of interest detected by RDLBL of AGR-3/4 Compact 7-4 Segment 1

\begin{tabular}{|c|c|c|c|c|c|c|c|c|c|c|}
\hline RDLBL Step & ${ }^{105} \mathrm{Pd}$ & ${ }^{109} \mathrm{Ag}$ & ${ }^{133} \mathrm{Cs}$ & ${ }^{139} \mathbf{L a}$ & ${ }^{140} \mathrm{Ce}$ & ${ }^{141} \mathrm{Pr}$ & $146 \mathrm{Nd}$ & ${ }^{152} \mathrm{Sm}$ & ${ }^{153} \mathbf{E u}$ & ${ }^{156}$ Gd \\
\hline Deconsolidation acid & $\begin{array}{c}8.28 \mathrm{E}-5 \\
(0.159)\end{array}$ & $\begin{array}{l}1.18 \mathrm{E}-3 \\
(2.266)\end{array}$ & $\begin{array}{c}2.41 \mathrm{E}-4 \\
(0.462)\end{array}$ & $\begin{array}{c}5.96 \mathrm{E}-4 \\
(1.143)\end{array}$ & $\begin{array}{c}5.34 \mathrm{E}-4 \\
(1.023)\end{array}$ & $\begin{array}{c}5.50 \mathrm{E}-4 \\
(1.055)\end{array}$ & $\begin{array}{c}4.65 \mathrm{E}-4 \\
(0.892)\end{array}$ & $\begin{array}{c}6.06 \mathrm{E}-4 \\
(1.163)\end{array}$ & $\begin{array}{c}1.67 \mathrm{E}-3 \\
(3.207)\end{array}$ & $\begin{array}{r}1.46 \mathrm{E}-3 \\
(2.794)\end{array}$ \\
\hline Preburn leach 1 & $\begin{array}{c}5.01 \mathrm{E}-4 \\
(0.960)\end{array}$ & $\begin{array}{c}1.99 \mathrm{E}-4 \\
(0.381)\end{array}$ & $\begin{array}{c}6.37 \mathrm{E}-5 \\
(0.122)\end{array}$ & $\begin{array}{c}3.47 \mathrm{E}-5 \\
(0.066)\end{array}$ & $\begin{array}{c}9.61 \mathrm{E}-5 \\
(0.184)\end{array}$ & $\begin{array}{c}1.09 \mathrm{E}-5 \\
(0.021)\end{array}$ & $\begin{array}{c}8.42 \mathrm{E}-6 \\
(0.016)\end{array}$ & $\begin{array}{c}3.49 \mathrm{E}-5 \\
(0.067)\end{array}$ & $\begin{array}{c}6.19 \mathrm{E}-4 \\
(1.187)\end{array}$ & $\begin{array}{c}3.02 \mathrm{E}-4 \\
(0.579)\end{array}$ \\
\hline Preburn leach 2 & $\begin{array}{c}7.96 \mathrm{E}-5 \\
(0.153)\end{array}$ & $\begin{array}{c}1.05 \mathrm{E}-4 \\
(0.202)\end{array}$ & $\begin{array}{c}2.16 \mathrm{E}-5 \\
(0.041)\end{array}$ & $\begin{array}{c}8.61 \mathrm{E}-6 \\
(0.017)\end{array}$ & $\begin{array}{c}6.86 \mathrm{E}-5 \\
(0.132)\end{array}$ & $\begin{array}{c}3.53 \mathrm{E}-6 \\
(0.0068)\end{array}$ & $\begin{array}{l}<2.8 \mathrm{E}-6 \\
<(0.0054)\end{array}$ & $\begin{array}{l}<2.0 \mathrm{E}-5 \\
<(0.038)\end{array}$ & $\begin{array}{c}7.40 \mathrm{E}-5 \\
(0.142)\end{array}$ & $\begin{array}{r}6.45 \mathrm{E}-5 \\
(0.124)\end{array}$ \\
\hline Postburn matrix leach 1 & $\begin{array}{l}7.42 \mathrm{E}-4 \\
(1.423)\end{array}$ & $\begin{array}{c}6.90 \mathrm{E}-4 \\
(1.324)\end{array}$ & $\begin{array}{c}1.34 \mathrm{E}-4 \\
(0.256)\end{array}$ & $\begin{array}{l}1.75 \mathrm{E}-4 \\
(0.335)\end{array}$ & $\begin{array}{c}3.37 \mathrm{E}-4 \\
(0.646)\end{array}$ & $\begin{array}{c}8.94 \mathrm{E}-5 \\
(0.171)\end{array}$ & $\begin{array}{c}8.29 \mathrm{E}-5 \\
(0.159)\end{array}$ & $\begin{array}{c}2.17 \mathrm{E}-4 \\
(0.417)\end{array}$ & $\begin{array}{c}3.24 \mathrm{E}-3 \\
(6.219)\end{array}$ & $\begin{array}{c}1.61 \mathrm{E}-3 \\
(3.089)\end{array}$ \\
\hline Postburn matrix leach 2 & $\begin{array}{l}<2.8 \mathrm{E}-5 \\
<(0.053)\end{array}$ & $\begin{array}{c}6.39 \mathrm{E}-5 \\
(0.123)\end{array}$ & $\begin{array}{l}1.33 \mathrm{E}-5 \\
(0.026)\end{array}$ & $\begin{array}{c}3.64 \mathrm{E}-6 \\
(0.007)\end{array}$ & $\begin{array}{l}1.52 \mathrm{E}-5 \\
(0.029)\end{array}$ & $\begin{array}{c}1.87 \mathrm{E}-6 \\
(0.0036)\end{array}$ & $\begin{array}{c}1.79 \mathrm{E}-6 \\
(0.0034)\end{array}$ & $\begin{array}{l}<1.1 \mathrm{E}-5 \\
<(0.020)\end{array}$ & $\begin{array}{c}3.49 \mathrm{E}-5 \\
(0.067)\end{array}$ & $\begin{array}{l}<2.6 \mathrm{E}-5 \\
<(0.050)\end{array}$ \\
\hline Postburn particle leach $1^{a}$ & $\begin{array}{c}5.06 \mathrm{E}-4 \\
(0.970)\end{array}$ & $\begin{array}{c}2.07 \mathrm{E}-4 \\
(0.398)\end{array}$ & $\begin{array}{c}3.93 \mathrm{E}-5 \\
(0.075)\end{array}$ & $\begin{array}{c}1.61 \mathrm{E}-4 \\
(0.308)\end{array}$ & $\begin{array}{c}5.27 \mathrm{E}-4 \\
(1.011)\end{array}$ & $\begin{array}{c}3.10 \mathrm{E}-4 \\
(0.595)\end{array}$ & $\begin{array}{c}2.57 \mathrm{E}-4 \\
(0.493)\end{array}$ & $\begin{array}{c}2.58 \mathrm{E}-4 \\
(0.495)\end{array}$ & $\begin{array}{c}1.84 \mathrm{E}-3 \\
(3.531)\end{array}$ & $\begin{array}{c}2.14 \mathrm{E}-3 \\
(4.112)\end{array}$ \\
\hline Postburn particle leach $2^{a}$ & $\begin{array}{c}6.19 \mathrm{E}-5 \\
(0.119)\end{array}$ & $\begin{array}{c}1.89 \mathrm{E}-4 \\
(0.363)\end{array}$ & $\begin{array}{c}6.11 \mathrm{E}-6 \\
(0.012)\end{array}$ & $\begin{array}{c}4.70 \mathrm{E}-6 \\
(0.009)\end{array}$ & $\begin{array}{c}5.15 \mathrm{E}-5 \\
(0.099)\end{array}$ & $\begin{array}{c}8.20 \mathrm{E}-6 \\
(0.016)\end{array}$ & $\begin{array}{l}7.52 \mathrm{E}-6 \\
(0.014)\end{array}$ & $\begin{array}{l}<2.0 \mathrm{E}-5 \\
<(0.038)\end{array}$ & $\begin{array}{l}<2.4 \mathrm{E}-5 \\
<(0.045)\end{array}$ & $\begin{array}{l}<4.9 \mathrm{E}-5 \\
<(0.095)\end{array}$ \\
\hline Total & $\begin{array}{l}1.97 \mathrm{E}-3 \\
(3.783)\end{array}$ & $\begin{array}{c}2.64 \mathrm{E}-3 \\
(5.058)\end{array}$ & $\begin{array}{c}5.18 \mathrm{E}-4 \\
(0.994)\end{array}$ & $\begin{array}{c}9.83 \mathrm{E}-4 \\
(1.886)\end{array}$ & $\begin{array}{l}1.63 \mathrm{E}-3 \\
(3.124)\end{array}$ & $\begin{array}{c}9.74 \mathrm{E}-4 \\
(1.868)\end{array}$ & $\begin{array}{c}8.23 \mathrm{E}-4 \\
(1.578)\end{array}$ & $\begin{array}{l}1.12 \mathrm{E}-3 \\
(2.141)\end{array}$ & $\begin{array}{c}7.48 \mathrm{E}-3 \\
(14.352)\end{array}$ & $\begin{array}{c}5.58 \mathrm{E}-3 \\
(10.697)\end{array}$ \\
\hline
\end{tabular}

Note: Values are reported as compact inventory fractions and particle-equivalents (in parentheses)

Note: A less-than value indicates that the concentration in the leachate was below the minimum detectable limit; these values are not included in the totals

${ }^{a}$ Postburn particle leach data were scaled to account for $\sim 11 \%$ particle population withheld from postburn analysis 
Appendix Table A-20. Exposed inventory of stable nuclides of interest detected by RDLBL of AGR-3/4 Compact 7-4 Segment 2

\begin{tabular}{|c|c|c|c|c|c|c|c|c|c|c|}
\hline RDLBL Step & ${ }^{105} \mathrm{Pd}$ & ${ }^{109} \mathrm{Ag}$ & ${ }^{133} \mathrm{Cs}$ & ${ }^{139} \mathbf{L a}$ & ${ }^{140} \mathrm{Ce}$ & ${ }^{141} \mathrm{Pr}$ & $146 \mathrm{Nd}$ & ${ }^{152} \mathrm{Sm}$ & ${ }^{153} \mathbf{E u}$ & ${ }^{156}$ Gd \\
\hline Deconsolidation acid & $\begin{array}{l}<6.2 \mathrm{E}-5 \\
<(0.119)\end{array}$ & $\begin{array}{l}1.18 \mathrm{E}-3 \\
(2.271)\end{array}$ & $\begin{array}{c}7.09 \mathrm{E}-5 \\
(0.136)\end{array}$ & $\begin{array}{c}6.39 \mathrm{E}-5 \\
(0.123)\end{array}$ & $\begin{array}{c}6.45 \mathrm{E}-5 \\
(0.124)\end{array}$ & $\begin{array}{c}3.98 \mathrm{E}-5 \\
(0.076)\end{array}$ & $\begin{array}{c}3.42 \mathrm{E}-5 \\
(0.066)\end{array}$ & $\begin{array}{c}1.27 \mathrm{E}-4 \\
(0.245)\end{array}$ & $\begin{array}{l}1.12 \mathrm{E}-3 \\
(2.155)\end{array}$ & $\begin{array}{c}6.84 \mathrm{E}-4 \\
(1.312)\end{array}$ \\
\hline Preburn leach 1 & $\begin{array}{c}1.96 \mathrm{E}-4 \\
(0.376)\end{array}$ & $\begin{array}{c}2.66 \mathrm{E}-4 \\
(0.510)\end{array}$ & $\begin{array}{c}9.30 \mathrm{E}-6 \\
(0.018)\end{array}$ & $\begin{array}{c}5.48 \mathrm{E}-5 \\
(0.105)\end{array}$ & $\begin{array}{c}1.11 \mathrm{E}-4 \\
(0.214)\end{array}$ & $\begin{array}{c}6.61 \mathrm{E}-6 \\
(0.013)\end{array}$ & $\begin{array}{c}5.18 \mathrm{E}-6 \\
(0.0099)\end{array}$ & $\begin{array}{c}4.62 \mathrm{E}-5 \\
(0.089)\end{array}$ & $\begin{array}{c}6.32 \mathrm{E}-4 \\
(1.213)\end{array}$ & $\begin{array}{c}3.20 \mathrm{E}-4 \\
(0.614)\end{array}$ \\
\hline Preburn leach 2 & $\begin{array}{l}<6.3 \mathrm{E}-5 \\
<(0.120)\end{array}$ & $\begin{array}{c}1.59 \mathrm{E}-4 \\
(0.305)\end{array}$ & $\begin{array}{c}3.85 \mathrm{E}-6 \\
(0.0074)\end{array}$ & $\begin{array}{c}7.95 \mathrm{E}-6 \\
(0.015)\end{array}$ & $\begin{array}{c}5.66 \mathrm{E}-5 \\
(0.109)\end{array}$ & $\begin{array}{c}6.14 \mathrm{E}-6 \\
(0.012)\end{array}$ & $\begin{array}{c}5.26 \mathrm{E}-6 \\
(0.010)\end{array}$ & $\begin{array}{l}<2.4 \mathrm{E}-5 \\
<(0.046)\end{array}$ & $\begin{array}{c}6.76 \mathrm{E}-5 \\
(0.130)\end{array}$ & $\begin{array}{l}<5.9 \mathrm{E}-5 \\
<(0.113)\end{array}$ \\
\hline Postburn matrix leach 1 & $\begin{array}{c}6.40 \mathrm{E}-4 \\
(1.228)\end{array}$ & $\begin{array}{l}7.16 \mathrm{E}-4 \\
(1.372)\end{array}$ & $\begin{array}{c}2.09 \mathrm{E}-5 \\
(0.040)\end{array}$ & $\begin{array}{c}8.00 \mathrm{E}-5 \\
(0.153)\end{array}$ & $\begin{array}{c}1.94 \mathrm{E}-4 \\
(0.372)\end{array}$ & $\begin{array}{c}2.74 \mathrm{E}-5 \\
(0.052)\end{array}$ & $\begin{array}{c}2.29 \mathrm{E}-5 \\
(0.044)\end{array}$ & $\begin{array}{c}2.20 \mathrm{E}-4 \\
(0.421)\end{array}$ & $\begin{array}{c}3.23 \mathrm{E}-3 \\
(6.198)\end{array}$ & $\begin{array}{c}1.31 \mathrm{E}-3 \\
(2.509)\end{array}$ \\
\hline Postburn matrix leach 2 & $\begin{array}{l}<2.8 \mathrm{E}-5 \\
<(0.053)\end{array}$ & $\begin{array}{c}8.82 \mathrm{E}-4 \\
(1.691)\end{array}$ & $\begin{array}{c}5.68 \mathrm{E}-6 \\
(0.011)\end{array}$ & $\begin{array}{c}4.34 \mathrm{E}-6 \\
(0.0083)\end{array}$ & $\begin{array}{c}2.25 \mathrm{E}-5 \\
(0.043)\end{array}$ & $\begin{array}{c}2.29 \mathrm{E}-6 \\
(0.0044)\end{array}$ & $\begin{array}{c}1.97 \mathrm{E}-6 \\
(0.0038)\end{array}$ & $\begin{array}{l}<1.1 \mathrm{E}-5 \\
<(0.020)\end{array}$ & $\begin{array}{c}1.04 \mathrm{E}-4 \\
(0.200)\end{array}$ & $\begin{array}{c}5.14 \mathrm{E}-5 \\
(0.099)\end{array}$ \\
\hline Postburn particle leach $1^{a}$ & $\begin{array}{c}3.77 \mathrm{E}-4 \\
(0.723)\end{array}$ & $\begin{array}{c}5.27 \mathrm{E}-4 \\
(1.011)\end{array}$ & $\begin{array}{c}3.78 \mathrm{E}-5 \\
(0.073)\end{array}$ & $\begin{array}{c}6.15 \mathrm{E}-5 \\
(0.118)\end{array}$ & $\begin{array}{c}2.93 \mathrm{E}-4 \\
(0.562)\end{array}$ & $\begin{array}{c}1.33 \mathrm{E}-4 \\
(0.255)\end{array}$ & $\begin{array}{c}9.84 \mathrm{E}-5 \\
(0.189)\end{array}$ & $\begin{array}{c}1.63 \mathrm{E}-4 \\
(0.313)\end{array}$ & $\begin{array}{c}1.42 \mathrm{E}-3 \\
(2.717)\end{array}$ & $\begin{array}{c}1.16 \mathrm{E}-3 \\
(2.232)\end{array}$ \\
\hline Postburn particle leach $2^{a}$ & $\begin{array}{c}6.27 \mathrm{E}-5 \\
(0.120)\end{array}$ & $\begin{array}{c}1.58 \mathrm{E}-4 \\
(0.304)\end{array}$ & $\begin{array}{c}8.46 \mathrm{E}-6 \\
(0.016)\end{array}$ & $\begin{array}{c}4.53 \mathrm{E}-6 \\
(0.0087)\end{array}$ & $\begin{array}{c}7.36 \mathrm{E}-5 \\
(0.141)\end{array}$ & $\begin{array}{c}7.28 \mathrm{E}-6 \\
(0.014)\end{array}$ & $\begin{array}{c}7.25 \mathrm{E}-6 \\
(0.014)\end{array}$ & $\begin{array}{l}<1.9 \mathrm{E}-5 \\
<(0.037)\end{array}$ & $\begin{array}{c}3.18 \mathrm{E}-5 \\
(0.061)\end{array}$ & $\begin{array}{c}6.72 \mathrm{E}-5 \\
(0.129)\end{array}$ \\
\hline Total & $\begin{array}{l}1.28 \mathrm{E}-3 \\
(2.448)\end{array}$ & $\begin{array}{c}3.89 \mathrm{E}-3 \\
(7.465)\end{array}$ & $\begin{array}{c}1.57 \mathrm{E}-4 \\
(0.301)\end{array}$ & $\begin{array}{c}2.77 \mathrm{E}-4 \\
(0.531)\end{array}$ & $\begin{array}{c}8.16 \mathrm{E}-4 \\
(1.564)\end{array}$ & $\begin{array}{c}2.22 \mathrm{E}-4 \\
(0.426)\end{array}$ & $\begin{array}{c}1.75 \mathrm{E}-4 \\
(0.336)\end{array}$ & $\begin{array}{c}5.57 \mathrm{E}-4 \\
(1.068)\end{array}$ & $\begin{array}{c}6.61 \mathrm{E}-3 \\
(12.673)\end{array}$ & $\begin{array}{c}3.59 \mathrm{E}-3 \\
(6.895)\end{array}$ \\
\hline
\end{tabular}

Note: Values are reported as compact inventory fractions and particle-equivalents (in parentheses)

Note: A less-than value indicates that the concentration in the leachate was below the minimum detectable limit; these values are not included in the totals

${ }^{a}$ Postburn particle leach data were scaled to account for $\sim 11 \%$ particle population withheld from postburn analysis 
Appendix Table A-21. Exposed inventory of stable nuclides of interest detected by RDLBL of AGR-3/4 Compact 7-4 Segment 3

\begin{tabular}{|c|c|c|c|c|c|c|c|c|c|c|}
\hline RDLBL Step & ${ }^{105} \mathrm{Pd}$ & ${ }^{109} \mathrm{Ag}$ & ${ }^{133} \mathrm{Cs}$ & ${ }^{139} \mathbf{L a}$ & ${ }^{140} \mathrm{Ce}$ & ${ }^{141} \mathrm{Pr}$ & ${ }^{146} \mathrm{Nd}$ & ${ }^{152} \mathrm{Sm}$ & ${ }^{153} \mathbf{E u}$ & ${ }^{156} \mathrm{Gd}$ \\
\hline Deconsolidation acid & $\begin{array}{l}1.02 \mathrm{E}-4 \\
(0.196)\end{array}$ & $\begin{array}{c}3.38 \mathrm{E}-3 \\
(6.488)\end{array}$ & $\begin{array}{c}2.04 \mathrm{E}-3 \\
(3.921)\end{array}$ & $\begin{array}{c}2.34 \mathrm{E}-3 \\
(4.490)\end{array}$ & $\begin{array}{c}2.14 \mathrm{E}-3 \\
(4.101)\end{array}$ & $\begin{array}{c}2.12 \mathrm{E}-3 \\
(4.074)\end{array}$ & $\begin{array}{c}1.82 \mathrm{E}-3 \\
(3.489)\end{array}$ & $\begin{array}{c}1.86 \mathrm{E}-3 \\
(3.571)\end{array}$ & $\begin{array}{c}2.52 \mathrm{E}-3 \\
(4.827)\end{array}$ & $\begin{array}{c}3.40 \mathrm{E}-3 \\
(6.512)\end{array}$ \\
\hline Preburn leach 1 & $\begin{array}{c}3.97 \mathrm{E}-4 \\
(0.762)\end{array}$ & $\begin{array}{c}5.95 \mathrm{E}-4 \\
(1.141)\end{array}$ & $\begin{array}{c}2.71 \mathrm{E}-4 \\
(0.520)\end{array}$ & $\begin{array}{c}1.09 \mathrm{E}-3 \\
(2.084)\end{array}$ & $\begin{array}{l}1.18 \mathrm{E}-3 \\
(2.269)\end{array}$ & $\begin{array}{c}1.06 \mathrm{E}-3 \\
(2.034)\end{array}$ & $\begin{array}{c}8.89 \mathrm{E}-4 \\
(1.705)\end{array}$ & $\begin{array}{c}8.63 \mathrm{E}-4 \\
(1.656)\end{array}$ & $\begin{array}{c}1.49 \mathrm{E}-3 \\
(2.852)\end{array}$ & $\begin{array}{c}1.53 \mathrm{E}-3 \\
(2.937)\end{array}$ \\
\hline Preburn leach 2 & $\begin{array}{l}<5.6 \mathrm{E}-5 \\
<(0.108)\end{array}$ & $\begin{array}{c}1.16 \mathrm{E}-4 \\
(0.223)\end{array}$ & $\begin{array}{c}5.17 \mathrm{E}-5 \\
(0.099)\end{array}$ & $\begin{array}{c}1.56 \mathrm{E}-4 \\
(0.300)\end{array}$ & $\begin{array}{c}2.09 \mathrm{E}-4 \\
(0.401)\end{array}$ & $\begin{array}{c}1.56 \mathrm{E}-4 \\
(0.298)\end{array}$ & $\begin{array}{c}1.32 \mathrm{E}-4 \\
(0.252)\end{array}$ & $\begin{array}{c}9.29 \mathrm{E}-5 \\
(0.178)\end{array}$ & $\begin{array}{c}1.61 \mathrm{E}-4 \\
(0.310)\end{array}$ & $\begin{array}{c}2.12 \mathrm{E}-4 \\
(0.406)\end{array}$ \\
\hline Postburn matrix leach 1 & $\begin{array}{l}1.48 \mathrm{E}-3 \\
(2.835)\end{array}$ & $\begin{array}{c}5.67 \mathrm{E}-4 \\
(1.087)\end{array}$ & $\begin{array}{c}9.56 \mathrm{E}-5 \\
(0.183)\end{array}$ & $\begin{array}{c}2.41 \mathrm{E}-3 \\
(4.617)\end{array}$ & $\begin{array}{c}2.47 \mathrm{E}-3 \\
(4.741)\end{array}$ & $\begin{array}{c}2.45 \mathrm{E}-3 \\
(4.690)\end{array}$ & $\begin{array}{c}2.10 \mathrm{E}-3 \\
(4.035)\end{array}$ & $\begin{array}{c}3.22 \mathrm{E}-3 \\
(6.179)\end{array}$ & $\begin{array}{c}7.54 \mathrm{E}-3 \\
(14.471)\end{array}$ & $\begin{array}{r}4.83 \mathrm{E}-3 \\
(9.260)\end{array}$ \\
\hline Postburn matrix leach 2 & $\begin{array}{l}<2.9 \mathrm{E}-5 \\
<(0.056)\end{array}$ & $\begin{array}{c}6.87 \mathrm{E}-5 \\
(0.132)\end{array}$ & $\begin{array}{c}9.12 \mathrm{E}-6 \\
(0.017)\end{array}$ & $\begin{array}{c}2.36 \mathrm{E}-5 \\
(0.045)\end{array}$ & $\begin{array}{c}3.34 \mathrm{E}-5 \\
(0.064)\end{array}$ & $\begin{array}{c}2.46 \mathrm{E}-5 \\
(0.047)\end{array}$ & $\begin{array}{c}2.09 \mathrm{E}-5 \\
(0.040)\end{array}$ & $\begin{array}{c}3.04 \mathrm{E}-5 \\
(0.058)\end{array}$ & $\begin{array}{c}7.56 \mathrm{E}-5 \\
(0.145)\end{array}$ & $\begin{array}{c}5.25 \mathrm{E}-5 \\
(0.101)\end{array}$ \\
\hline Postburn particle leach $1^{a}$ & $\begin{array}{c}9.95 \mathrm{E}-4 \\
(1.908)\end{array}$ & $\begin{array}{c}1.00 \mathrm{E}-3 \\
(1.922)\end{array}$ & $\begin{array}{c}2.08 \mathrm{E}-5 \\
(0.040)\end{array}$ & $\begin{array}{c}2.05 \mathrm{E}-3 \\
(3.937)\end{array}$ & $\begin{array}{c}3.77 \mathrm{E}-3 \\
(7.226)\end{array}$ & $\begin{array}{c}3.77 \mathrm{E}-3 \\
(7.223)\end{array}$ & $\begin{array}{c}3.28 \mathrm{E}-3 \\
(6.294)\end{array}$ & $\begin{array}{c}3.20 \mathrm{E}-3 \\
(6.144)\end{array}$ & $\begin{array}{c}4.34 \mathrm{E}-3 \\
(8.323)\end{array}$ & $\begin{array}{c}5.07 \mathrm{E}-3 \\
(9.733)\end{array}$ \\
\hline Postburn particle leach $2^{a}$ & $\begin{array}{l}1.36 \mathrm{E}-4 \\
(0.261)\end{array}$ & $\begin{array}{c}9.04 \mathrm{E}-5 \\
(0.173)\end{array}$ & $\begin{array}{c}9.02 \mathrm{E}-6 \\
(0.017)\end{array}$ & $\begin{array}{c}1.69 \mathrm{E}-5 \\
(0.032)\end{array}$ & $\begin{array}{c}1.82 \mathrm{E}-4 \\
(0.350)\end{array}$ & $\begin{array}{c}2.96 \mathrm{E}-5 \\
(0.057)\end{array}$ & $\begin{array}{c}2.70 \mathrm{E}-5 \\
(0.052)\end{array}$ & $\begin{array}{c}2.39 \mathrm{E}-5 \\
(0.046)\end{array}$ & $\begin{array}{c}4.19 \mathrm{E}-5 \\
(0.080)\end{array}$ & $\begin{array}{c}1.30 \mathrm{E}-4 \\
(0.249)\end{array}$ \\
\hline Total & $\begin{array}{c}3.11 \mathrm{E}-3 \\
(5.961)\end{array}$ & $\begin{array}{c}5.26 \mathrm{E}-3 \\
(10.085)\end{array}$ & $\begin{array}{c}2.27 \mathrm{E}-3 \\
(4.349)\end{array}$ & $\begin{array}{c}7.98 \mathrm{E}-3 \\
(15.296)\end{array}$ & $\begin{array}{c}9.89 \mathrm{E}-3 \\
(18.961)\end{array}$ & $\begin{array}{c}9.52 \mathrm{E}-3 \\
(18.253)\end{array}$ & $\begin{array}{c}8.19 \mathrm{E}-3 \\
(15.716)\end{array}$ & $\begin{array}{c}9.15 \mathrm{E}-3 \\
(17.557)\end{array}$ & $\begin{array}{c}1.57 \mathrm{E}-2 \\
(30.207)\end{array}$ & $\begin{array}{c}1.49 \mathrm{E}-2 \\
(28.512)\end{array}$ \\
\hline
\end{tabular}

Note: Values are reported as compact inventory fractions and particle-equivalents (in parentheses)

Note: A less-than value indicates that the concentration in the leachate was below the minimum detectable limit; these values are not included in the totals

${ }^{a}$ Postburn particle leach data were scaled to account for $\sim 11 \%$ particle population withheld from postburn analysis 
Appendix Table A-22. Concentration in each segment from AGR-3/4 Compact 8-4

\begin{tabular}{|c|c|c|c|c|}
\hline Nuclide & Segment 1 & Segment 2 & Segment 3 & Segment 4 \\
\hline${ }^{235} \mathbf{U}$ & $6.96 \mathrm{E}-4 \quad(1.334)$ & $1.66 \mathrm{E}-3 \quad(3.184)$ & $1.33 \mathrm{E}-3 \quad(2.547)$ & $1.72 \mathrm{E}-2 \quad(32.900)$ \\
\hline${ }^{236} \mathbf{U}$ & $6.78 \mathrm{E}-4 \quad(1.300)$ & $1.57 \mathrm{E}-3 \quad(3.017)$ & $1.21 \mathrm{E}-3 \quad(2.329)$ & $1.62 \mathrm{E}-2 \quad(31.017)$ \\
\hline${ }^{238} \mathbf{U}$ & $7.93 \mathrm{E}-4 \quad(1.521)$ & $1.71 \mathrm{E}-3 \quad(3.285)$ & $1.43 \mathrm{E}-3 \quad(2.750)$ & $1.63 \mathrm{E}-2 \quad(31.218)$ \\
\hline${ }^{239} \mathrm{Pu}$ & $3.26 \mathrm{E}-4 \quad(0.626)$ & $9.55 \mathrm{E}-4 \quad(1.831)$ & 9.33E-4 (1.789) & $1.68 \mathrm{E}-2 \quad(32.195)$ \\
\hline${ }^{240} \mathrm{Pu}$ & $2.69 \mathrm{E}-4 \quad(0.515)$ & $9.28 \mathrm{E}-4 \quad(1.780)$ & $1.03 \mathrm{E}-3 \quad(1.971)$ & $1.73 \mathrm{E}-2 \quad(33.164)$ \\
\hline${ }^{90} \mathrm{Sr}$ & $3.16 \mathrm{E}-3 \quad(6.054)$ & $9.46 \mathrm{E}-3 \quad(18.143)$ & $1.24 \mathrm{E}-2 \quad(23.863)$ & $1.42 \mathrm{E}-2 \quad(27.276)$ \\
\hline${ }^{106} \mathrm{Ru}$ & $2.31 \mathrm{E}-4 \quad(0.443)$ & $5.73 \mathrm{E}-4 \quad(1.098)$ & $3.36 \mathrm{E}-4 \quad(0.645)$ & $1.21 \mathrm{E}-2 \quad(23.257)$ \\
\hline${ }^{110 \mathrm{~m}} \mathrm{Ag}$ & $0.00 \mathrm{E}+0 \quad(0.000)$ & $0.00 \mathrm{E}+0 \quad(0.000)$ & $0.00 \mathrm{E}+0 \quad(0.000)$ & $0.00 \mathrm{E}+0 \quad(0.000)$ \\
\hline${ }^{125} \mathrm{Sb}$ & $2.15 \mathrm{E}-4 \quad(0.413)$ & $3.30 \mathrm{E}-4 \quad(0.634)$ & $3.39 \mathrm{E}-4 \quad(0.650)$ & $2.86 \mathrm{E}-3 \quad(5.494)$ \\
\hline${ }^{134} \mathrm{Cs}$ & $3.00 \mathrm{E}-5 \quad(0.058)$ & $7.14 \mathrm{E}-5 \quad(0.137)$ & $4.32 \mathrm{E}-5 \quad(0.083)$ & $5.58 \mathrm{E}-4 \quad(1.070)$ \\
\hline${ }^{137} \mathrm{Cs}$ & $1.40 \mathrm{E}-4 \quad(0.268)$ & $3.00 \mathrm{E}-4 \quad(0.576)$ & $1.83 \mathrm{E}-4 \quad(0.352)$ & $2.48 \mathrm{E}-3 \quad(4.763)$ \\
\hline${ }^{144} \mathrm{Ce}$ & $8.43 \mathrm{E}-5 \quad(0.162)$ & $3.43 \mathrm{E}-4 \quad(0.658)$ & $4.78 \mathrm{E}-4 \quad(0.917)$ & $2.04 \mathrm{E}-2 \quad(39.038)$ \\
\hline${ }^{154} \mathbf{E u}$ & $4.24 \mathrm{E}-3 \quad(8.124)$ & $1.07 \mathrm{E}-2 \quad(20.463)$ & $1.48 \mathrm{E}-2 \quad(28.313)$ & $1.76 \mathrm{E}-2 \quad(33.677)$ \\
\hline${ }^{155} \mathrm{Eu}$ & $4.89 \mathrm{E}-3 \quad(9.373)$ & $1.22 \mathrm{E}-2 \quad(23.475)$ & $1.52 \mathrm{E}-2 \quad(29.246)$ & $2.01 \mathrm{E}-2 \quad(38.474)$ \\
\hline${ }^{105} \mathrm{Pd}$ & $1.08 \mathrm{E}-3 \quad(2.068)$ & $1.52 \mathrm{E}-3 \quad(2.915)$ & $5.62 \mathrm{E}-3 \quad(10.779)$ & $4.82 \mathrm{E}-3 \quad(9.245)$ \\
\hline${ }^{109} \mathrm{Ag}$ & $8.11 \mathrm{E}-3 \quad(15.559)$ & $2.54 \mathrm{E}-2 \quad(48.637)$ & $3.30 \mathrm{E}-2 \quad(63.321)$ & $2.65 \mathrm{E}-2 \quad(50.872)$ \\
\hline${ }^{133} \mathrm{Cs}$ & $1.75 \mathrm{E}-4 \quad(0.336)$ & $3.56 \mathrm{E}-4 \quad(0.683)$ & $3.32 \mathrm{E}-4 \quad(0.636)$ & $2.47 \mathrm{E}-3 \quad(4.732)$ \\
\hline${ }^{139} \mathbf{L a}$ & $2.30 \mathrm{E}-3 \quad(4.405)$ & $3.97 \mathrm{E}-4 \quad(0.762)$ & 4.33E-4 (0.831) & $1.43 \mathrm{E}-2 \quad(27.442)$ \\
\hline${ }^{140} \mathrm{Ce}$ & $2.08 \mathrm{E}-3 \quad(3.999)$ & $1.18 \mathrm{E}-3 \quad(2.268)$ & $1.51 \mathrm{E}-3 \quad(2.892)$ & $2.06 \mathrm{E}-2 \quad(39.464)$ \\
\hline${ }^{141} \mathrm{Pr}$ & $2.04 \mathrm{E}-4 \quad(0.391)$ & $3.78 \mathrm{E}-4 \quad(0.724)$ & 5.42E-4 (1.040) & $2.00 \mathrm{E}-2 \quad(38.367)$ \\
\hline${ }^{146} \mathrm{Nd}$ & $1.29 \mathrm{E}-4 \quad(0.247)$ & $3.52 \mathrm{E}-4 \quad(0.675)$ & 4.12E-4 (0.790) & $1.68 \mathrm{E}-2 \quad(32.174)$ \\
\hline${ }^{152} \mathrm{Sm}$ & $3.84 \mathrm{E}-4 \quad(0.736)$ & 8.87E-4 (1.702) & $1.59 \mathrm{E}-3 \quad(3.051)$ & $1.79 \mathrm{E}-2 \quad(34.344)$ \\
\hline${ }^{153} \mathbf{E u}$ & $3.36 \mathrm{E}-3 \quad(6.436)$ & $9.56 \mathrm{E}-3 \quad(18.342)$ & $1.44 \mathrm{E}-2 \quad(27.705)$ & $2.08 \mathrm{E}-2 \quad(39.966)$ \\
\hline${ }^{156} \mathrm{Gd}$ & $2.37 \mathrm{E}-3 \quad(4.551)$ & 4.97E-3 (9.540) & $7.66 \mathrm{E}-3 \quad(14.695)$ & $2.88 \mathrm{E}-2 \quad(55.197)$ \\
\hline
\end{tabular}


Appendix Table A-23. Concentration in each segment from AGR-3/4 Compact 7-4

\begin{tabular}{lllllll}
\hline Nuclide & \multicolumn{2}{c}{ Segment 1 } & \multicolumn{2}{c}{ Segment 2 } & \multicolumn{2}{c}{ Segment 3 } \\
\hline${ }^{235} \mathbf{U}$ & $1.93 \mathrm{E}-3$ & $(3.697)$ & $4.14 \mathrm{E}-4$ & $(0.794)$ & $9.39 \mathrm{E}-3$ & $(18.011)$ \\
${ }^{236} \mathbf{U}$ & $2.21 \mathrm{E}-3$ & $(4.237)$ & $4.42 \mathrm{E}-4$ & $(0.847)$ & $9.02 \mathrm{E}-3$ & $(17.303)$ \\
${ }^{238} \mathbf{U}$ & $3.57 \mathrm{E}-3$ & $(6.841)$ & $1.09 \mathrm{E}-3$ & $(2.098)$ & $9.11 \mathrm{E}-3$ & $(17.480)$ \\
${ }^{239} \mathbf{P u}$ & $3.13 \mathrm{E}-3$ & $(6.001)$ & $8.80 \mathrm{E}-4$ & $(1.688)$ & $9.13 \mathrm{E}-3$ & $(17.507)$ \\
${ }^{240} \mathbf{P u}$ & $4.03 \mathrm{E}-3$ & $(7.720)$ & $1.44 \mathrm{E}-3$ & $(2.771)$ & $1.02 \mathrm{E}-2$ & $(19.469)$ \\
\hline${ }^{90} \mathbf{S r}$ & $1.61 \mathrm{E}-2$ & $(30.893)$ & $1.59 \mathrm{E}-2$ & $(30.436)$ & $1.36 \mathrm{E}-2$ & $(25.993)$ \\
${ }^{106} \mathbf{R u}$ & $1.88 \mathrm{E}-3$ & $(3.608)$ & $0.00 \mathrm{E}+0$ & $(0.000)$ & $8.22 \mathrm{E}-3$ & $(15.764)$ \\
${ }^{110 m} \mathbf{A g}$ & $0.00 \mathrm{E}+0$ & $(0.000)$ & $0.00 \mathrm{E}+0$ & $(0.000)$ & $0.00 \mathrm{E}+0$ & $(0.000)$ \\
${ }^{125} \mathbf{S b}$ & $1.44 \mathrm{E}-3$ & $(2.754)$ & $3.21 \mathrm{E}-4$ & $(0.615)$ & $8.42 \mathrm{E}-4$ & $(1.614)$ \\
${ }^{134} \mathbf{C s}$ & $1.02 \mathrm{E}-3$ & $(1.956)$ & $1.68 \mathrm{E}-4$ & $(0.323)$ & $1.46 \mathrm{E}-3$ & $(2.805)$ \\
${ }^{137} \mathbf{C s}$ & $1.65 \mathrm{E}-3$ & $(3.169)$ & $4.44 \mathrm{E}-4$ & $(0.851)$ & $2.82 \mathrm{E}-3$ & $(5.403)$ \\
${ }^{144} \mathbf{C e}$ & $2.05 \mathrm{E}-3$ & $(3.932)$ & $4.94 \mathrm{E}-4$ & $(0.947)$ & $1.09 \mathrm{E}-2$ & $(20.986)$ \\
${ }^{154} \mathbf{E u}$ & $2.17 \mathrm{E}-2$ & $(41.542)$ & $2.13 \mathrm{E}-2$ & $(40.860)$ & $1.67 \mathrm{E}-2$ & $(32.053)$ \\
${ }^{155} \mathbf{E u}$ & $2.38 \mathrm{E}-2$ & $(45.739)$ & $2.36 \mathrm{E}-2$ & $(45.227)$ & $1.87 \mathrm{E}-2$ & $(35.913)$ \\
\hline${ }^{105} \mathbf{P d}$ & $5.98 \mathrm{E}-3$ & $(11.464)$ & $4.36 \mathrm{E}-3$ & $(8.364)$ & $3.82 \mathrm{E}-3$ & $(7.320)$ \\
${ }^{109} \mathbf{A g}$ & $7.99 \mathrm{E}-3$ & $(15.325)$ & $1.33 \mathrm{E}-2$ & $(25.503)$ & $6.46 \mathrm{E}-3$ & $(12.384)$ \\
${ }^{133} \mathbf{C s}$ & $1.57 \mathrm{E}-3$ & $(3.013)$ & $5.36 \mathrm{E}-4$ & $(1.028)$ & $2.78 \mathrm{E}-3$ & $(5.341)$ \\
${ }^{139} \mathbf{L a}$ & $2.98 \mathrm{E}-3$ & $(5.715)$ & $9.47 \mathrm{E}-4$ & $(1.816)$ & $9.79 \mathrm{E}-3$ & $(18.784)$ \\
${ }^{140} \mathbf{C e}$ & $4.94 \mathrm{E}-3$ & $(9.467)$ & $2.79 \mathrm{E}-3$ & $(5.344)$ & $1.21 \mathrm{E}-2$ & $(23.284)$ \\
${ }^{141} \mathbf{P r}$ & $2.95 \mathrm{E}-3$ & $(5.661)$ & $7.59 \mathrm{E}-4$ & $(1.457)$ & $1.17 \mathrm{E}-2$ & $(22.416)$ \\
${ }^{146} \mathbf{N d}$ & $2.49 \mathrm{E}-3$ & $(4.781)$ & $5.98 \mathrm{E}-4$ & $(1.147)$ & $1.01 \mathrm{E}-2$ & $(19.300)$ \\
${ }^{152} \mathbf{S m}$ & $3.38 \mathrm{E}-3$ & $(6.489)$ & $1.90 \mathrm{E}-3$ & $(3.649)$ & $1.12 \mathrm{E}-2$ & $(21.561)$ \\
${ }^{153} \mathbf{E u}$ & $2.27 \mathrm{E}-2$ & $(43.488)$ & $2.26 \mathrm{E}-2$ & $(43.295)$ & $1.93 \mathrm{E}-2$ & $(37.095)$ \\
${ }^{156} \mathbf{G d}$ & $1.69 \mathrm{E}-2$ & $(32.414)$ & $1.23 \mathrm{E}-2$ & $(23.555)$ & $1.83 \mathrm{E}-2$ & $(35.014)$ \\
\hline${ }^{N o t e}:$ Values are & reported as compact fraction/cm 3 and particle-equivalents/cm 3 (in parentheses)
\end{tabular}




\section{APPENDIX B. IMGA DATA}





\section{APPENDIX B. IMGA DATA ${ }^{4}$}

The tables in this appendix document the IMGA data for key gamma-emitting fission products. Values are reported as measured activities in units of $\mathrm{Bq}$ that have been decay-corrected to one day after EOL and as various unitless ratios, as described in Section 0. The M/A values, as shown in Eq. (0.1), are indicative of particle-to-particle variation in isotopic content. For particles with negligible radionuclide release, this particle-to-particle variation may be related to variation in fissionable material and/or burnup. Fissionable material in an as-fabricated particle may vary due to variation in kernel size (e.g., spherical kernels with different diameters or fragmented kernels), variation in kernel uranium fraction, and/or variation in uranium enrichment. Variation in local neutron fluence will cause a variation in burnup between spatially separated particles, even if the physical properties of the particles are identical. The M/AA values, as shown in Eq. (0.4), are adjusted using a normally well-retained nuclide to attempt to separate the variation in M/A as a function of fission product retention from the variation as a function of fissionable material and/or burnup. (Note that ${ }^{144} \mathrm{Ce}$ was used for the M/AA values reported herein). This makes the M/AA values indicative of the fission product retention in a particle relative to the average of all measured RS particles. Particles with M/AA near unity for a given nuclide exhibited close-to-average retention of that nuclide. However, if a given nuclide were released from a large fraction of particles, then an M/AA value of unity would not indicate good retention of that nuclide. Such was often the case for ${ }^{110 \mathrm{~m}} \mathrm{Ag}$ in particles from the AGR-1 and AGR-2 experiments (Demkowicz et al. 2016, Hunn et al. 2018). As shown in Eq. 0.3 , the $\mathrm{M} / \mathrm{C}$ values provide an indication of the particle inventory relative to the average calculated inventory (0). For well-retained nuclides, the mean $\mathrm{M} / \mathrm{C}$ values are typically $1.00 \pm 0.10$, whereas the variation is mostly the result of error in the calculated average inventories stemming from uncertainty in the values used for the calculation. For the AGR-1 and AGR-2 irradiations, the mean M/C values for ${ }^{125} \mathrm{Sb}$ and ${ }^{154} \mathrm{Eu}$ have been consistently offset from unity by more than $10 \%$ as a result of larger errors in the calculated values.

${ }^{4}$ This appendix is a revised version of a similar appendix in a previous AGR-3/4 PIE report (Hunn and Montgomery, 2020) and is duplicated herein to maintain a consistent format in documenting similar data. 
Appendix Table B-1. Radionuclide inventories of particles from AGR-3/4 Compact 7-4

\begin{tabular}{|c|c|c|c|c|c|c|c|}
\hline Particle & Value & ${ }^{106} \mathrm{Ru}$ & ${ }^{125} \mathrm{Sb}$ & ${ }^{134} \mathrm{Cs}$ & ${ }^{137} \mathrm{Cs}$ & ${ }^{144} \mathrm{Ce}$ & ${ }^{154} \mathbf{E u}$ \\
\hline 074-S3-SP02 & $\mathrm{Bq}$ & $5.42 \mathrm{E}+5$ & $2.77 \mathrm{E}+3$ & $6.81 \mathrm{E}+5$ & $6.41 \mathrm{E}+5$ & $0.00 \mathrm{E}+0$ & $4.83 \mathrm{E}+4$ \\
\hline 074-S3-SP02 & $\mathrm{M} / \mathrm{A}$ & $3.54 \mathrm{E}-2$ & $1.32 \mathrm{E}-2$ & $1.35 \mathrm{E}-1$ & $1.57 \mathrm{E}-1$ & $0.00 \mathrm{E}+0$ & $3.32 \mathrm{E}-1$ \\
\hline 074-S3-SP02 & $\mathrm{M} / \mathrm{AA}$ & $2.25 \mathrm{E}-1$ & 8.37E-2 & $8.61 \mathrm{E}-1$ & $1.00 \mathrm{E}+0$ & $0.00 \mathrm{E}+0$ & $2.11 \mathrm{E}+0$ \\
\hline 074-S3-SP02 & $\mathrm{M} / \mathrm{C}$ & $2.49 \mathrm{E}-1$ & $5.65 \mathrm{E}-2$ & $8.41 \mathrm{E}-1$ & $1.04 \mathrm{E}+0$ & $0.00 \mathrm{E}+0$ & $1.94 \mathrm{E}+0$ \\
\hline 074-S3-SP03 & $\mathrm{Bq}$ & $7.67 \mathrm{E}+5$ & $8.16 \mathrm{E}+3$ & $1.77 \mathrm{E}+4$ & $1.20 \mathrm{E}+5$ & $8.52 \mathrm{E}+6$ & $1.17 \mathrm{E}+4$ \\
\hline 074-S3-SP03 & $\mathrm{M} / \mathrm{A}$ & $5.00 \mathrm{E}-2$ & $3.88 \mathrm{E}-2$ & $3.53 \mathrm{E}-3$ & $2.95 \mathrm{E}-2$ & $1.47 \mathrm{E}-1$ & $8.04 \mathrm{E}-2$ \\
\hline 074-S3-SP03 & M/AA & $1.70 \mathrm{E}+0$ & $1.32 \mathrm{E}+0$ & $1.20 \mathrm{E}-1$ & $1.00 \mathrm{E}+0$ & $4.99 \mathrm{E}+0$ & $2.73 \mathrm{E}+0$ \\
\hline 074-S3-SP03 & $\mathrm{M} / \mathrm{C}$ & $1.88 \mathrm{E}+0$ & $8.88 \mathrm{E}-1$ & $1.17 \mathrm{E}-1$ & $1.04 \mathrm{E}+0$ & $4.98 \mathrm{E}+0$ & $2.50 \mathrm{E}+0$ \\
\hline 074-S1-RS01 & $\mathrm{Bq}$ & $1.37 \mathrm{E}+7$ & $1.70 \mathrm{E}+5$ & $4.12 \mathrm{E}+6$ & $3.35 \mathrm{E}+6$ & $4.92 \mathrm{E}+7$ & $1.25 \mathrm{E}+5$ \\
\hline 074-S1-RS01 & $\mathrm{M} / \mathrm{A}$ & $8.92 \mathrm{E}-1$ & 8.07E-1 & $8.18 \mathrm{E}-1$ & $8.22 \mathrm{E}-1$ & $8.50 \mathrm{E}-1$ & $8.56 \mathrm{E}-1$ \\
\hline 074-S1-RS01 & M/AA & $1.08 \mathrm{E}+0$ & $9.82 \mathrm{E}-1$ & $9.95 \mathrm{E}-1$ & $1.00 \mathrm{E}+0$ & $1.03 \mathrm{E}+0$ & $1.04 \mathrm{E}+0$ \\
\hline 074-S1-RS01 & $\mathrm{M} / \mathrm{C}$ & $1.20 \mathrm{E}+0$ & $6.63 \mathrm{E}-1$ & $9.73 \mathrm{E}-1$ & $1.04 \mathrm{E}+0$ & $1.03 \mathrm{E}+0$ & $9.55 \mathrm{E}-1$ \\
\hline 074-S1-RS02 & $\mathrm{Bq}$ & $1.97 \mathrm{E}+7$ & $2.66 \mathrm{E}+5$ & $6.09 \mathrm{E}+6$ & $5.06 \mathrm{E}+6$ & $6.97 \mathrm{E}+7$ & $1.74 \mathrm{E}+5$ \\
\hline 1-RS02 & $\mathrm{M} / \mathrm{A}$ & $1.28 \mathrm{E}+0$ & $1.26 \mathrm{E}+0$ & $1.21 \mathrm{E}+0$ & $1.24 \mathrm{E}+0$ & $1.21 \mathrm{E}+0$ & $1.19 \mathrm{E}+0$ \\
\hline 074-S1-RS02 & M/AA & $1.03 \mathrm{E}+0$ & $1.02 \mathrm{E}+0$ & $9.76 \mathrm{E}-1$ & $1.00 \mathrm{E}+0$ & $9.72 \mathrm{E}-1$ & $9.62 \mathrm{E}-1$ \\
\hline 074-S1-RS02 & $\mathrm{M} / \mathrm{C}$ & $1.14 \mathrm{E}+0$ & $6.87 \mathrm{E}-1$ & $9.54 \mathrm{E}-1$ & $1.04 \mathrm{E}+0$ & $9.69 \mathrm{E}-1$ & $8.82 \mathrm{E}-1$ \\
\hline 074-S1-RS03 & $\mathrm{Bq}$ & $1.58 \mathrm{E}+7$ & $2.06 \mathrm{E}+5$ & $5.00 \mathrm{E}+6$ & $4.02 \mathrm{E}+6$ & $6.02 \mathrm{E}+7$ & $1.50 \mathrm{E}+5$ \\
\hline 074-S1-RS03 & $\mathrm{M} / \mathrm{A}$ & $1.03 \mathrm{E}+0$ & $9.77 \mathrm{E}-1$ & $9.94 \mathrm{E}-1$ & $9.87 \mathrm{E}-1$ & $1.04 \mathrm{E}+0$ & $1.03 \mathrm{E}+0$ \\
\hline 074-S1-RS03 & M/AA & $1.04 \mathrm{E}+0$ & $9.89 \mathrm{E}-1$ & $1.01 \mathrm{E}+0$ & $1.00 \mathrm{E}+0$ & $1.05 \mathrm{E}+0$ & $1.04 \mathrm{E}+0$ \\
\hline 074-S1-RS03 & $\mathrm{M} / \mathrm{C}$ & $1.15 \mathrm{E}+0$ & $6.68 \mathrm{E}-1$ & $9.84 \mathrm{E}-1$ & $1.04 \mathrm{E}+0$ & $1.05 \mathrm{E}+0$ & $9.57 \mathrm{E}-1$ \\
\hline 074-S1-RS04 & $\mathrm{Bq}$ & $1.71 \mathrm{E}+7$ & $2.34 \mathrm{E}+5$ & $5.43 \mathrm{E}+6$ & $4.32 \mathrm{E}+6$ & $6.31 \mathrm{E}+7$ & $1.59 \mathrm{E}+5$ \\
\hline 074-S1-RS04 & $\mathrm{M} / \mathrm{A}$ & $1.12 \mathrm{E}+0$ & $1.11 \mathrm{E}+0$ & $1.08 \mathrm{E}+0$ & $1.06 \mathrm{E}+0$ & $1.09 \mathrm{E}+0$ & $1.09 \mathrm{E}+0$ \\
\hline 074-S1-RS04 & M/AA & $1.05 \mathrm{E}+0$ & $1.05 \mathrm{E}+0$ & $1.02 \mathrm{E}+0$ & $1.00 \mathrm{E}+0$ & $1.03 \mathrm{E}+0$ & $1.03 \mathrm{E}+0$ \\
\hline 074-S1-RS04 & $\mathrm{M} / \mathrm{C}$ & $1.16 \mathrm{E}+0$ & 7.07E-1 & $9.95 \mathrm{E}-1$ & $1.04 \mathrm{E}+0$ & $1.03 \mathrm{E}+0$ & $9.43 \mathrm{E}-1$ \\
\hline 074-S1-RS05 & $\mathrm{Bq}$ & $1.69 \mathrm{E}+7$ & $2.31 \mathrm{E}+5$ & $5.18 \mathrm{E}+6$ & $4.29 \mathrm{E}+6$ & $6.07 \mathrm{E}+7$ & $1.54 \mathrm{E}+5$ \\
\hline 074-S1-RS05 & $\mathrm{M} / \mathrm{A}$ & $1.10 \mathrm{E}+0$ & $1.10 \mathrm{E}+0$ & $1.03 \mathrm{E}+0$ & $1.05 \mathrm{E}+0$ & $1.05 \mathrm{E}+0$ & $1.06 \mathrm{E}+0$ \\
\hline 074-S1-RS05 & M/AA & $1.05 \mathrm{E}+0$ & $1.04 \mathrm{E}+0$ & $9.78 \mathrm{E}-1$ & $1.00 \mathrm{E}+0$ & $9.97 \mathrm{E}-1$ & $1.00 \mathrm{E}+0$ \\
\hline 074-S1-RS05 & $\mathrm{M} / \mathrm{C}$ & $1.16 \mathrm{E}+0$ & 7.04E-1 & $9.56 \mathrm{E}-1$ & $1.04 \mathrm{E}+0$ & $9.94 \mathrm{E}-1$ & $9.20 \mathrm{E}-1$ \\
\hline 074-S1-RS06 & $\mathrm{Bq}$ & $1.62 \mathrm{E}+7$ & $2.25 \mathrm{E}+5$ & $5.44 \mathrm{E}+6$ & $4.36 \mathrm{E}+6$ & $6.16 \mathrm{E}+7$ & $1.55 \mathrm{E}+5$ \\
\hline 074-S1-RS06 & $\mathrm{M} / \mathrm{A}$ & $1.06 \mathrm{E}+0$ & $1.07 \mathrm{E}+0$ & $1.08 \mathrm{E}+0$ & $1.07 \mathrm{E}+0$ & $1.06 \mathrm{E}+0$ & $1.06 \mathrm{E}+0$ \\
\hline 074-S1-RS06 & M/AA & $9.91 \mathrm{E}-1$ & $1.00 \mathrm{E}+0$ & $1.01 \mathrm{E}+0$ & $1.00 \mathrm{E}+0$ & $9.95 \mathrm{E}-1$ & $9.93 \mathrm{E}-1$ \\
\hline 074-S1-RS06 & $\mathrm{M} / \mathrm{C}$ & $1.10 \mathrm{E}+0$ & $6.75 \mathrm{E}-1$ & $9.90 \mathrm{E}-1$ & $1.04 \mathrm{E}+0$ & $9.93 \mathrm{E}-1$ & $9.10 \mathrm{E}-1$ \\
\hline 074-S1-RS07 & $\mathrm{Bq}$ & $1.78 \mathrm{E}+7$ & $2.39 \mathrm{E}+5$ & $5.78 \mathrm{E}+6$ & $4.55 \mathrm{E}+6$ & $6.72 \mathrm{E}+7$ & $1.66 \mathrm{E}+5$ \\
\hline 074-S1-RS07 & $\mathrm{M} / \mathrm{A}$ & $1.16 \mathrm{E}+0$ & $1.14 \mathrm{E}+0$ & $1.15 \mathrm{E}+0$ & $1.12 \mathrm{E}+0$ & $1.16 \mathrm{E}+0$ & $1.14 \mathrm{E}+0$ \\
\hline 074-S1-RS07 & M/AA & $1.04 \mathrm{E}+0$ & $1.02 \mathrm{E}+0$ & $1.03 \mathrm{E}+0$ & $1.00 \mathrm{E}+0$ & $1.04 \mathrm{E}+0$ & $1.02 \mathrm{E}+0$ \\
\hline 074-S1-RS07 & $\mathrm{M} / \mathrm{C}$ & $1.15 \mathrm{E}+0$ & $6.87 \mathrm{E}-1$ & $1.01 \mathrm{E}+0$ & $1.04 \mathrm{E}+0$ & $1.04 \mathrm{E}+0$ & $9.38 \mathrm{E}-1$ \\
\hline 074-S1-RS08 & $\mathrm{Bq}$ & $1.65 \mathrm{E}+7$ & $2.32 \mathrm{E}+5$ & $5.23 \mathrm{E}+6$ & $4.33 \mathrm{E}+6$ & $5.98 \mathrm{E}+7$ & $1.52 \mathrm{E}+5$ \\
\hline 074-S1-RS08 & $\mathrm{M} / \mathrm{A}$ & $1.08 \mathrm{E}+0$ & $1.10 \mathrm{E}+0$ & $1.04 \mathrm{E}+0$ & $1.06 \mathrm{E}+0$ & $1.03 \mathrm{E}+0$ & $1.04 \mathrm{E}+0$ \\
\hline 074-S1-RS08 & M/AA & $1.02 \mathrm{E}+0$ & $1.04 \mathrm{E}+0$ & $9.79 \mathrm{E}-1$ & $1.00 \mathrm{E}+0$ & $9.73 \mathrm{E}-1$ & $9.80 \mathrm{E}-1$ \\
\hline 074-S1-RS08 & $\mathrm{M} / \mathrm{C}$ & $1.12 \mathrm{E}+0$ & $7.02 \mathrm{E}-1$ & $9.57 \mathrm{E}-1$ & $1.04 \mathrm{E}+0$ & $9.70 \mathrm{E}-1$ & $8.99 \mathrm{E}-1$ \\
\hline 074-S1-RS09 & $\mathrm{Bq}$ & $1.71 \mathrm{E}+7$ & $2.42 \mathrm{E}+5$ & $5.53 \mathrm{E}+6$ & $4.57 \mathrm{E}+6$ & $6.41 \mathrm{E}+7$ & $1.55 \mathrm{E}+5$ \\
\hline 074-S1-RS09 & $\mathrm{M} / \mathrm{A}$ & $1.12 \mathrm{E}+0$ & $1.15 \mathrm{E}+0$ & $1.10 \mathrm{E}+0$ & $1.12 \mathrm{E}+0$ & $1.11 \mathrm{E}+0$ & $1.06 \mathrm{E}+0$ \\
\hline 074-S1-RS09 & M/AA & $9.97 \mathrm{E}-1$ & $1.02 \mathrm{E}+0$ & $9.81 \mathrm{E}-1$ & $1.00 \mathrm{E}+0$ & $9.88 \mathrm{E}-1$ & $9.49 \mathrm{E}-1$ \\
\hline 074-S1-RS09 & $\mathrm{M} / \mathrm{C}$ & $1.10 \mathrm{E}+0$ & $6.91 \mathrm{E}-1$ & $9.59 \mathrm{E}-1$ & $1.04 \mathrm{E}+0$ & $9.86 \mathrm{E}-1$ & $8.70 \mathrm{E}-1$ \\
\hline
\end{tabular}


Appendix Table B-1 continued. Radionuclide inventories of particles from AGR-3/4 Compact 7-4

\begin{tabular}{|c|c|c|c|c|c|c|c|}
\hline Particle & Value & ${ }^{106} \mathbf{R u}$ & ${ }^{125} \mathrm{Sb}$ & ${ }^{134} \mathrm{Cs}$ & ${ }^{137} \mathrm{Cs}$ & ${ }^{144} \mathrm{Ce}$ & ${ }^{154} \mathbf{E u}$ \\
\hline 074-S1-RS10 & $\mathrm{Bq}$ & $1.44 \mathrm{E}+7$ & $1.93 \mathrm{E}+5$ & $4.43 E+6$ & $3.67 \mathrm{E}+6$ & $5.22 \mathrm{E}+7$ & $1.35 \mathrm{E}+5$ \\
\hline 074-S1-RS10 & $\mathrm{M} / \mathrm{A}$ & $9.38 \mathrm{E}-1$ & $9.18 \mathrm{E}-1$ & $8.82 \mathrm{E}-1$ & $9.01 \mathrm{E}-1$ & $9.03 \mathrm{E}-1$ & $9.24 \mathrm{E}-1$ \\
\hline 074-S1-RS10 & $\mathrm{M} / \mathrm{AA}$ & $1.04 \mathrm{E}+0$ & $1.02 \mathrm{E}+0$ & $9.79 \mathrm{E}-1$ & $1.00 \mathrm{E}+0$ & $1.00 \mathrm{E}+0$ & $1.03 \mathrm{E}+0$ \\
\hline 074-S1-RS10 & $\mathrm{M} / \mathrm{C}$ & $1.15 \mathrm{E}+0$ & $6.88 \mathrm{E}-1$ & $9.57 \mathrm{E}-1$ & $1.04 \mathrm{E}+0$ & $9.99 \mathrm{E}-1$ & $9.41 \mathrm{E}-1$ \\
\hline 074-S1-RS11 & $\mathrm{Bq}$ & $1.67 \mathrm{E}+7$ & $2.14 \mathrm{E}+5$ & $5.27 \mathrm{E}+6$ & $4.20 \mathrm{E}+6$ & $6.03 \mathrm{E}+7$ & $1.51 \mathrm{E}+5$ \\
\hline 074-S1-RS11 & $\mathrm{M} / \mathrm{A}$ & $1.09 \mathrm{E}+0$ & $1.02 \mathrm{E}+0$ & $1.05 \mathrm{E}+0$ & $1.03 \mathrm{E}+0$ & $1.04 \mathrm{E}+0$ & $1.03 \mathrm{E}+0$ \\
\hline 074-S1-RS11 & $\mathrm{M} / \mathrm{AA}$ & $1.06 \mathrm{E}+0$ & $9.88 \mathrm{E}-1$ & $1.02 \mathrm{E}+0$ & $1.00 \mathrm{E}+0$ & $1.01 \mathrm{E}+0$ & $1.00 \mathrm{E}+0$ \\
\hline 074-S1-RS11 & $\mathrm{M} / \mathrm{C}$ & $1.17 \mathrm{E}+0$ & $6.67 \mathrm{E}-1$ & $9.95 \mathrm{E}-1$ & $1.04 \mathrm{E}+0$ & $1.01 \mathrm{E}+0$ & $9.21 \mathrm{E}-1$ \\
\hline 074-S1-RS12 & $\mathrm{Bq}$ & $1.77 \mathrm{E}+7$ & $2.42 \mathrm{E}+5$ & $5.30 \mathrm{E}+6$ & $4.37 \mathrm{E}+6$ & $6.07 \mathrm{E}+7$ & $1.45 \mathrm{E}+5$ \\
\hline 074-S1-RS12 & $\mathrm{M} / \mathrm{A}$ & $1.16 \mathrm{E}+0$ & $1.15 \mathrm{E}+0$ & $1.05 \mathrm{E}+0$ & $1.07 \mathrm{E}+0$ & $1.05 \mathrm{E}+0$ & $9.93 \mathrm{E}-1$ \\
\hline 074-S1-RS12 & $\mathrm{M} / \mathrm{AA}$ & $1.08 \mathrm{E}+0$ & $1.07 \mathrm{E}+0$ & $9.83 \mathrm{E}-1$ & $1.00 \mathrm{E}+0$ & $9.79 \mathrm{E}-1$ & $9.26 \mathrm{E}-1$ \\
\hline 074-S1-RS12 & $\mathrm{M} / \mathrm{C}$ & $1.19 \mathrm{E}+0$ & $7.26 \mathrm{E}-1$ & $9.61 \mathrm{E}-1$ & $1.04 \mathrm{E}+0$ & $9.77 \mathrm{E}-1$ & $8.49 \mathrm{E}-1$ \\
\hline 074-S1-RS13 & $\mathrm{Bq}$ & $1.40 \mathrm{E}+7$ & $1.81 \mathrm{E}+5$ & $4.33 \mathrm{E}+6$ & $3.50 \mathrm{E}+6$ & $4.77 \mathrm{E}+7$ & $1.29 \mathrm{E}+5$ \\
\hline 074-S1-RS13 & $\mathrm{M} / \mathrm{A}$ & $9.14 \mathrm{E}-1$ & $8.61 \mathrm{E}-1$ & $8.60 \mathrm{E}-1$ & $8.58 \mathrm{E}-1$ & $8.25 \mathrm{E}-1$ & $8.85 \mathrm{E}-1$ \\
\hline 074-S1-RS13 & $\mathrm{M} / \mathrm{AA}$ & $1.07 \mathrm{E}+0$ & $1.00 \mathrm{E}+0$ & $1.00 \mathrm{E}+0$ & $1.00 \mathrm{E}+0$ & $9.62 \mathrm{E}-1$ & $1.03 \mathrm{E}+0$ \\
\hline 074-S1-RS13 & $\mathrm{M} / \mathrm{C}$ & $1.18 \mathrm{E}+0$ & $6.77 \mathrm{E}-1$ & $9.80 \mathrm{E}-1$ & $1.04 \mathrm{E}+0$ & $9.59 \mathrm{E}-1$ & $9.46 \mathrm{E}-1$ \\
\hline 074-S1-RS14 & $\mathrm{Bq}$ & $1.66 \mathrm{E}+7$ & $2.28 \mathrm{E}+5$ & $5.24 \mathrm{E}+6$ & $4.17 \mathrm{E}+6$ & $5.79 \mathrm{E}+7$ & $1.54 \mathrm{E}+5$ \\
\hline 074-S1-RS14 & $\mathrm{M} / \mathrm{A}$ & $1.08 \mathrm{E}+0$ & $1.08 \mathrm{E}+0$ & $1.04 \mathrm{E}+0$ & $1.02 \mathrm{E}+0$ & $1.00 \mathrm{E}+0$ & $1.06 \mathrm{E}+0$ \\
\hline 074-S1-RS14 & $\mathrm{M} / \mathrm{AA}$ & $1.06 \mathrm{E}+0$ & $1.06 \mathrm{E}+0$ & $1.02 \mathrm{E}+0$ & $1.00 \mathrm{E}+0$ & $9.78 \mathrm{E}-1$ & $1.03 \mathrm{E}+0$ \\
\hline 074-S1-RS14 & $\mathrm{M} / \mathrm{C}$ & $1.17 \mathrm{E}+0$ & $7.15 \mathrm{E}-1$ & $9.95 \mathrm{E}-1$ & $1.04 \mathrm{E}+0$ & $9.76 \mathrm{E}-1$ & $9.47 \mathrm{E}-1$ \\
\hline 074-S1-RS15 & $\mathrm{Bq}$ & $1.53 \mathrm{E}+7$ & $2.14 \mathrm{E}+5$ & $4.74 \mathrm{E}+6$ & $3.92 \mathrm{E}+6$ & $5.47 \mathrm{E}+7$ & $1.44 \mathrm{E}+5$ \\
\hline 074-S1-RS15 & $\mathrm{M} / \mathrm{A}$ & $9.99 \mathrm{E}-1$ & $1.02 \mathrm{E}+0$ & $9.43 \mathrm{E}-1$ & $9.61 \mathrm{E}-1$ & $9.45 \mathrm{E}-1$ & $9.86 \mathrm{E}-1$ \\
\hline 074-S1-RS15 & $\mathrm{M} / \mathrm{AA}$ & $1.04 \mathrm{E}+0$ & $1.06 \mathrm{E}+0$ & $9.81 \mathrm{E}-1$ & $1.00 \mathrm{E}+0$ & $9.83 \mathrm{E}-1$ & $1.03 \mathrm{E}+0$ \\
\hline 074-S1-RS15 & $\mathrm{M} / \mathrm{C}$ & $1.15 \mathrm{E}+0$ & $7.13 \mathrm{E}-1$ & $9.60 \mathrm{E}-1$ & $1.04 \mathrm{E}+0$ & $9.81 \mathrm{E}-1$ & $9.41 \mathrm{E}-1$ \\
\hline 074-S2-RS01 & $\mathrm{Bq}$ & $1.37 \mathrm{E}+7$ & $1.82 \mathrm{E}+5$ & $4.49 E+6$ & $3.57 \mathrm{E}+6$ & $5.32 \mathrm{E}+7$ & $1.34 \mathrm{E}+5$ \\
\hline 074-S2-RS01 & $\mathrm{M} / \mathrm{A}$ & $8.92 \mathrm{E}-1$ & $8.66 \mathrm{E}-1$ & $8.94 \mathrm{E}-1$ & $8.76 \mathrm{E}-1$ & $9.19 \mathrm{E}-1$ & $9.22 \mathrm{E}-1$ \\
\hline 074-S2-RS01 & $\mathrm{M} / \mathrm{AA}$ & $1.02 \mathrm{E}+0$ & $9.89 \mathrm{E}-1$ & $1.02 \mathrm{E}+0$ & $1.00 \mathrm{E}+0$ & $1.05 \mathrm{E}+0$ & $1.05 \mathrm{E}+0$ \\
\hline 074-S2-RS01 & $\mathrm{M} / \mathrm{C}$ & $1.13 \mathrm{E}+0$ & $6.67 \mathrm{E}-1$ & $9.97 \mathrm{E}-1$ & $1.04 \mathrm{E}+0$ & $1.05 \mathrm{E}+0$ & $9.65 \mathrm{E}-1$ \\
\hline 074-S2-RS02 & $\mathrm{Bq}$ & $1.62 \mathrm{E}+7$ & $2.09 \mathrm{E}+5$ & $5.38 \mathrm{E}+6$ & $4.27 \mathrm{E}+6$ & $6.28 \mathrm{E}+7$ & $1.57 \mathrm{E}+5$ \\
\hline 074-S2-RS02 & $\mathrm{M} / \mathrm{A}$ & $1.06 \mathrm{E}+0$ & $9.93 \mathrm{E}-1$ & $1.07 \mathrm{E}+0$ & $1.05 \mathrm{E}+0$ & $1.09 \mathrm{E}+0$ & $1.08 \mathrm{E}+0$ \\
\hline 074-S2-RS02 & $\mathrm{M} / \mathrm{AA}$ & $1.01 \mathrm{E}+0$ & $9.49 \mathrm{E}-1$ & $1.02 \mathrm{E}+0$ & $1.00 \mathrm{E}+0$ & $1.04 \mathrm{E}+0$ & $1.03 \mathrm{E}+0$ \\
\hline 074-S2-RS02 & $\mathrm{M} / \mathrm{C}$ & $1.12 \mathrm{E}+0$ & $6.41 \mathrm{E}-1$ & $1.00 \mathrm{E}+0$ & $1.04 \mathrm{E}+0$ & $1.04 \mathrm{E}+0$ & $9.43 \mathrm{E}-1$ \\
\hline 074-S2-RS03 & $\mathrm{Bq}$ & $1.57 \mathrm{E}+7$ & $1.99 \mathrm{E}+5$ & $5.13 \mathrm{E}+6$ & $4.12 \mathrm{E}+6$ & $6.14 \mathrm{E}+7$ & $1.53 \mathrm{E}+5$ \\
\hline 074-S2-RS03 & $\mathrm{M} / \mathrm{A}$ & $1.02 \mathrm{E}+0$ & $9.45 \mathrm{E}-1$ & $1.02 \mathrm{E}+0$ & $1.01 \mathrm{E}+0$ & $1.06 \mathrm{E}+0$ & $1.05 \mathrm{E}+0$ \\
\hline 074-S2-RS03 & $\mathrm{M} / \mathrm{AA}$ & $1.01 \mathrm{E}+0$ & $9.34 \mathrm{E}-1$ & $1.01 \mathrm{E}+0$ & $1.00 \mathrm{E}+0$ & $1.05 \mathrm{E}+0$ & $1.04 \mathrm{E}+0$ \\
\hline 074-S2-RS03 & $\mathrm{M} / \mathrm{C}$ & $1.12 \mathrm{E}+0$ & $6.31 \mathrm{E}-1$ & $9.86 \mathrm{E}-1$ & $1.04 \mathrm{E}+0$ & $1.05 \mathrm{E}+0$ & $9.50 \mathrm{E}-1$ \\
\hline 074-S2-RS04 & $\mathrm{Bq}$ & $1.51 \mathrm{E}+7$ & $2.11 \mathrm{E}+5$ & $5.13 E+6$ & $4.05 \mathrm{E}+6$ & $5.77 \mathrm{E}+7$ & $1.49 \mathrm{E}+5$ \\
\hline 074-S2-RS04 & $\mathrm{M} / \mathrm{A}$ & $9.84 \mathrm{E}-1$ & $1.00 \mathrm{E}+0$ & $1.02 \mathrm{E}+0$ & $9.93 \mathrm{E}-1$ & $9.97 \mathrm{E}-1$ & $1.02 \mathrm{E}+0$ \\
\hline 074-S2-RS04 & $\mathrm{M} / \mathrm{AA}$ & $9.90 \mathrm{E}-1$ & $1.01 \mathrm{E}+0$ & $1.03 \mathrm{E}+0$ & $1.00 \mathrm{E}+0$ & $1.00 \mathrm{E}+0$ & $1.03 \mathrm{E}+0$ \\
\hline 074-S2-RS04 & $\mathrm{M} / \mathrm{C}$ & $1.10 \mathrm{E}+0$ & $6.80 \mathrm{E}-1$ & $1.00 \mathrm{E}+0$ & $1.04 \mathrm{E}+0$ & $1.00 \mathrm{E}+0$ & $9.41 \mathrm{E}-1$ \\
\hline 074-S2-RS05 & $\mathrm{Bq}$ & $1.37 \mathrm{E}+7$ & $1.99 \mathrm{E}+5$ & $4.41 \mathrm{E}+6$ & $3.67 \mathrm{E}+6$ & $5.14 \mathrm{E}+7$ & $1.35 \mathrm{E}+5$ \\
\hline 074-S2-RS05 & $\mathrm{M} / \mathrm{A}$ & $8.94 \mathrm{E}-1$ & $9.46 \mathrm{E}-1$ & $8.76 \mathrm{E}-1$ & $9.00 \mathrm{E}-1$ & $8.88 \mathrm{E}-1$ & $9.28 \mathrm{E}-1$ \\
\hline 074-S2-RS05 & $\mathrm{M} / \mathrm{AA}$ & $9.94 \mathrm{E}-1$ & $1.05 \mathrm{E}+0$ & $9.74 \mathrm{E}-1$ & $1.00 \mathrm{E}+0$ & $9.87 \mathrm{E}-1$ & $1.03 \mathrm{E}+0$ \\
\hline 074-S2-RS05 & $\mathrm{M} / \mathrm{C}$ & $1.10 \mathrm{E}+0$ & $7.10 \mathrm{E}-1$ & $9.52 \mathrm{E}-1$ & $1.04 \mathrm{E}+0$ & $9.85 \mathrm{E}-1$ & $9.45 \mathrm{E}-1$ \\
\hline 074-S2-RS06 & $\mathrm{Bq}$ & $1.45 \mathrm{E}+7$ & $1.93 \mathrm{E}+5$ & $4.83 \mathrm{E}+6$ & $3.84 \mathrm{E}+6$ & $5.85 \mathrm{E}+7$ & $1.40 \mathrm{E}+5$ \\
\hline 074-S2-RS06 & $\mathrm{M} / \mathrm{A}$ & $9.47 \mathrm{E}-1$ & $9.15 \mathrm{E}-1$ & $9.61 \mathrm{E}-1$ & $9.41 \mathrm{E}-1$ & $1.01 \mathrm{E}+0$ & $9.61 \mathrm{E}-1$ \\
\hline 074-S2-RS06 & $\mathrm{M} / \mathrm{AA}$ & $1.01 \mathrm{E}+0$ & $9.72 \mathrm{E}-1$ & $1.02 \mathrm{E}+0$ & $1.00 \mathrm{E}+0$ & $1.07 \mathrm{E}+0$ & $1.02 \mathrm{E}+0$ \\
\hline 074-S2-RS06 & $\mathrm{M} / \mathrm{C}$ & $1.11 \mathrm{E}+0$ & $6.56 \mathrm{E}-1$ & $9.98 \mathrm{E}-1$ & $1.04 \mathrm{E}+0$ & $1.07 \mathrm{E}+0$ & $9.36 \mathrm{E}-1$ \\
\hline
\end{tabular}


Appendix Table B-1 continued. Radionuclide inventories of particles from AGR-3/4 Compact 7-4

\begin{tabular}{|c|c|c|c|c|c|c|c|}
\hline Particle & Value & ${ }^{106} \mathbf{R u}$ & ${ }^{125} \mathrm{Sb}$ & ${ }^{134} \mathrm{Cs}$ & ${ }^{137} \mathrm{Cs}$ & ${ }^{144} \mathrm{Ce}$ & ${ }^{154} \mathbf{E u}$ \\
\hline 074-S2-RS07 & $\mathrm{Bq}$ & $1.63 \mathrm{E}+7$ & $2.23 \mathrm{E}+5$ & $5.52 \mathrm{E}+6$ & $4.36 \mathrm{E}+6$ & $5.84 \mathrm{E}+7$ & $1.04 \mathrm{E}+5$ \\
\hline 074-S2-RS07 & $\mathrm{M} / \mathrm{A}$ & $1.06 \mathrm{E}+0$ & $1.06 \mathrm{E}+0$ & $1.10 \mathrm{E}+0$ & $1.07 \mathrm{E}+0$ & $1.01 \mathrm{E}+0$ & $7.16 \mathrm{E}-1$ \\
\hline 074-S2-RS07 & $\mathrm{M} / \mathrm{AA}$ & 9.93E-1 & $9.88 \mathrm{E}-1$ & $1.03 \mathrm{E}+0$ & $1.00 \mathrm{E}+0$ & $9.44 \mathrm{E}-1$ & $6.70 \mathrm{E}-1$ \\
\hline 074-S2-RS07 & $\mathrm{M} / \mathrm{C}$ & $1.10 \mathrm{E}+0$ & $6.67 \mathrm{E}-1$ & $1.00 \mathrm{E}+0$ & $1.04 \mathrm{E}+0$ & $9.42 \mathrm{E}-1$ & $6.14 \mathrm{E}-1$ \\
\hline 074-S2-RS08 & $\mathrm{Bq}$ & $1.57 \mathrm{E}+7$ & $2.20 \mathrm{E}+5$ & $5.20 \mathrm{E}+6$ & $4.30 \mathrm{E}+6$ & $6.05 \mathrm{E}+7$ & $1.55 \mathrm{E}+5$ \\
\hline 074-S2-RS08 & $\mathrm{M} / \mathrm{A}$ & $1.02 \mathrm{E}+0$ & $1.05 \mathrm{E}+0$ & $1.03 \mathrm{E}+0$ & $1.06 \mathrm{E}+0$ & $1.05 \mathrm{E}+0$ & $1.07 \mathrm{E}+0$ \\
\hline 074-S2-RS08 & $\mathrm{M} / \mathrm{AA}$ & $9.68 \mathrm{E}-1$ & $9.90 \mathrm{E}-1$ & $9.79 \mathrm{E}-1$ & $1.00 \mathrm{E}+0$ & $9.91 \mathrm{E}-1$ & $1.01 \mathrm{E}+0$ \\
\hline 074-S2-RS08 & $\mathrm{M} / \mathrm{C}$ & $1.07 \mathrm{E}+0$ & $6.69 \mathrm{E}-1$ & $9.58 \mathrm{E}-1$ & $1.04 \mathrm{E}+0$ & $9.88 \mathrm{E}-1$ & $9.25 \mathrm{E}-1$ \\
\hline 074-S2-RS09 & $\mathrm{Bq}$ & $1.47 \mathrm{E}+7$ & $1.94 \mathrm{E}+5$ & $4.62 \mathrm{E}+6$ & $3.85 \mathrm{E}+6$ & $5.28 \mathrm{E}+7$ & $1.42 \mathrm{E}+5$ \\
\hline 074-S2-RS09 & $\mathrm{M} / \mathrm{A}$ & $9.57 \mathrm{E}-1$ & $9.22 \mathrm{E}-1$ & $9.18 \mathrm{E}-1$ & $9.46 \mathrm{E}-1$ & $9.13 \mathrm{E}-1$ & $9.75 \mathrm{E}-1$ \\
\hline 074-S2-RS09 & $\mathrm{M} / \mathrm{AA}$ & $1.01 \mathrm{E}+0$ & $9.75 \mathrm{E}-1$ & $9.70 \mathrm{E}-1$ & $1.00 \mathrm{E}+0$ & $9.66 \mathrm{E}-1$ & $1.03 \mathrm{E}+0$ \\
\hline 074-S2-RS09 & $\mathrm{M} / \mathrm{C}$ & $1.12 \mathrm{E}+0$ & $6.58 \mathrm{E}-1$ & $9.49 \mathrm{E}-1$ & $1.04 \mathrm{E}+0$ & $9.63 \mathrm{E}-1$ & $9.45 \mathrm{E}-1$ \\
\hline 074-S2-RS10 & $\mathrm{Bq}$ & $1.41 \mathrm{E}+7$ & $1.93 \mathrm{E}+5$ & $4.81 \mathrm{E}+6$ & $3.86 \mathrm{E}+6$ & $5.40 \mathrm{E}+7$ & $1.40 \mathrm{E}+5$ \\
\hline 074-S2-RS10 & $\mathrm{M} / \mathrm{A}$ & $9.23 \mathrm{E}-1$ & $9.16 \mathrm{E}-1$ & $9.57 \mathrm{E}-1$ & $9.47 \mathrm{E}-1$ & $9.33 \mathrm{E}-1$ & $9.62 \mathrm{E}-1$ \\
\hline 074-S2-RS10 & $\mathrm{M} / \mathrm{AA}$ & $9.75 \mathrm{E}-1$ & $9.67 \mathrm{E}-1$ & $1.01 \mathrm{E}+0$ & $1.00 \mathrm{E}+0$ & $9.85 \mathrm{E}-1$ & $1.02 \mathrm{E}+0$ \\
\hline 074-S2-RS10 & $\mathrm{M} / \mathrm{C}$ & $1.08 \mathrm{E}+0$ & $6.53 \mathrm{E}-1$ & $9.88 \mathrm{E}-1$ & $1.04 \mathrm{E}+0$ & $9.83 \mathrm{E}-1$ & $9.31 \mathrm{E}-1$ \\
\hline 074-S2-RS1 1 & $\mathrm{~Bq}$ & $1.40 \mathrm{E}+7$ & $1.82 \mathrm{E}+5$ & $4.65 E+6$ & $3.74 \mathrm{E}+6$ & $5.25 \mathrm{E}+7$ & $1.38 \mathrm{E}+5$ \\
\hline 074-S2-RS11 & $\mathrm{M} / \mathrm{A}$ & $9.11 \mathrm{E}-1$ & $8.63 \mathrm{E}-1$ & $9.24 \mathrm{E}-1$ & $9.19 \mathrm{E}-1$ & $9.07 \mathrm{E}-1$ & $9.46 \mathrm{E}-1$ \\
\hline 074-S2-RS11 & $\mathrm{M} / \mathrm{AA}$ & $9.91 \mathrm{E}-1$ & 9.39E-1 & $1.01 \mathrm{E}+0$ & $1.00 \mathrm{E}+0$ & $9.87 \mathrm{E}-1$ & $1.03 \mathrm{E}+0$ \\
\hline 074-S2-RS11 & $\mathrm{M} / \mathrm{C}$ & $1.10 \mathrm{E}+0$ & $6.34 \mathrm{E}-1$ & $9.83 \mathrm{E}-1$ & $1.04 \mathrm{E}+0$ & $9.84 \mathrm{E}-1$ & $9.43 \mathrm{E}-1$ \\
\hline 074-S2-RS12 & $\mathrm{Bq}$ & $1.51 \mathrm{E}+7$ & $2.14 \mathrm{E}+5$ & $5.12 \mathrm{E}+6$ & $4.11 \mathrm{E}+6$ & $5.87 \mathrm{E}+7$ & $1.45 \mathrm{E}+5$ \\
\hline 074-S2-RS12 & $\mathrm{M} / \mathrm{A}$ & $9.82 \mathrm{E}-1$ & $1.01 \mathrm{E}+0$ & $1.02 \mathrm{E}+0$ & $1.01 \mathrm{E}+0$ & $1.01 \mathrm{E}+0$ & $9.96 \mathrm{E}-1$ \\
\hline 074-S2-RS12 & $\mathrm{M} / \mathrm{AA}$ & $9.73 \mathrm{E}-1$ & $1.01 \mathrm{E}+0$ & $1.01 \mathrm{E}+0$ & $1.00 \mathrm{E}+0$ & $1.01 \mathrm{E}+0$ & $9.87 \mathrm{E}-1$ \\
\hline 074-S2-RS12 & $\mathrm{M} / \mathrm{C}$ & $1.08 \mathrm{E}+0$ & $6.79 \mathrm{E}-1$ & $9.87 \mathrm{E}-1$ & $1.04 \mathrm{E}+0$ & $1.00 \mathrm{E}+0$ & $9.05 \mathrm{E}-1$ \\
\hline 074-S2-RS13 & $\mathrm{Bq}$ & $1.46 \mathrm{E}+7$ & $2.02 \mathrm{E}+5$ & $4.95 \mathrm{E}+6$ & $4.03 \mathrm{E}+6$ & $5.47 \mathrm{E}+7$ & $1.47 \mathrm{E}+5$ \\
\hline 074-S2-RS13 & $\mathrm{M} / \mathrm{A}$ & $9.53 \mathrm{E}-1$ & $9.62 \mathrm{E}-1$ & $9.85 \mathrm{E}-1$ & $9.89 \mathrm{E}-1$ & $9.45 \mathrm{E}-1$ & $1.01 \mathrm{E}+0$ \\
\hline 074-S2-RS13 & $\mathrm{M} / \mathrm{AA}$ & $9.64 \mathrm{E}-1$ & $9.72 \mathrm{E}-1$ & $9.95 \mathrm{E}-1$ & $1.00 \mathrm{E}+0$ & $9.55 \mathrm{E}-1$ & $1.02 \mathrm{E}+0$ \\
\hline 074-S2-RS13 & $\mathrm{M} / \mathrm{C}$ & $1.07 \mathrm{E}+0$ & $6.56 \mathrm{E}-1$ & $9.73 \mathrm{E}-1$ & $1.04 \mathrm{E}+0$ & $9.53 \mathrm{E}-1$ & $9.34 \mathrm{E}-1$ \\
\hline 074-S2-RS14 & $\mathrm{Bq}$ & $1.52 \mathrm{E}+7$ & $2.29 \mathrm{E}+5$ & $5.32 \mathrm{E}+6$ & $4.24 \mathrm{E}+6$ & $5.62 \mathrm{E}+7$ & $1.53 \mathrm{E}+5$ \\
\hline 074-S2-RS14 & $\mathrm{M} / \mathrm{A}$ & $9.90 \mathrm{E}-1$ & $1.09 \mathrm{E}+0$ & $1.06 \mathrm{E}+0$ & $1.04 \mathrm{E}+0$ & $9.72 \mathrm{E}-1$ & $1.05 \mathrm{E}+0$ \\
\hline 074-S2-RS14 & $\mathrm{M} / \mathrm{AA}$ & $9.50 \mathrm{E}-1$ & $1.05 \mathrm{E}+0$ & $1.02 \mathrm{E}+0$ & $1.00 \mathrm{E}+0$ & $9.33 \mathrm{E}-1$ & $1.01 \mathrm{E}+0$ \\
\hline 074-S2-RS14 & $\mathrm{M} / \mathrm{C}$ & $1.05 \mathrm{E}+0$ & $7.06 \mathrm{E}-1$ & $9.93 \mathrm{E}-1$ & $1.04 \mathrm{E}+0$ & $9.31 \mathrm{E}-1$ & $9.25 \mathrm{E}-1$ \\
\hline 074-S2-RS15 & $\mathrm{Bq}$ & $1.65 \mathrm{E}+7$ & $2.25 \mathrm{E}+5$ & $5.49 \mathrm{E}+6$ & $4.40 \mathrm{E}+6$ & $6.44 \mathrm{E}+7$ & $1.52 \mathrm{E}+5$ \\
\hline 074-S2-RS15 & $\mathrm{M} / \mathrm{A}$ & $1.08 \mathrm{E}+0$ & $1.07 \mathrm{E}+0$ & $1.09 \mathrm{E}+0$ & $1.08 \mathrm{E}+0$ & $1.11 \mathrm{E}+0$ & $1.05 \mathrm{E}+0$ \\
\hline 074-S2-RS15 & $\mathrm{M} / \mathrm{AA}$ & $1.00 \mathrm{E}+0$ & $9.90 \mathrm{E}-1$ & $1.01 \mathrm{E}+0$ & $1.00 \mathrm{E}+0$ & $1.03 \mathrm{E}+0$ & $9.70 \mathrm{E}-1$ \\
\hline 074-S2-RS15 & $\mathrm{M} / \mathrm{C}$ & $1.11 \mathrm{E}+0$ & $6.69 \mathrm{E}-1$ & $9.89 \mathrm{E}-1$ & $1.04 \mathrm{E}+0$ & $1.03 \mathrm{E}+0$ & 8.89E-1 \\
\hline 074-S3-RS01 & $\mathrm{Bq}$ & $1.36 \mathrm{E}+7$ & $2.11 \mathrm{E}+5$ & $4.71 \mathrm{E}+6$ & $3.74 \mathrm{E}+6$ & $5.36 \mathrm{E}+7$ & $1.36 \mathrm{E}+5$ \\
\hline 074-S3-RS01 & $\mathrm{M} / \mathrm{A}$ & $8.85 \mathrm{E}-1$ & $1.00 \mathrm{E}+0$ & $9.37 \mathrm{E}-1$ & $9.19 \mathrm{E}-1$ & $9.27 \mathrm{E}-1$ & $9.32 \mathrm{E}-1$ \\
\hline 074-S3-RS01 & $\mathrm{M} / \mathrm{AA}$ & $9.63 \mathrm{E}-1$ & $1.09 \mathrm{E}+0$ & $1.02 \mathrm{E}+0$ & $1.00 \mathrm{E}+0$ & $1.01 \mathrm{E}+0$ & $1.01 \mathrm{E}+0$ \\
\hline 074-S3-RS01 & $\mathrm{M} / \mathrm{C}$ & $1.07 \mathrm{E}+0$ & $7.35 \mathrm{E}-1$ & $9.96 \mathrm{E}-1$ & $1.04 \mathrm{E}+0$ & $1.01 \mathrm{E}+0$ & 9.30E-1 \\
\hline 074-S3-RS02 & $\mathrm{Bq}$ & $1.50 \mathrm{E}+7$ & $2.11 \mathrm{E}+5$ & $4.75 \mathrm{E}+6$ & $3.90 \mathrm{E}+6$ & $5.64 \mathrm{E}+7$ & $1.44 \mathrm{E}+5$ \\
\hline 074-S3-RS02 & $\mathrm{M} / \mathrm{A}$ & $9.78 \mathrm{E}-1$ & $1.00 \mathrm{E}+0$ & $9.44 \mathrm{E}-1$ & $9.57 \mathrm{E}-1$ & $9.76 \mathrm{E}-1$ & $9.92 \mathrm{E}-1$ \\
\hline 074-S3-RS02 & $\mathrm{M} / \mathrm{AA}$ & $1.02 \mathrm{E}+0$ & $1.05 \mathrm{E}+0$ & $9.86 \mathrm{E}-1$ & $1.00 \mathrm{E}+0$ & $1.02 \mathrm{E}+0$ & $1.04 \mathrm{E}+0$ \\
\hline 074-S3-RS02 & $\mathrm{M} / \mathrm{C}$ & $1.13 \mathrm{E}+0$ & $7.08 \mathrm{E}-1$ & $9.64 \mathrm{E}-1$ & $1.04 \mathrm{E}+0$ & $1.02 \mathrm{E}+0$ & $9.50 \mathrm{E}-1$ \\
\hline 074-S3-RS03 & $\mathrm{Bq}$ & $1.44 \mathrm{E}+7$ & $2.14 \mathrm{E}+5$ & $4.91 \mathrm{E}+6$ & $4.01 \mathrm{E}+6$ & $5.69 \mathrm{E}+7$ & $1.47 \mathrm{E}+5$ \\
\hline 074-S3-RS03 & $\mathrm{M} / \mathrm{A}$ & $9.37 \mathrm{E}-1$ & $1.02 \mathrm{E}+0$ & $9.77 \mathrm{E}-1$ & $9.84 \mathrm{E}-1$ & $9.84 \mathrm{E}-1$ & $1.01 \mathrm{E}+0$ \\
\hline 074-S3-RS03 & $\mathrm{M} / \mathrm{AA}$ & $9.53 \mathrm{E}-1$ & $1.03 \mathrm{E}+0$ & $9.93 \mathrm{E}-1$ & $1.00 \mathrm{E}+0$ & $1.00 \mathrm{E}+0$ & $1.03 \mathrm{E}+0$ \\
\hline 074-S3-RS03 & $\mathrm{M} / \mathrm{C}$ & $1.05 \mathrm{E}+0$ & $6.98 \mathrm{E}-1$ & $9.71 \mathrm{E}-1$ & $1.04 \mathrm{E}+0$ & $9.98 \mathrm{E}-1$ & $9.42 \mathrm{E}-1$ \\
\hline
\end{tabular}


Appendix Table B-1 continued. Radionuclide inventories of particles from AGR-3/4 Compact 7-4

\begin{tabular}{|c|c|c|c|c|c|c|c|}
\hline Particle & Value & ${ }^{106} \mathbf{R u}$ & ${ }^{125} \mathrm{Sb}$ & ${ }^{134} \mathrm{Cs}$ & ${ }^{137} \mathrm{Cs}$ & ${ }^{144} \mathrm{Ce}$ & ${ }^{154} \mathbf{E u}$ \\
\hline 074-S3-RS04 & $\mathrm{Bq}$ & $1.49 \mathrm{E}+7$ & $2.08 \mathrm{E}+5$ & $5.13 \mathrm{E}+6$ & $4.11 \mathrm{E}+6$ & $6.00 \mathrm{E}+7$ & $1.51 \mathrm{E}+5$ \\
\hline 074-S3-RS04 & $\mathrm{M} / \mathrm{A}$ & $9.75 \mathrm{E}-1$ & $9.90 \mathrm{E}-1$ & $1.02 \mathrm{E}+0$ & $1.01 \mathrm{E}+0$ & $1.04 \mathrm{E}+0$ & $1.03 \mathrm{E}+0$ \\
\hline 074-S3-RS04 & $\mathrm{M} / \mathrm{AA}$ & $9.67 \mathrm{E}-1$ & $9.82 \mathrm{E}-1$ & $1.01 \mathrm{E}+0$ & $1.00 \mathrm{E}+0$ & $1.03 \mathrm{E}+0$ & $1.03 \mathrm{E}+0$ \\
\hline 074-S3-RS04 & $\mathrm{M} / \mathrm{C}$ & $1.07 \mathrm{E}+0$ & $6.63 \mathrm{E}-1$ & $9.89 \mathrm{E}-1$ & $1.04 \mathrm{E}+0$ & $1.03 \mathrm{E}+0$ & $9.40 \mathrm{E}-1$ \\
\hline 074-S3-RS05 & $\mathrm{Bq}$ & $1.54 \mathrm{E}+7$ & $2.05 \mathrm{E}+5$ & $5.34 \mathrm{E}+6$ & $4.27 \mathrm{E}+6$ & $6.38 \mathrm{E}+7$ & $1.56 \mathrm{E}+5$ \\
\hline 074-S3-RS05 & $\mathrm{M} / \mathrm{A}$ & $1.01 \mathrm{E}+0$ & $9.73 \mathrm{E}-1$ & $1.06 \mathrm{E}+0$ & $1.05 \mathrm{E}+0$ & $1.10 \mathrm{E}+0$ & $1.07 \mathrm{E}+0$ \\
\hline 074-S3-RS05 & $\mathrm{M} / \mathrm{AA}$ & $9.61 \mathrm{E}-1$ & $9.29 \mathrm{E}-1$ & $1.01 \mathrm{E}+0$ & $1.00 \mathrm{E}+0$ & $1.05 \mathrm{E}+0$ & $1.02 \mathrm{E}+0$ \\
\hline 074-S3-RS05 & $\mathrm{M} / \mathrm{C}$ & $1.06 \mathrm{E}+0$ & $6.27 \mathrm{E}-1$ & $9.91 \mathrm{E}-1$ & $1.04 \mathrm{E}+0$ & $1.05 \mathrm{E}+0$ & $9.36 \mathrm{E}-1$ \\
\hline 074-S3-RS06 & $\mathrm{Bq}$ & $1.62 \mathrm{E}+7$ & $2.27 \mathrm{E}+5$ & $5.36 \mathrm{E}+6$ & $4.44 \mathrm{E}+6$ & $6.21 \mathrm{E}+7$ & $1.38 \mathrm{E}+5$ \\
\hline 074-S3-RS06 & $\mathrm{M} / \mathrm{A}$ & $1.06 \mathrm{E}+0$ & $1.08 \mathrm{E}+0$ & $1.07 \mathrm{E}+0$ & $1.09 \mathrm{E}+0$ & $1.07 \mathrm{E}+0$ & $9.50 \mathrm{E}-1$ \\
\hline 074-S3-RS06 & $\mathrm{M} / \mathrm{AA}$ & $9.72 \mathrm{E}-1$ & $9.89 \mathrm{E}-1$ & $9.78 \mathrm{E}-1$ & $1.00 \mathrm{E}+0$ & $9.86 \mathrm{E}-1$ & $8.72 \mathrm{E}-1$ \\
\hline 074-S3-RS06 & $\mathrm{M} / \mathrm{C}$ & $1.08 \mathrm{E}+0$ & $6.68 \mathrm{E}-1$ & $9.56 \mathrm{E}-1$ & $1.04 \mathrm{E}+0$ & $9.83 \mathrm{E}-1$ & $8.00 \mathrm{E}-1$ \\
\hline 074-S3-RS07 & $\mathrm{Bq}$ & $1.59 \mathrm{E}+7$ & $2.07 \mathrm{E}+5$ & $5.14 \mathrm{E}+6$ & $4.20 \mathrm{E}+6$ & $5.56 \mathrm{E}+7$ & $1.52 \mathrm{E}+5$ \\
\hline 074-S3-RS07 & $\mathrm{M} / \mathrm{A}$ & $1.04 \mathrm{E}+0$ & $9.85 \mathrm{E}-1$ & $1.02 \mathrm{E}+0$ & $1.03 \mathrm{E}+0$ & $9.60 \mathrm{E}-1$ & $1.04 \mathrm{E}+0$ \\
\hline 074-S3-RS07 & $\mathrm{M} / \mathrm{AA}$ & $1.01 \mathrm{E}+0$ & $9.56 \mathrm{E}-1$ & $9.93 \mathrm{E}-1$ & $1.00 \mathrm{E}+0$ & $9.33 \mathrm{E}-1$ & $1.01 \mathrm{E}+0$ \\
\hline 074-S3-RS07 & $\mathrm{M} / \mathrm{C}$ & $1.11 \mathrm{E}+0$ & $6.46 \mathrm{E}-1$ & $9.70 \mathrm{E}-1$ & $1.04 \mathrm{E}+0$ & $9.31 \mathrm{E}-1$ & $9.29 \mathrm{E}-1$ \\
\hline 074-S3-RS08 & $\mathrm{Bq}$ & $1.35 \mathrm{E}+7$ & $1.92 \mathrm{E}+5$ & $4.68 \mathrm{E}+6$ & $3.91 \mathrm{E}+6$ & $5.62 \mathrm{E}+7$ & $1.39 \mathrm{E}+5$ \\
\hline 074-S3-RS08 & $\mathrm{M} / \mathrm{A}$ & $8.82 \mathrm{E}-1$ & $9.12 \mathrm{E}-1$ & $9.30 \mathrm{E}-1$ & $9.59 \mathrm{E}-1$ & $9.72 \mathrm{E}-1$ & $9.55 \mathrm{E}-1$ \\
\hline 074-S3-RS08 & $\mathrm{M} / \mathrm{AA}$ & $9.20 \mathrm{E}-1$ & $9.51 \mathrm{E}-1$ & $9.70 \mathrm{E}-1$ & $1.00 \mathrm{E}+0$ & $1.01 \mathrm{E}+0$ & $9.96 \mathrm{E}-1$ \\
\hline 074-S3-RS08 & $\mathrm{M} / \mathrm{C}$ & $1.02 \mathrm{E}+0$ & $6.42 \mathrm{E}-1$ & $9.48 \mathrm{E}-1$ & $1.04 \mathrm{E}+0$ & $1.01 \mathrm{E}+0$ & $9.13 \mathrm{E}-1$ \\
\hline 074-S3-RS09 & $\mathrm{Bq}$ & $1.33 \mathrm{E}+7$ & $1.93 \mathrm{E}+5$ & $4.53 \mathrm{E}+6$ & $3.64 \mathrm{E}+6$ & $5.33 \mathrm{E}+7$ & $1.34 \mathrm{E}+5$ \\
\hline 074-S3-RS09 & $\mathrm{M} / \mathrm{A}$ & $8.67 \mathrm{E}-1$ & $9.15 \mathrm{E}-1$ & $9.02 \mathrm{E}-1$ & 8.94E-1 & $9.22 \mathrm{E}-1$ & $9.18 \mathrm{E}-1$ \\
\hline 074-S3-RS09 & $\mathrm{M} / \mathrm{AA}$ & $9.70 \mathrm{E}-1$ & $1.02 \mathrm{E}+0$ & $1.01 \mathrm{E}+0$ & $1.00 \mathrm{E}+0$ & $1.03 \mathrm{E}+0$ & $1.03 \mathrm{E}+0$ \\
\hline 074-S3-RS09 & $\mathrm{M} / \mathrm{C}$ & $1.07 \mathrm{E}+0$ & $6.91 \mathrm{E}-1$ & $9.86 \mathrm{E}-1$ & $1.04 \mathrm{E}+0$ & $1.03 \mathrm{E}+0$ & $9.41 \mathrm{E}-1$ \\
\hline 074-S3-RS10 & $\mathrm{Bq}$ & $1.41 \mathrm{E}+7$ & $1.89 \mathrm{E}+5$ & $4.62 \mathrm{E}+6$ & $3.78 \mathrm{E}+6$ & $5.06 \mathrm{E}+7$ & $1.39 \mathrm{E}+5$ \\
\hline 074-S3-RS10 & $\mathrm{M} / \mathrm{A}$ & $9.23 \mathrm{E}-1$ & $8.97 \mathrm{E}-1$ & $9.18 \mathrm{E}-1$ & $9.27 \mathrm{E}-1$ & $8.74 \mathrm{E}-1$ & $9.54 \mathrm{E}-1$ \\
\hline 074-S3-RS10 & $\mathrm{M} / \mathrm{AA}$ & $9.96 \mathrm{E}-1$ & $9.68 \mathrm{E}-1$ & $9.91 \mathrm{E}-1$ & $1.00 \mathrm{E}+0$ & $9.43 \mathrm{E}-1$ & $1.03 \mathrm{E}+0$ \\
\hline 074-S3-RS10 & $\mathrm{M} / \mathrm{C}$ & $1.10 \mathrm{E}+0$ & $6.53 \mathrm{E}-1$ & $9.68 \mathrm{E}-1$ & $1.04 \mathrm{E}+0$ & $9.41 \mathrm{E}-1$ & $9.44 \mathrm{E}-1$ \\
\hline 074-S3-RS11 & $\mathrm{Bq}$ & $1.59 \mathrm{E}+7$ & $2.09 \mathrm{E}+5$ & $5.27 \mathrm{E}+6$ & $4.34 \mathrm{E}+6$ & $6.05 \mathrm{E}+7$ & $1.57 \mathrm{E}+5$ \\
\hline 074-S3-RS11 & $\mathrm{M} / \mathrm{A}$ & $1.04 \mathrm{E}+0$ & $9.94 \mathrm{E}-1$ & $1.05 \mathrm{E}+0$ & $1.06 \mathrm{E}+0$ & $1.05 \mathrm{E}+0$ & $1.07 \mathrm{E}+0$ \\
\hline 074-S3-RS11 & $\mathrm{M} / \mathrm{AA}$ & $9.75 \mathrm{E}-1$ & $9.34 \mathrm{E}-1$ & $9.85 \mathrm{E}-1$ & $1.00 \mathrm{E}+0$ & $9.83 \mathrm{E}-1$ & $1.01 \mathrm{E}+0$ \\
\hline 074-S3-RS11 & $\mathrm{M} / \mathrm{C}$ & $1.08 \mathrm{E}+0$ & $6.31 \mathrm{E}-1$ & $9.63 \mathrm{E}-1$ & $1.04 \mathrm{E}+0$ & $9.80 \mathrm{E}-1$ & $9.26 \mathrm{E}-1$ \\
\hline 074-S3-RS12 & $\mathrm{Bq}$ & $1.53 \mathrm{E}+7$ & $2.01 \mathrm{E}+5$ & $4.83 \mathrm{E}+6$ & $3.92 \mathrm{E}+6$ & $5.50 \mathrm{E}+7$ & $1.40 \mathrm{E}+5$ \\
\hline 074-S3-RS12 & $\mathrm{M} / \mathrm{A}$ & $9.95 \mathrm{E}-1$ & $9.55 \mathrm{E}-1$ & $9.60 \mathrm{E}-1$ & $9.62 \mathrm{E}-1$ & $9.51 \mathrm{E}-1$ & $9.64 \mathrm{E}-1$ \\
\hline 074-S3-RS12 & $\mathrm{M} / \mathrm{AA}$ & $1.03 \mathrm{E}+0$ & $9.93 \mathrm{E}-1$ & $9.99 \mathrm{E}-1$ & $1.00 \mathrm{E}+0$ & $9.89 \mathrm{E}-1$ & $1.00 \mathrm{E}+0$ \\
\hline 074-S3-RS12 & $\mathrm{M} / \mathrm{C}$ & $1.14 \mathrm{E}+0$ & $6.70 \mathrm{E}-1$ & $9.76 \mathrm{E}-1$ & $1.04 \mathrm{E}+0$ & $9.87 \mathrm{E}-1$ & $9.19 \mathrm{E}-1$ \\
\hline 074-S3-RS13 & $\mathrm{Bq}$ & $1.33 \mathrm{E}+7$ & $2.05 \mathrm{E}+5$ & $4.79 \mathrm{E}+6$ & $3.88 \mathrm{E}+6$ & $5.44 \mathrm{E}+7$ & $1.37 \mathrm{E}+5$ \\
\hline 074-S3-RS13 & $\mathrm{M} / \mathrm{A}$ & $8.71 \mathrm{E}-1$ & $9.72 \mathrm{E}-1$ & $9.53 \mathrm{E}-1$ & $9.51 \mathrm{E}-1$ & $9.41 \mathrm{E}-1$ & 9.38E-1 \\
\hline 074-S3-RS13 & $\mathrm{M} / \mathrm{AA}$ & $9.15 \mathrm{E}-1$ & $1.02 \mathrm{E}+0$ & $1.00 \mathrm{E}+0$ & $1.00 \mathrm{E}+0$ & $9.89 \mathrm{E}-1$ & $9.86 \mathrm{E}-1$ \\
\hline 074-S3-RS13 & $\mathrm{M} / \mathrm{C}$ & $1.01 \mathrm{E}+0$ & $6.90 \mathrm{E}-1$ & $9.80 \mathrm{E}-1$ & $1.04 \mathrm{E}+0$ & $9.87 \mathrm{E}-1$ & $9.04 \mathrm{E}-1$ \\
\hline 074-S3-RS14 & $\mathrm{Bq}$ & $1.33 \mathrm{E}+7$ & $1.89 \mathrm{E}+5$ & $4.87 \mathrm{E}+6$ & $3.93 \mathrm{E}+6$ & $5.55 \mathrm{E}+7$ & $1.44 \mathrm{E}+5$ \\
\hline 074-S3-RS14 & $\mathrm{M} / \mathrm{A}$ & $8.66 \mathrm{E}-1$ & $9.00 \mathrm{E}-1$ & $9.69 \mathrm{E}-1$ & $9.64 \mathrm{E}-1$ & $9.59 \mathrm{E}-1$ & $9.86 \mathrm{E}-1$ \\
\hline 074-S3-RS14 & $\mathrm{M} / \mathrm{AA}$ & $8.98 \mathrm{E}-1$ & $9.34 \mathrm{E}-1$ & $1.01 \mathrm{E}+0$ & $1.00 \mathrm{E}+0$ & $9.95 \mathrm{E}-1$ & $1.02 \mathrm{E}+0$ \\
\hline 074-S3-RS14 & $\mathrm{M} / \mathrm{C}$ & $9.94 \mathrm{E}-1$ & $6.30 \mathrm{E}-1$ & $9.83 \mathrm{E}-1$ & $1.04 \mathrm{E}+0$ & $9.92 \mathrm{E}-1$ & $9.38 \mathrm{E}-1$ \\
\hline 074-S3-RS15 & $\mathrm{Bq}$ & $1.53 \mathrm{E}+7$ & $2.19 \mathrm{E}+5$ & $5.23 \mathrm{E}+6$ & $4.24 \mathrm{E}+6$ & $6.31 \mathrm{E}+7$ & $1.51 \mathrm{E}+5$ \\
\hline 074-S3-RS15 & $\mathrm{M} / \mathrm{A}$ & $9.98 \mathrm{E}-1$ & $1.04 \mathrm{E}+0$ & $1.04 \mathrm{E}+0$ & $1.04 \mathrm{E}+0$ & $1.09 \mathrm{E}+0$ & $1.04 \mathrm{E}+0$ \\
\hline 074-S3-RS15 & $\mathrm{M} / \mathrm{AA}$ & $9.59 \mathrm{E}-1$ & $1.00 \mathrm{E}+0$ & 9.99E-1 & $1.00 \mathrm{E}+0$ & $1.05 \mathrm{E}+0$ & $9.98 \mathrm{E}-1$ \\
\hline 074-S3-RS15 & $\mathrm{M} / \mathrm{C}$ & $1.06 \mathrm{E}+0$ & $6.75 \mathrm{E}-1$ & $9.77 \mathrm{E}-1$ & $1.04 \mathrm{E}+0$ & $1.05 \mathrm{E}+0$ & $9.15 \mathrm{E}-1$ \\
\hline
\end{tabular}


Appendix Table B-1 continued. Radionuclide inventories of particles from AGR-3/4 Compact 7-4

\begin{tabular}{lccccccc}
\hline Particle & Value & ${ }^{\mathbf{1 0 6}} \mathbf{R u}$ & ${ }^{\mathbf{1 2 5}} \mathbf{S b}$ & ${ }^{\mathbf{1 3 4}} \mathbf{C s}$ & ${ }^{137} \mathbf{C s}$ & ${ }^{\mathbf{1 4 4}} \mathbf{C e}$ & ${ }^{154} \mathbf{E u}$ \\
\hline Maximum & $\mathrm{Bq}$ & $1.97 \mathrm{E}+7$ & $2.66 \mathrm{E}+5$ & $6.09 \mathrm{E}+6$ & $5.06 \mathrm{E}+6$ & $6.97 \mathrm{E}+7$ & $1.74 \mathrm{E}+5$ \\
Maximum & $\mathrm{M} / \mathrm{A}$ & $8.54 \mathrm{E}-1$ & $8.61 \mathrm{E}-1$ & $8.41 \mathrm{E}-1$ & $8.58 \mathrm{E}-1$ & $8.25 \mathrm{E}-1$ & $7.16 \mathrm{E}-1$ \\
Maximum & $\mathrm{M} / \mathrm{AA}$ & $8.98 \mathrm{E}-1$ & $8.98 \mathrm{E}-1$ & $9.70 \mathrm{E}-1$ & $1.00 \mathrm{E}+0$ & $9.33 \mathrm{E}-1$ & $6.70 \mathrm{E}-1$ \\
Maximum & $\mathrm{M} / \mathrm{C}$ & $1.20 \mathrm{E}+0$ & $7.35 \mathrm{E}-1$ & $1.01 \mathrm{E}+0$ & $1.04 \mathrm{E}+0$ & $1.07 \mathrm{E}+0$ & $9.65 \mathrm{E}-1$ \\
Minimum & $\mathrm{Bq}$ & $1.33 \mathrm{E}+7$ & $1.70 \mathrm{E}+5$ & $4.12 \mathrm{E}+6$ & $3.35 \mathrm{E}+6$ & $4.77 \mathrm{E}+7$ & $1.04 \mathrm{E}+5$ \\
Minimum & $\mathrm{M} / \mathrm{A}$ & $9.91 \mathrm{E}-1$ & $9.96 \mathrm{E}-1$ & $9.97 \mathrm{E}-1$ & $9.97 \mathrm{E}-1$ & $9.94 \mathrm{E}-1$ & $9.98 \mathrm{E}-1$ \\
Minimum & $\mathrm{M} / \mathrm{AA}$ & $9.94 \mathrm{E}-1$ & $9.99 \mathrm{E}-1$ & $1.00 \mathrm{E}+0$ & $1.00 \mathrm{E}+0$ & $9.97 \mathrm{E}-1$ & $1.00 \mathrm{E}+0$ \\
Minimum & $\mathrm{M} / \mathrm{C}$ & $9.94 \mathrm{E}-1$ & $6.27 \mathrm{E}-1$ & $9.48 \mathrm{E}-1$ & $1.04 \mathrm{E}+0$ & $9.31 \mathrm{E}-1$ & $6.14 \mathrm{E}-1$ \\
Mean & $\mathrm{Bq}$ & $1.53 \mathrm{E}+7$ & $2.10 \mathrm{E}+5$ & $5.03 \mathrm{E}+6$ & $4.07 \mathrm{E}+6$ & $5.79 \mathrm{E}+7$ & $1.46 \mathrm{E}+5$ \\
Mean & $\mathrm{M} / \mathrm{A}$ & $8.30 \mathrm{E}-2$ & $8.19 \mathrm{E}-2$ & $7.34 \mathrm{E}-2$ & $6.90 \mathrm{E}-2$ & $7.65 \mathrm{E}-2$ & $7.38 \mathrm{E}-2$ \\
Mean & $\mathrm{M} / \mathrm{AA}$ & $4.13 \mathrm{E}-2$ & $4.40 \mathrm{E}-2$ & $1.76 \mathrm{E}-2$ & $0.00 \mathrm{E}+0$ & $3.37 \mathrm{E}-2$ & $5.98 \mathrm{E}-2$ \\
Mean & $\mathrm{M} / \mathrm{C}$ & $1.11 \mathrm{E}+0$ & $6.75 \mathrm{E}-1$ & $9.78 \mathrm{E}-1$ & $1.04 \mathrm{E}+0$ & $9.98 \mathrm{E}-1$ & $9.19 \mathrm{E}-1$ \\
SD & $\mathrm{Bq}$ & $9 \%$ & $9 \%$ & $8 \%$ & $8 \%$ & $8 \%$ & $8 \%$ \\
SD & $\mathrm{M} / \mathrm{A}$ & $0 \%$ & $0 \%$ & $0 \%$ & $0 \%$ & $0 \%$ & $0 \%$ \\
SD & $\mathrm{M} / \mathrm{AA}$ & $0 \%$ & $0 \%$ & $0 \%$ & $0 \%$ & $0 \%$ & $0 \%$ \\
SD & $\mathrm{M} / \mathrm{C}$ & $4 \%$ & $4 \%$ & $2 \%$ & $0 \%$ & $3 \%$ & $6 \%$ \\
\hline
\end{tabular}




\section{APPENDIX C. CALCULATED INVENTORIES}





\section{APPENDIX C: CALCULATED INVENTORIES 5}

The tables in this appendix provide the calculated inventories for select actinides and fission products (both radionuclides and stable nuclides) that were used to calculate values reported herein (i.e., compact fraction and $\mathrm{M} / \mathrm{C}$, as described in Section 0). Calculated inventories were estimated via physics depletion calculations using the Oak Ridge Isotope Generation and Depletion (ORIGEN2) code (Croff 1983, Ludwig and Croff 2002), the Monte Carlo N-Particle (MCNP) transport code (X-5 Monte Carlo Team 2003), and Jim Sterbentz's MCNP-ORIGEN2 coupled utility program (JMOCUP) and software extraction modules (Sterbentz 2015).

Appendix Table C-1. Calculated inventories of select actinides one year after EOL

\begin{tabular}{lcccccc}
\hline Compact & Value & ${ }^{235} \mathbf{U}$ & ${ }^{\mathbf{2 3 6}} \mathbf{U}$ & ${ }^{\mathbf{2 3 8}} \mathbf{U}$ & ${ }^{\mathbf{2 3 9}} \mathbf{P u}$ & ${ }^{\mathbf{2 4 0}} \mathbf{P u}$ \\
\hline AGR-3/4 8-4 & moles/compact & $1.0632 \mathrm{E}-04$ & $4.5510 \mathrm{E}-05$ & $1.4256 \mathrm{E}-03$ & $2.1690 \mathrm{E}-05$ & $8.4090 \mathrm{E}-06$ \\
AGR-3/4 8-4 & $\mu \mathrm{g} /$ compact & $2.4990 \mathrm{E}+04$ & $1.0742 \mathrm{E}+04$ & $3.3937 \mathrm{E}+05$ & $5.1850 \mathrm{E}+03$ & $2.0186 \mathrm{E}+03$ \\
AGR-3/4 7-4 & moles/compact & $9.9580 \mathrm{E}-05$ & $4.6380 \mathrm{E}-05$ & $1.4217 \mathrm{E}-03$ & $2.1640 \mathrm{E}-05$ & $8.5810 \mathrm{E}-06$ \\
AGR-3/4 7-4 & $\mu \mathrm{g} /$ compact & $2.3406 \mathrm{E}+04$ & $1.0948 \mathrm{E}+04$ & $3.3844 \mathrm{E}+05$ & $5.1731 \mathrm{E}+03$ & $2.0599 \mathrm{E}+03$ \\
\hline
\end{tabular}

Appendix Table C-2. Calculated inventories of select stable nuclides one year after EOL

\begin{tabular}{lcccccc}
\hline Compact & Value & ${ }^{105} \mathbf{P d}$ & ${ }^{\mathbf{1 0 9}} \mathbf{A g}$ & ${ }^{\mathbf{1 3 3}} \mathbf{C s}$ & ${ }^{\mathbf{1 3 9}} \mathbf{L a}$ & ${ }^{\mathbf{1 4 0}} \mathbf{C e}$ \\
\hline AGR-3/4 8-4 & moles/compact & $3.9170 \mathrm{E}-6$ & $6.9160 \mathrm{E}-7$ & $1.6644 \mathrm{E}-5$ & $1.7280 \mathrm{E}-5$ & $1.6851 \mathrm{E}-5$ \\
AGR-3/4 8-4 & $\mu \mathrm{g} /$ compact & $4.1091 \mathrm{E}+2$ & $7.5319 \mathrm{E}+1$ & $2.2121 \mathrm{E}+3$ & $2.4003 \mathrm{E}+3$ & $2.3575 \mathrm{E}+3$ \\
AGR-3/4 7-4 & moles/compact & $4.0710 \mathrm{E}-6$ & $7.3300 \mathrm{E}-7$ & $1.7094 \mathrm{E}-5$ & $1.7837 \mathrm{E}-5$ & $1.7417 \mathrm{E}-5$ \\
AGR-3/4 7-4 & $\mu \mathrm{g} /$ compact & $4.2707 \mathrm{E}+2$ & $7.9827 \mathrm{E}+1$ & $2.2719 \mathrm{E}+3$ & $2.4777 \mathrm{E}+3$ & $2.4367 \mathrm{E}+3$ \\
\hline
\end{tabular}

Appendix Table C-2 continued. Calculated inventories of select stable nuclides one year after EOL

\begin{tabular}{lcccccc}
\hline Compact & Value & ${ }^{141} \mathbf{P r}$ & ${ }^{\mathbf{1 4 6} N d}$ & ${ }^{\mathbf{1 5 2}} \mathbf{S m}$ & ${ }^{\mathbf{1 5 3}} \mathbf{E u}$ & ${ }^{\mathbf{1 5 6}} \mathbf{G d}$ \\
\hline AGR-3/4 8-4 & moles/compact & $1.5599 \mathrm{E}-5$ & $1.0235 \mathrm{E}-5$ & $1.4414 \mathrm{E}-6$ & $1.1848 \mathrm{E}-6$ & $5.2810 \mathrm{E}-7$ \\
AGR-3/4 8-4 & $\mu \mathrm{g} /$ compact & $2.1980 \mathrm{E}+3$ & $1.4934 \mathrm{E}+3$ & $2.1898 \mathrm{E}+2$ & $1.8118 \mathrm{E}+2$ & $8.2342 \mathrm{E}+1$ \\
AGR-3/4 7-4 & moles/compact & $1.6100 \mathrm{E}-5$ & $1.0621 \mathrm{E}-5$ & $1.4790 \mathrm{E}-6$ & $1.2448 \mathrm{E}-6$ & $5.8160 \mathrm{E}-7$ \\
AGR-3/4 7-4 & $\mu \mathrm{g} /$ compact & $2.2686 \mathrm{E}+3$ & $1.5497 \mathrm{E}+3$ & $2.2469 \mathrm{E}+2$ & $1.9036 \mathrm{E}+2$ & $9.0684 \mathrm{E}+1$ \\
\hline
\end{tabular}

${ }^{5}$ This appendix is a revised version of a similar appendix in a previous AGR-3/4 PIE report (Hunn and Montgomery, 2020) and is duplicated herein to maintain a consistent format in documenting similar data. 
Appendix Table C-3. Calculated inventories of select radionuclides one day after EOL

\begin{tabular}{lcccccc}
\hline Compact & Value & ${ }^{\mathbf{8 5}} \mathbf{K r}$ & ${ }^{\mathbf{9}} \mathbf{S r}$ & ${ }^{\mathbf{1 0}} \mathbf{R u}$ & ${ }^{\mathbf{1 1 0} \mathbf{m}} \mathbf{A g}$ & ${ }^{\mathbf{1 2 5}} \mathbf{S b}$ \\
\hline AGR-3/4 8-4 & moles/compact & $6.2280 \mathrm{E}-07$ & $1.3542 \mathrm{E}-05$ & $1.9235 \mathrm{E}-06$ & $5.3730 \mathrm{E}-09$ & $1.1966 \mathrm{E}-07$ \\
AGR-3/4 8-4 & Bq/compact & $7.6592 \mathrm{E}+08$ & $6.2219 \mathrm{E}+09$ & $2.4995 \mathrm{E}+10$ & $1.0393 \mathrm{E}+08$ & $5.7379 \mathrm{E}+08$ \\
AGR-3/4 8-4 & Bq/particle & $3.9933 \mathrm{E}+05$ & $3.2440 \mathrm{E}+06$ & $1.3032 \mathrm{E}+07$ & $5.4189 \mathrm{E}+04$ & $2.9916 \mathrm{E}+05$ \\
AGR-3/4 7-4 & moles/compact & $6.4100 \mathrm{E}-07$ & $1.3930 \mathrm{E}-05$ & $2.0450 \mathrm{E}-06$ & $5.9910 \mathrm{E}-09$ & $1.2468 \mathrm{E}-07$ \\
AGR-3/4 7-4 & Bq/compact & $7.8830 \mathrm{E}+08$ & $6.4002 \mathrm{E}+09$ & $2.6573 \mathrm{E}+10$ & $1.1589 \mathrm{E}+08$ & $5.9786 \mathrm{E}+08$ \\
AGR-3/4 7-4 & Bq/particle & $4.1100 \mathrm{E}+05$ & $3.3369 \mathrm{E}+06$ & $1.3855 \mathrm{E}+07$ & $6.0421 \mathrm{E}+04$ & $3.1171 \mathrm{E}+05$ \\
\hline
\end{tabular}

Appendix Table C-3 continued. Calculated inventories of select radionuclides one day after EOL

\begin{tabular}{lcccccc}
\hline Compact & Value & ${ }^{\mathbf{1 3 4}} \mathbf{C s}$ & ${ }^{\mathbf{1 3 7}} \mathbf{C s}$ & ${ }^{\mathbf{1 4 4}} \mathbf{C e}$ & ${ }^{\mathbf{1 5 4}} \mathbf{E u}$ & ${ }^{\mathbf{1 5 5}} \mathbf{E u}$ \\
\hline AGR-3/4 8-4 & moles/compact & $1.4211 \mathrm{E}-06$ & $1.6474 \mathrm{E}-05$ & $6.3670 \mathrm{E}-06$ & $1.8683 \mathrm{E}-07$ & $6.8130 \mathrm{E}-08$ \\
AGR-3/4 8-4 & Bq/compact & $9.1022 \mathrm{E}+09$ & $7.2445 \mathrm{E}+09$ & $1.0797 \mathrm{E}+11$ & $2.8733 \mathrm{E}+08$ & $1.8961 \mathrm{E}+08$ \\
AGR-3/4 8-4 & Bq/particle & $4.7457 \mathrm{E}+06$ & $3.7771 \mathrm{E}+06$ & $5.6291 \mathrm{E}+07$ & $1.4981 \mathrm{E}+05$ & $9.8857 \mathrm{E}+04$ \\
AGR-3/4 7-4 & moles/compact & $1.5404 \mathrm{E}-06$ & $1.7035 \mathrm{E}-05$ & $6.5590 \mathrm{E}-06$ & $1.9809 \mathrm{E}-07$ & $7.2240 \mathrm{E}-08$ \\
AGR-3/4 7-4 & Bq/compact & $9.8663 \mathrm{E}+09$ & $7.4912 \mathrm{E}+09$ & $1.1122 \mathrm{E}+11$ & $3.0465 \mathrm{E}+08$ & $2.0105 \mathrm{E}+08$ \\
AGR-3/4 7-4 & Bq/particle & $5.1441 \mathrm{E}+06$ & $3.9057 \mathrm{E}+06$ & $5.7989 \mathrm{E}+07$ & $1.5884 \mathrm{E}+05$ & $1.0482 \mathrm{E}+05$ \\
\hline
\end{tabular}




$$
\text { C-3 }
$$


APPENDIX D. SPECIAL DECONSOLIDATION APPARATUS 



\section{APPENDIX D: SPECIAL DECONSOLIDATION APPARATUS}

The diagram in this appendix shows the special deconsolidation apparatus which was fabricated and used for the deconsolidation of the large residual section of AGR-3/4 Compact 7-4 which broke away from the mounting axle during the third radial deconsolidation section. The apparatus was designed to maintain current through the compact while partially submerging it in nitric acid to continue the electrolytic deconsolidation. Details of this process are provided in Section 4.1.
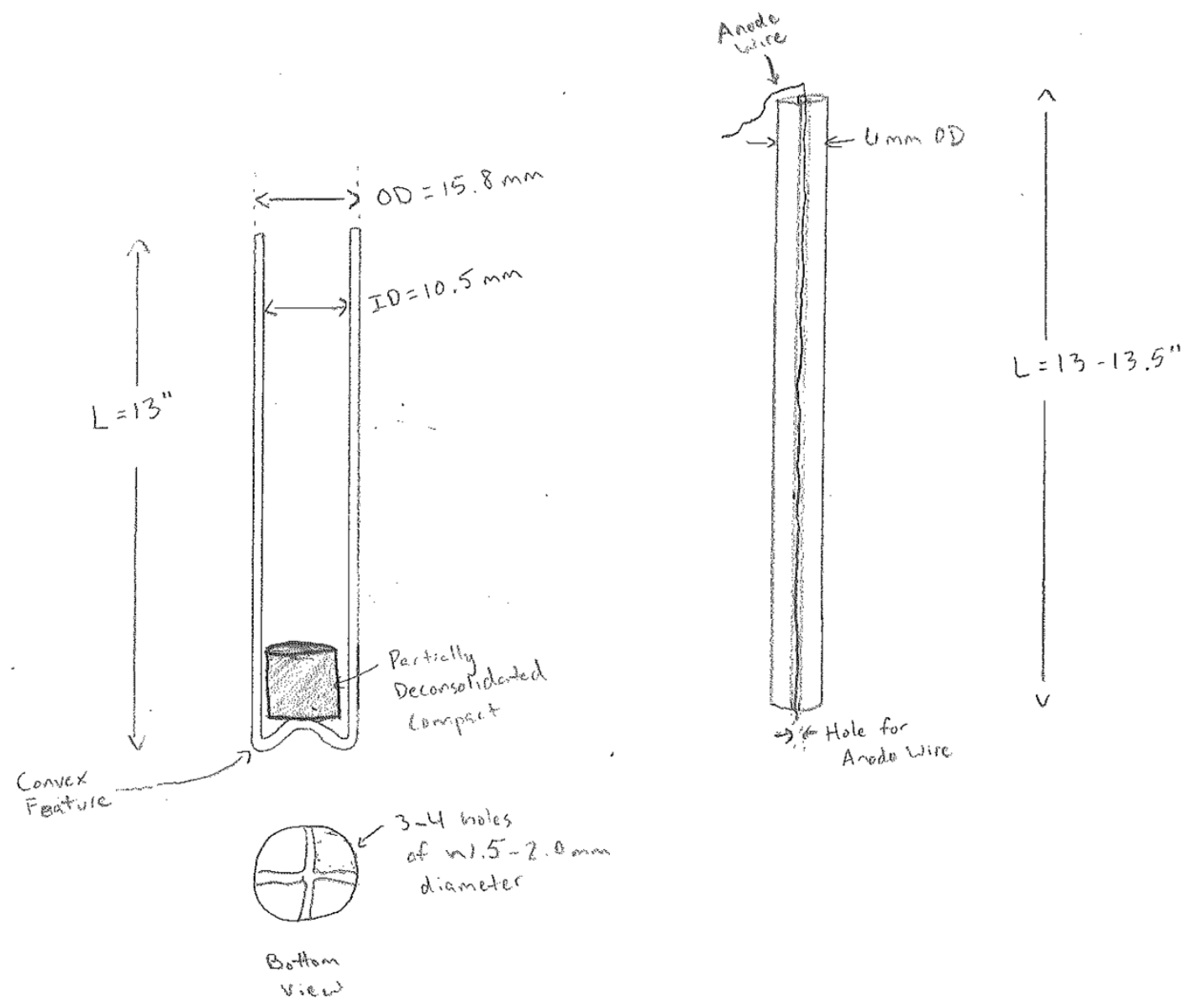